\section{Pacific Northwest}

National Laboratory

Operated by Battelle for the

U.S. Department of Energy

\title{
Impact of 2004 Office of Energy Efficiency and Renewable Energy Buildings-Related Projects on United States Employment and Earned Income
}

\author{
M. Scott \\ D. Anderson \\ D. Belzer \\ K. Cort \\ J. Dirks \\ D. Elliott \\ D. Hostick
}

April 2003

Prepared for the U.S. Department of Energy under Contract DE-AC06-76RL01830 


\title{
DISCLAIMER
}

This report was prepared as an account of work sponsored by an agency of the United States Government. Neither the United States Government nor any agency thereof, nor Battelle Memorial Institute, nor any of their employees, makes any warranty, express or implied, or assumes any legal liability or responsibility for the accuracy, completeness, or usefulness of any information, apparatus, product, or process disclosed, or represents that its use would not infringe privately owned rights. Reference herein to any specific commercial product, process, or service by trade name, trademark, manufacturer, or otherwise does not necessarily constitute or imply its endorsement, recommendation, or favoring by the United States Government or any agency thereof, or Battelle Memorial Institute. The views and opinions of authors expressed herein do not necessarily state or reflect those of the United States Government or any agency thereof.

\author{
PACIFIC NORTHWEST NATIONAL LABORATORY \\ operated by \\ BATTELLE \\ for the \\ UNITED STATES DEPARTMENT OF ENERGY \\ under Contract DE-AC06-76RL01830
}




\section{Impact of 2004 Office of Energy Efficiency and Renewable Energy Buildings-Related Projects on United States Employment and Earned Income}

April 2003

Prepared for

the U.S. Department of Energy

under Contract DE-AC06-76RL01830

Pacific Northwest National Laboratory

Richland, Washington 99352 



\begin{abstract}
The Department of Energy (DOE) Office of Energy Efficiency and Renewable Energy (EERE) is interested in assessing the potential economic impacts of its portfolio of projects on national employment and income. A special purpose version of the IMPLAN input-output model called ImBuild II is used in this study of all 37 buildings-related projects reported to the Office of Management and Budget on February 3, 2003 for inclusion in the revised fiscal year (FY) 2004 budget request. Energy savings, investments, and impacts on U.S. national employment and earned income are reported by project for selected years to the year 2030. Energy savings and investments from these projects have the potential of creating a total of 297,000 jobs and about $\$ 4.16$ billion in earned income (2002\$) by the year 2030 .
\end{abstract}





\section{Summary}

As part of measuring the impact of government projects for improving the energy efficiency of the nation's building stock, the Department of Energy (DOE) Office of Energy Efficiency and Renewable Energy (EERE) is interested in assessing the economic impacts of its portfolio of projects, specifically the potential impact on national employment and income. This assessment was done for the first time in FY 1999 as a supplement to the Government Performance and Results Act (GPRA-formerly, Quality Metrics) analysis for EERE. The GPRA analysis provides estimates of primary energy savings and environmental and direct financial benefits of the 37 EERE projects related to the buildings sector. The current analysis performs this assessment on the FY2004 budget request from EERE.

The programmatic needs of EERE suggest that a simple, flexible, user-friendly method is needed to derive national employment and income impacts of individual EERE projects. Therefore, EERE funded Pacific Northwest National Laboratory (PNNL) to develop a special-purpose national input-output model called ImBuild, the latest version of which is ImBuild II (Scott et al. 2002). In this report, we use the ImBuild II model to calculate the impact of all 37 EERE projects related to the buildings sector, based on the final Weatherization and Integovernmental Activities budget and Building Technologies Program budget submitted February 3, 2003.

EERE projects affect the economy through three primary mechanisms. First, if the incremental capital costs of the new technology per installed unit are different from those of the conventional technology, the level of purchases will change in the sectors involved in manufacturing, distribution, and installation for both technologies, changing the level of overall economic activity. Second, the efficiency investment may crowd out other domestic saving, investments, and consumer spending, offsetting some positive impact on the economy caused by the new efficiency investment. Third, energy and non-energy expenditures are reduced. On the one hand, this saving reduces final sales in the electric and gas utility sectors, as well as in the trade and services sectors that provide related maintenance, parts, and services. But, on the other hand, it increases net disposable income of households and businesses and increases general consumer and business spending in all sectors (including some increases in expenditures for electric and gas utility services and retail trade and services).

Energy efficient technology is expected to have a measurable effect on the activity level of the U.S. economy. EERE projects are characterized by significant investment requirements and delivered energy cost savings. Due to reorganization of the Office of Energy Efficiency and Renewable Energy that occurred during the year 2002, the EERE projects related to buildings have been gathered into two groupings. The first, the Weatherization and Intergovernmental Program, is a group of projects mostly focused on implementing currently available efficient technology and overcoming market barriers. It consists of three decision units: Weatherization Assistance, all State Formula Grants projects, and Gateway Deployment. The latter consists of Energy Star (which is actually a group of seven specific technology projects), Rebuild America, Information Outreach, and Training and Technical Assistance. The impacts of the Weatherization and Intergovernmental Program are summarized in Figure S.1 and 
Table S.1. ${ }^{\text {(a) }}$ Figure S.1 and Table S.1 show the energy savings expected to be created by market penetration of these projects have the potential of creating nearly 133,000 jobs and about $\$ 1.61$ billion in earned income (2002\$) by the year 2030. However, the net gains would be affected by the intensive investment in new energy technology and new building practices would be required during the first 30 years of the 21 st century. These effects are incorporated in the full investment scenario shown in the lower half of Table S.1. Because the Weatherization and Intergovernmental Program investment tends to be concentrated in capital-intensive, high-wage industries, there is a slight net negative impact on employment and positive impact on earnings from this group of investments. Many of the capital investments required to achieve these savings begin early in the 30 -year period.

To be in concert with a recent analysis of the Department of Energy's Energy Research and Development program by the National Research Council (NRC) of the National Academy of Sciences, the analysis in some cases only takes credit for the first three to ten years of market impact. The NRC used a simplifying assumption that government $\mathrm{R} \& \mathrm{D}$ programs do no more than accelerate the technology; bringing it to market five years before the private sector would have without government intervention. The net effect of this assumption is that incremental investments due to the EERE projects are overtaken by "normal" investments, which would limit both the savings and investments due to the EERE projects. However, the more complete analysis of EERE projects performed for this report shows that the impacts on investment and energy savings result from the interaction of four factors: 1) the size of the (usually growing) market at each point in time, 2) the penetration rate for the EERE technologies and practices, based on lifetime cost savings vis-à-vis conventional technology and the associated payback period for the investment, 3) increases in the efficiency of dollar of incremental investment, based in turn on the sales-volume based rate of decline in the price of the technology and the higher durability of the EERE technology, and 4) the market-transformation, crowding-out effects of one technology on market prospects of all of its potential competitors. This results in a "hill-like" pattern of project-related efficiency investments shown in the upper left-hand panel of Figure S.1, and in Table S.1

(a) In this analysis, we used project information from Anderson et al. (2003) that PNNL prepared with DOE/EERE project managers. Delivered energy is used to calculate potential savings resulting from reduced demand for electrical generating capacity and natural gas pipeline capacity. See Scott et al. (2002). 
Table S.1. Impact of the Weatherization and Intergovernmental Program on the U.S. Economy

\begin{tabular}{|c|c|c|c|c|}
\hline \multicolumn{2}{|c|}{$\begin{array}{l}\text { Incremental Investment Cost } \\
\text { (Million 2002\$) }\end{array}$} & $\begin{array}{c}\text { Delivered } \\
\text { Energy Saved } \\
\left(\mathbf{1 0}^{12} \text { Btu }\right)\end{array}$ & $\begin{array}{l}\text { Potential } \\
\text { Jobs } \\
\text { Created } \\
\text { (Thousand) }\end{array}$ & $\begin{array}{c}\text { Impact on } \\
\text { National } \\
\text { Earnings } \\
\text { (Million } \\
\text { 2002\$) }\end{array}$ \\
\hline \multicolumn{5}{|c|}{ Impact of Energy Savings Alone } \\
\hline 2004 & 0 & 30 & 5 & $\$ 49$ \\
\hline 2005 & 0 & 55 & 6 & $\$ 68$ \\
\hline 2006 & 0 & 83 & 9 & $\$ 105$ \\
\hline 2007 & 0 & 105 & 11 & $\$ 134$ \\
\hline 2008 & 0 & 132 & 15 & $\$ 171$ \\
\hline 2010 & 0 & 198 & 24 & $\$ 272$ \\
\hline 2015 & 0 & 412 & 56 & $\$ 667$ \\
\hline 2020 & 0 & 629 & 94 & $\$ 1,133$ \\
\hline 2025 & 0 & 764 & 118 & $\$ 1,425$ \\
\hline 2030 & 0 & 862 & 133 & $\$ 1,607$ \\
\hline \multicolumn{5}{|c|}{ Impact of Full Investment Scenario } \\
\hline 2004 & $\$ 1,967$ & 30 & 3 & $\$ 154$ \\
\hline 2005 & $\$ 2,372$ & 55 & 4 & $\$ 193$ \\
\hline 2006 & $\$ 2,637$ & 83 & 7 & $\$ 245$ \\
\hline 2007 & $\$ 2,919$ & 105 & 10 & $\$ 291$ \\
\hline 2008 & $\$ 3,031$ & 132 & 13 & $\$ 334$ \\
\hline 2010 & $\$ 3,689$ & 198 & 22 & $\$ 474$ \\
\hline 2015 & $\$ 3,565$ & 412 & 54 & $\$ 857$ \\
\hline 2020 & $\$ 3,026$ & 629 & 93 & $\$ 1,296$ \\
\hline 2025 & $\$ 2,083$ & 764 & 117 & $\$ 1,542$ \\
\hline 2030 & $\$ 1,272$ & 862 & 133 & $\$ 1,687$ \\
\hline
\end{tabular}



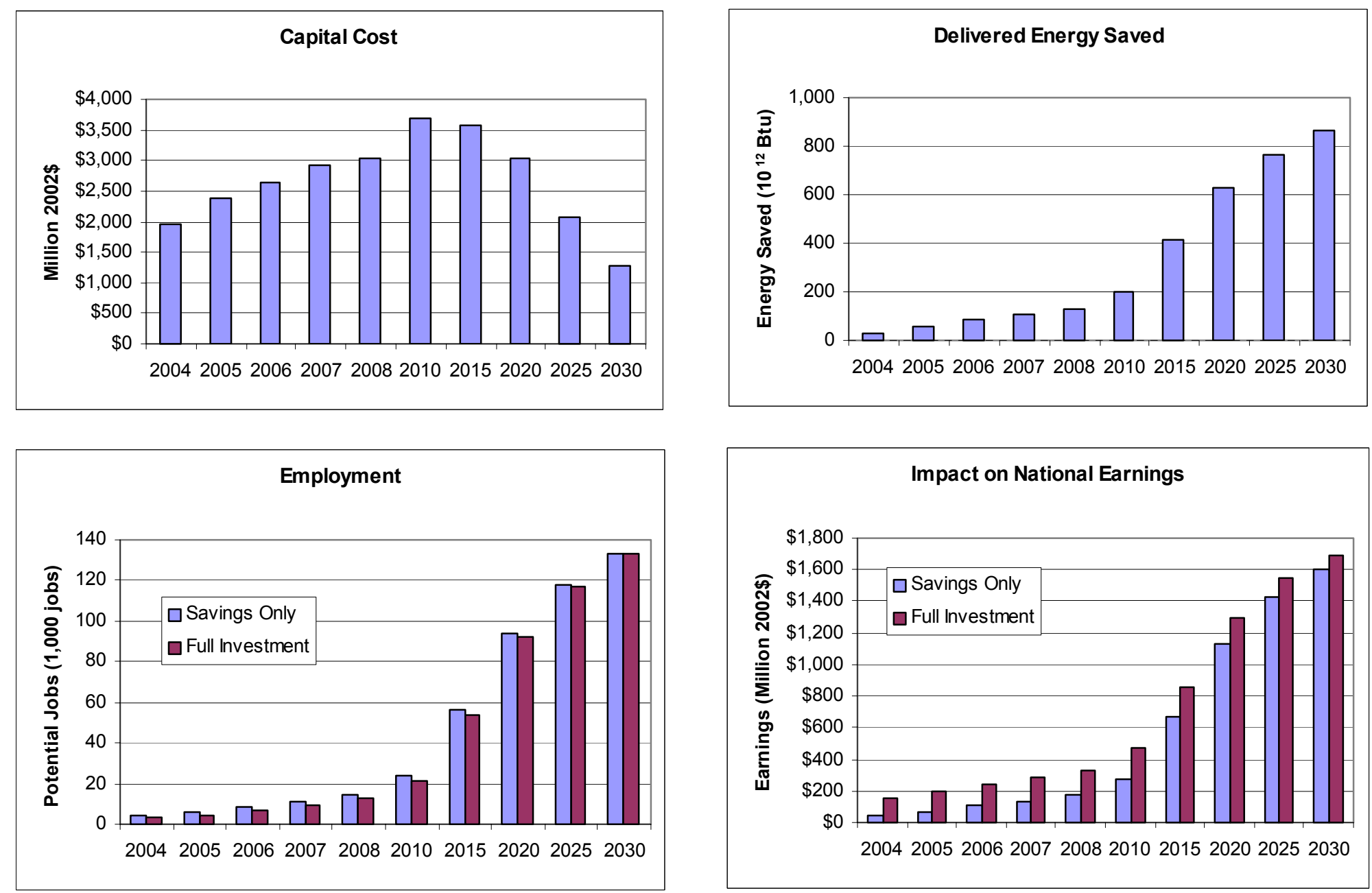

Figure S.1. Impact of the Weatherization and Intergovernmental Program on the U.S. Economy 
The rest of the EERE buildings-related projects are grouped together under the Building Technologies Program. As the name suggests, this is a group of projects that is focused on advancing the development of new technologies and analysis techniques for the building sector. It comprises Residential Buildings Integration, Commercial Buildings Integration, Emerging Technologies (in lighting, refrigeration, appliances, windows, and insulation), and Equipment Standards and Analysis decision units. The impacts of the Building Technologies Program are summarized in Figure S.2 and Table S.2. The energy savings associated with these projects have the potential of creating nearly 172,000 jobs and about $\$ 2.18$ billion in earned income (2002\$) by the year 2030. Not all of the gains would be immediately apparent because intensive investment in new energy technology and new building practices would be required during the first 30 years of the $21^{\text {st }}$ century. Because the Buildings Technologies project investments tend to be concentrated in capital-intensive, high-wage industries, there is a slight net negative impact on employment and positive impact on earnings from this group of investments.

Table S.2. Impact of the Building Technologies Program on the U.S. Economy

\begin{tabular}{|c|c|c|c|c|}
\hline \multicolumn{2}{|c|}{$\begin{array}{l}\text { Incremental Investment Cost } \\
\text { (Million 2002\$) }\end{array}$} & $\begin{array}{c}\text { Delivered } \\
\text { Energy Saved } \\
\left(\mathbf{1 0}^{12} \text { Btu }\right)\end{array}$ & $\begin{array}{l}\text { Potential } \\
\text { Jobs } \\
\text { Created } \\
\text { (Thousands) }\end{array}$ & $\begin{array}{c}\text { Impact on National } \\
\text { Earnings } \\
\text { (Million 2002\$) }\end{array}$ \\
\hline \multicolumn{5}{|c|}{ Impact of Energy Savings Alone } \\
\hline 2004 & 0 & 9 & 2 & $\$ 21$ \\
\hline 2005 & 0 & 20 & 3 & $\$ 33$ \\
\hline 2006 & 0 & 36 & 5 & $\$ 55$ \\
\hline 2007 & 0 & 55 & 7 & $\$ 82$ \\
\hline 2008 & 0 & 89 & 11 & $\$ 140$ \\
\hline 2010 & 0 & 190 & 23 & $\$ 282$ \\
\hline 2015 & 0 & 565 & 63 & $\$ 773$ \\
\hline 2020 & 0 & 943 & 112 & $\$ 1,424$ \\
\hline 2025 & 0 & 1,208 & 146 & $\$ 1,855$ \\
\hline 2030 & 0 & 1,469 & 172 & $\$ 2,182$ \\
\hline \multicolumn{5}{|c|}{ Impact of Full Investment Scenario } \\
\hline 2004 & $\$ 846$ & 9 & 1 & $\$ 63$ \\
\hline 2005 & $\$ 1,260$ & 20 & 1 & $\$ 97$ \\
\hline 2006 & $\$ 1,580$ & 36 & 3 & $\$ 136$ \\
\hline 2007 & $\$ 1,891$ & 55 & 5 & $\$ 179$ \\
\hline 2008 & $\$ 3,195$ & 89 & 6 & $\$ 283$ \\
\hline 2010 & $\$ 4,389$ & 190 & 17 & $\$ 489$ \\
\hline
\end{tabular}




\begin{tabular}{|c|c|c|c|c||}
\hline \multicolumn{2}{|c|}{$\begin{array}{c}\text { Incremental Investment Cost } \\
\text { (Million 2002\$) }\end{array}$} & $\begin{array}{c}\text { Delivered } \\
\text { Energy Saved } \\
\left(\mathbf{1 0}^{12} \text { Btu) }\right.\end{array}$ & $\begin{array}{c}\text { Potential } \\
\text { Jobs } \\
\text { Created } \\
\text { (Thousands) }\end{array}$ & $\begin{array}{c}\text { Impact on National } \\
\text { Earnings } \\
\text { (Million 2002\$) }\end{array}$ \\
\hline 2015 & $\$ 6,415$ & 565 & 54 & $\$ 1,083$ \\
\hline 2020 & $\$ 5,737$ & 943 & 103 & $\$ 1,677$ \\
\hline 2025 & $\$ 5,678$ & 1,208 & 138 & $\$ 2,127$ \\
\hline 2030 & $\$ 6,094$ & 1,469 & 164 & $\$ 2,475$ \\
\hline
\end{tabular}



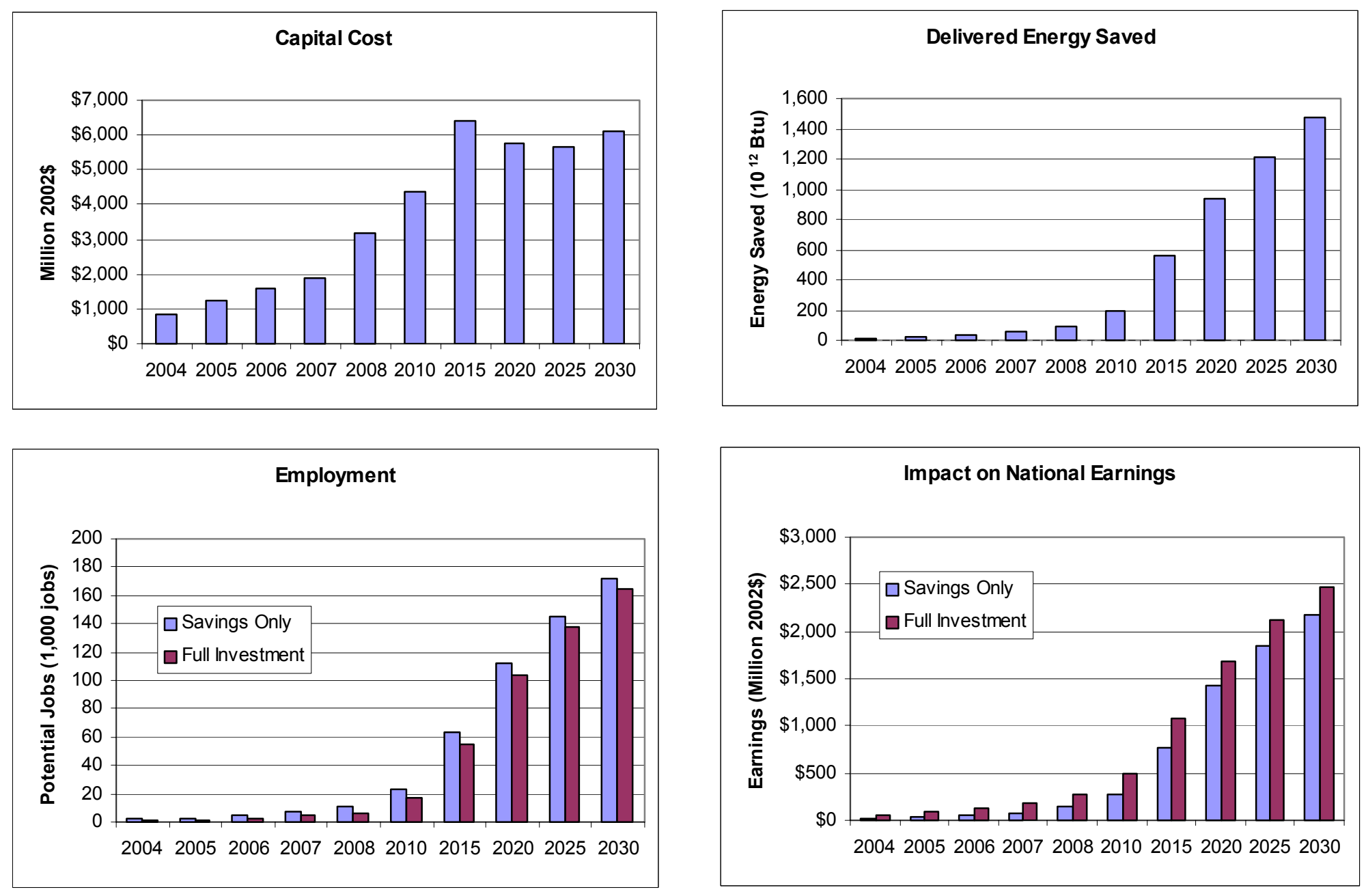

Figure S.2. Impact of the Building Technologies Program on the U.S. Economy 
Figure S.3 and Table S.3 show that the energy savings expected to be created by market penetration of all of the EERE buildings-related projects, taken together, have the potential of creating nearly 305,000 jobs and about $\$ 4.16$ billion in earned income (2002\$) by the year 2030. Again, not all of the gains would be immediately apparent because intensive investment in new energy technology and new building practices would be required during the first 30 years of the $21^{\text {st }}$ century. These effects are incorporated in the full investment scenario shown in the lower half of Table S.3. For the most part, this incremental investment in energy technology, contrary to its popular image, is likely to be more capital-intensive than the average consumption and investment in the economy. This difference is due to the fact that most of the increment to investment occurs in capital-intensive manufacturing processes. Because we assume the capital required to make the energy efficiency investments is diverted proportionately from all competing uses for money in the economy (a large proportion of which is personal and business consumption of laborintensive goods and services such as groceries, clothing, travel services, or personal and business services), the investments reduce the employment level in the short run.

Only when the energy benefits of cumulative efficiency investments have grown large, relative to the costs of current investment, would the full impacts on employment and income become visible. Thus, in the full investment scenario, as the energy technologies and practices associated with the 37 EERE buildings-related projects penetrate the U.S. marketplace over the next 30 years, the required capital investments are significant and increasing over most of the period, reaching a peak of about $\$ 10$ billion per year in 2015. These required investments divert national spending into capital-intensive sectors and initially reduce employment below what it otherwise would have been. However, the energy savings associated with these same investments ( 2 quads per year by the year 2030, worth over $\$ 38$ billion) are true economic savings that provide new economic opportunities, generate ever-increasing numbers of jobs and higher income, and eventually become the dominant economic result of the EERE projects.

More than half of the net jobs (57\%) and net earned income benefits (56\%) of the 37 projects come from only six of the projects: Building Codes Training and Technical Assistance, Energy Star CFLs, Commercial Building Energy Codes, Next Generation Lighting Initiative, Window Technologies' Superwindows, and EPACT Standards. These six projects are large-scale, cost-effective projects that are expected to produce large energy savings relative to the investments required. By the year 2030, five out of six of these projects each will produce net annual savings to the U.S. economy (after investment costs) over $\$ 1.3$ billion per year (about $\$ 18$ billion together) and 183,000 net total jobs (after investment effects). If the Energy Star projects and Emerging Technologies projects are counted as single projects, they account for net savings impacts of $\$ 8.5$ billion and $\$ 7.6$ billion, respectively, and have a combined positive impact of 164,000 net total jobs. The impacts of most of the other EERE buildings-related projects are on a much smaller scale. 
Table S.3. Impact of 37 EERE Buildings-Related Projects on the U.S. Economy

\begin{tabular}{|c|c|c|c|c|}
\hline $\begin{array}{r}\text { Incre } \\
\text { Cos }\end{array}$ & $\begin{array}{l}\text { Investment } \\
\text { on 2002\$) }\end{array}$ & $\begin{array}{l}\text { Delivered } \\
\text { Energy } \\
\text { Saved }\left(10^{12}\right. \\
\text { Btu) }\end{array}$ & $\begin{array}{c}\text { Potential } \\
\text { Jobs } \\
\text { Created } \\
\text { (Thousands) }\end{array}$ & $\begin{array}{c}\text { Impact on National } \\
\text { Earnings (Million } \\
2002 \$)\end{array}$ \\
\hline Impact & gy Savings $A$ & & & \\
\hline 2004 & 0 & 39 & 7 & $\$ 70$ \\
\hline 2005 & 0 & 75 & 8 & $\$ 101$ \\
\hline 2006 & 0 & 118 & 13 & $\$ 160$ \\
\hline 2007 & 0 & 161 & 18 & $\$ 216$ \\
\hline 2008 & 0 & 221 & 26 & $\$ 311$ \\
\hline 2010 & 0 & 387 & 47 & $\$ 555$ \\
\hline 2015 & 0 & 976 & 120 & $\$ 1,441$ \\
\hline 2020 & 0 & 1,572 & 207 & $\$ 2,557$ \\
\hline 2025 & 0 & 1,973 & 263 & $\$ 3,280$ \\
\hline 2030 & 0 & 2,331 & 305 & $\$ 3,789$ \\
\hline Impact & Investment S & ario & & \\
\hline 2004 & $\$ 2,813$ & 39 & 4 & $\$ 217$ \\
\hline 2005 & $\$ 3,632$ & 75 & 5 & $\$ 290$ \\
\hline 2006 & $\$ 4,217$ & 118 & 10 & $\$ 381$ \\
\hline 2007 & $\$ 4,810$ & 161 & 14 & $\$ 469$ \\
\hline 2008 & $\$ 6,226$ & 221 & 19 & $\$ 616$ \\
\hline 2010 & $\$ 8,077$ & 387 & 38 & $\$ 962$ \\
\hline 2015 & $\$ 9,980$ & 976 & 109 & $\$ 1,940$ \\
\hline 2020 & $\$ 8,763$ & 1,572 & 196 & $\$ 2,973$ \\
\hline 2025 & $\$ 7,761$ & 1,973 & 255 & $\$ 3,669$ \\
\hline 2030 & $\$ 7,366$ & 2,331 & 297 & $\$ 4,162$ \\
\hline
\end{tabular}



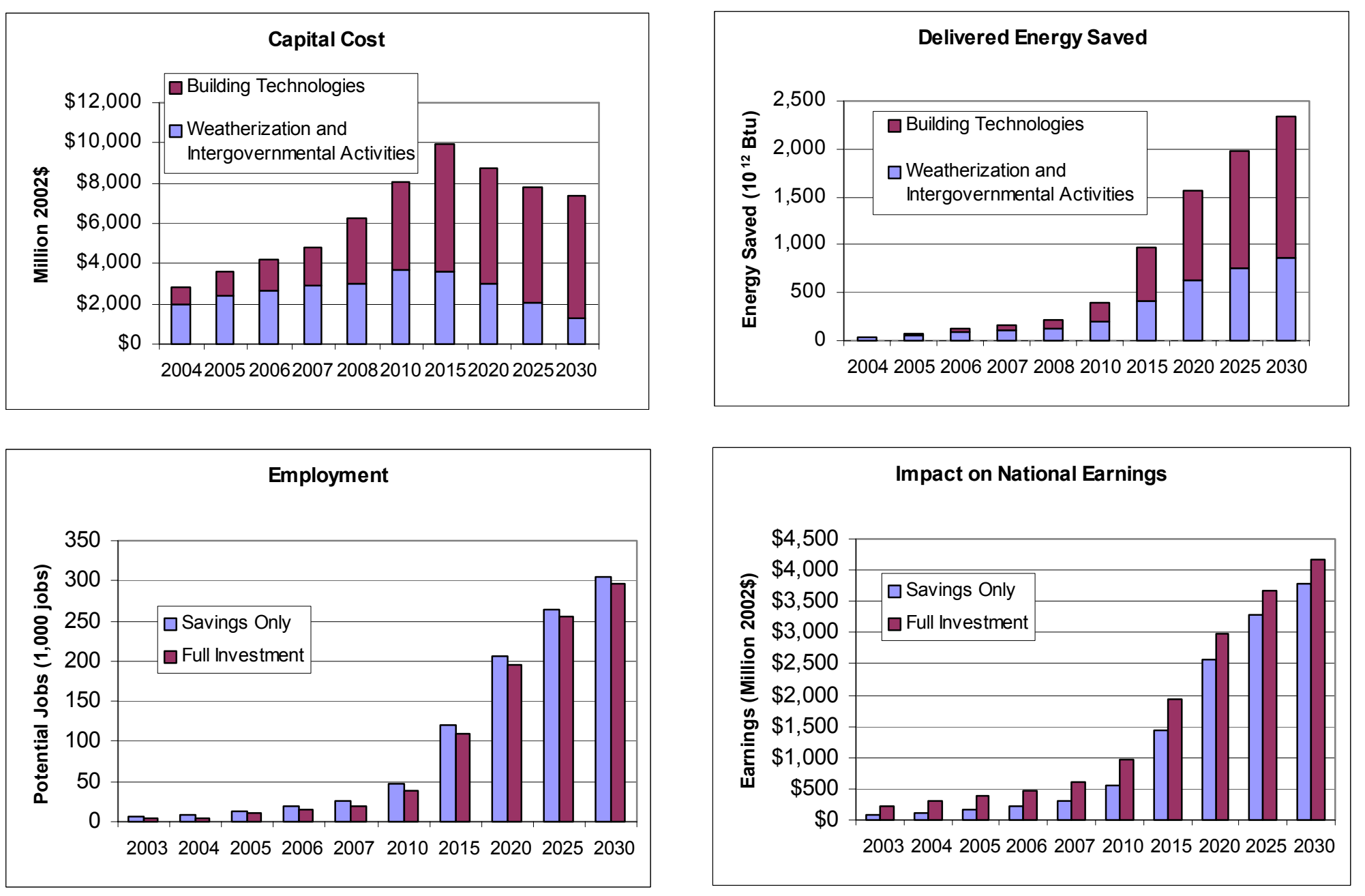

Figure S.3. Impact of 37 EERE Buildings-Related Projects on the U.S. Economy 


\section{Acknowledgments}

The authors would like to acknowledge John Sullivan, Deputy Assistant Secretary for Business Administration, and Sam Baldwin, Director, and Jerry Dion, Management and Program Analyst, of the Department of Energy Office of Planning, Budget Formulation and Analysis, for support of the work discussed in this report. We would also like to acknowledge the assistance of several colleagues who reviewed and commented on the methodology and this report: A. K. Nicholls, S. C. McDonald, J. M. Roop, S. A. Shankle. 



\section{Acronyms}

\section{Term}

$\mathrm{AC}$

CFL

DOE

EERE

EIA

FY

GDP

GPRA

HVAC

ImBuild

IMPLAN

NAS

NRC

PNNL

$R \& D$

RIMS II

SIC

\section{Definition}

Air conditioning

Compact fluorescent lamp

Department of Energy

Office of Energy Efficiency and Renewable Energy

Energy Information Administration

Fiscal year

Gross Domestic Product

Government Performance and Results Act (formerly, Quality Metrics)

Heating, Ventilating and Air Conditioning

Special purpose version of IMPLAN (PNNL)

Impact Analysis for Planning

National Academy of Sciences

National Research Council

Pacific Northwest National Laboratory

Research and Development

Regional Input-Output Modeling System

Standard Industrial Classification

xvii 



\section{Contents}

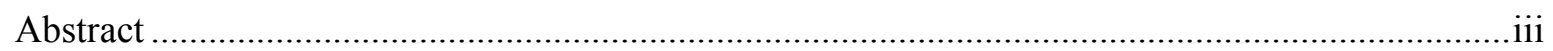

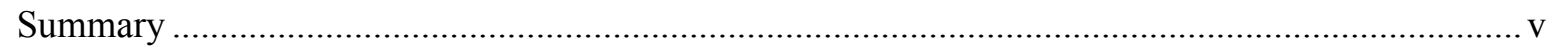

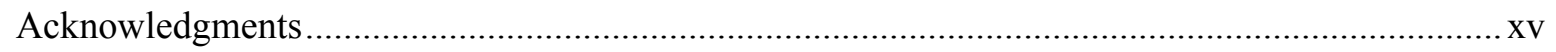

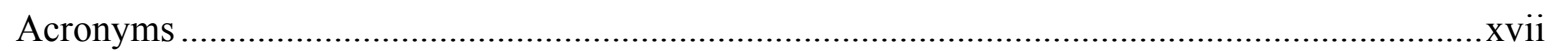

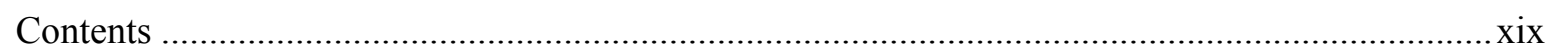

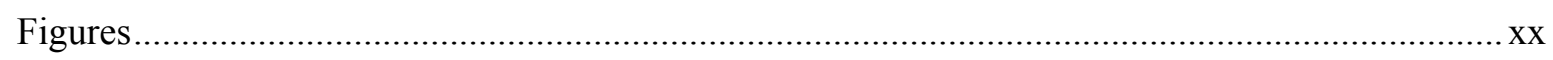

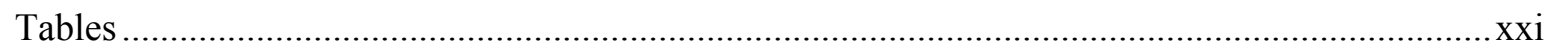

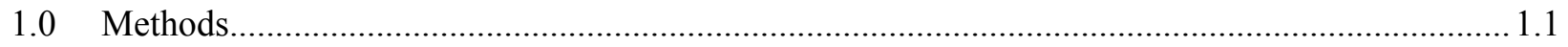

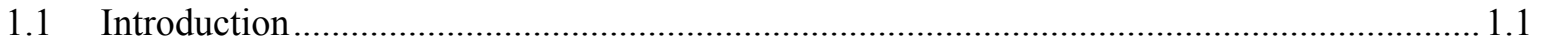

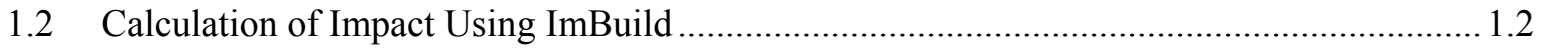

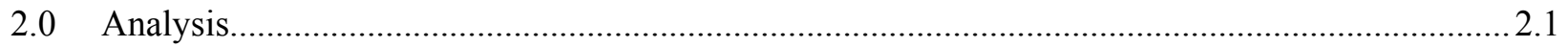

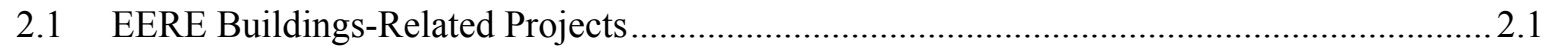

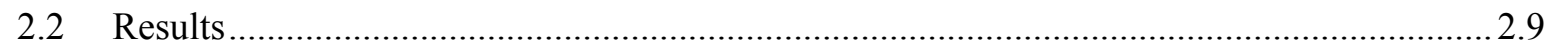

2.2.1 Weatherization and Intergovernmental Program ........................................... 2.10

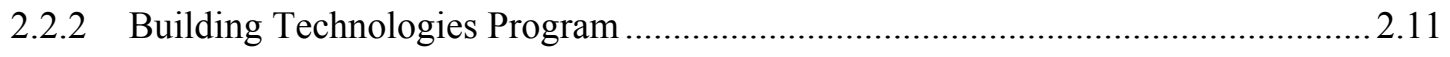

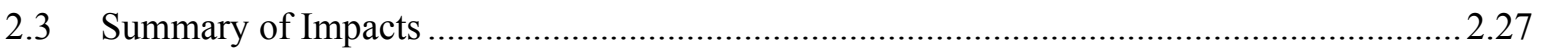

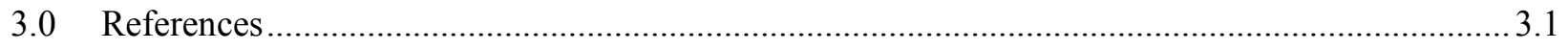

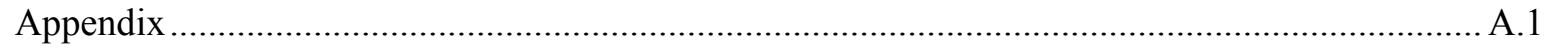

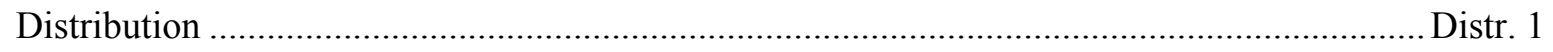




\section{Figures}

Figure S.1. Impact of the Weatherization and Intergovernmental Program on the U.S. Economy ..........viii

Figure S.2. Impact of the Building Technologies Program on the U.S. Economy .................................. xi

Figure S.3. Impact of 37 EERE Buildings-Related Projects on the U.S. Economy...............................xiv

Figure 1.1. Detailed Calculations of the ImBuild II Model ................................................................ 1.2

Figure 1.2. Impact on National Employment of a Hypothetical Once-only \$100 Million

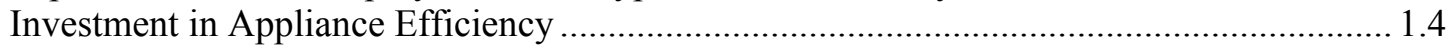




\section{Tables}

Table S.1. Impact of the Weatherization and Intergovernmental Program on the U.S. Economy.............vii

Table S.2. Impact of the Building Technologies Program on the U.S. Economy.................................... ix

Table S.3. Impact of 37 EERE Buildings-Related Projects on the U.S. Economy ..................................xiii

Table 2.1. Levels of Investment Cost and Savings from EERE Buildings-Related Projects in Fiscal Years 2004, 2005, 2010, 2020, and 2030.....

Table 2.2. Effect of Energy Savings from EERE Buildings-Related Programs on Potential National Employment

Table 2.3. Effect of Energy Savings from EERE Buildings-Related Programs on Potential National Earned Income 2.16

Table 2.4. Effect of the Full Investment Scenario on Potential National Employment 2.20

Table 2.5. Effect of the Full Investment Scenario on Potential National Earned Income 2.23

Table A.1. EERE Buildings-Related Project Investment Costs and Energy Savings, by Year (Million \$2002)

Table A.2. Allocation of EERE Buildings-Related Project Investment Costs by Sector 



\subsection{Methods}

\subsection{Introduction}

A primary goal of the Department of Energy (DOE) Office of Energy Efficiency and Renewable Energy (EERE) is to save energy. However, EERE projects also have economic impacts as energy investments, and the resultant energy savings, play out in the national economy. As part of measuring the impact of government projects on improving the energy efficiency of the nation's building stock, EERE is interested in assessing the economic impacts of these projects, specifically the impact on national employment and earned income. As a consequence, EERE funded Pacific Northwest National Laboratory (PNNL) to develop a simple-to-use method that could be used in-house to estimate economic impacts of individual projects.

Three fundamental methods are available to estimate employment and earned income impacts for selected energy efficiency improvements in the U.S. economy: multipliers, input-output models, and macroeconomic simulation models. PNNL staff reviewed the EERE programmatic needs and available methods and, based on this assessment and on realistic resource constraints, designed and developed a special-purpose version of the IMpact Analysis for PLANning (IMPLAN) national input-output model (Minnesota IMPLAN Group, Inc. 1997) specifically to estimate the employment and income effects of building energy technologies. IMPLAN was developed originally by the U.S. Forest Service in cooperation with the Federal Emergency Management Agency and the Bureau of Land Management to assist the Forest Service in land and resource management planning. Since 1979, it has been used by a wide variety of government and private agencies to assess economic impacts. The special-purpose version of the IMPLAN model developed by PNNL was called ImBuild. The version used in this study is called ImBuild II. Extensive documentation and a user's guide are provided in Scott et al. (2002), which discusses the methods, structure of the ImBuild II model, its testing and performance. For a detailed discussion of the methodology used in this study, refer to that report. Compared with simple economic multiplier approaches, such as the published multipliers from the Department of Commerce Regional Input-Output Modeling System (RIMS II) (Bureau of Economic Analysis 1992), ImBuild II allows for more complete and automated analysis of the economic impacts of energy efficiency investments in buildings. ImBuild II is also easier to use than existing macroeconomic simulation models.

In comparison with simple multipliers, ImBuild II allows for more complete and automated analysis of essential features of energy efficiency investments in buildings. ImBuild II is also easier to use than extant macroeconomic simulation models. It does not include the ability to model certain dynamic features of markets for labor and other factors of production featured in these more complex models, but for most purposes these excluded features are not critical. Such impacts can be handled well by an inputoutput model and the analysis should be credible, as long as the assumption can be made that relative prices in the economy would not be substantially affected by energy efficiency investments. The expected scale of these investments is small enough in most cases that neither labor markets nor production cost relationships will seriously affect national prices as the investments are made. The exact timing of impacts on gross product, employment, and national earned income from energy efficiency 
investments is not well enough understood that much special insight can be gained from the additional dynamic sophistication of a macroeconomic simulation model. Thus, ImBuild II is a cost-effective compromise.

\subsection{Calculation of Impact Using ImBuild}

As cost-effective, energy-efficient technologies penetrate the marketplace, EERE buildings-related projects will affect national employment and earned income. To analyze these effects, the ImBuild II model requires certain information on the projects: the size of the incremental investment in the technology over time compared with the conventional technology it replaces, corresponding energy savings by fuel in physical and monetary terms (which may include additional use of some fuels when one type of fuel replaces another), and non-energy operations savings (if any) in comparison with the current technology (Figure 1.1).

ImBuild II calculates changes in the use of energy, labor, and materials due to incremental investments and economic savings associated with EERE-supported technologies and practices, as shown in Figure 1.1. As the figure illustrates, new investments in these technologies affect the level of employment and earned income in the economy by multiple pathways. First, the procurement of equipment and installation services creates jobs and income in some industries, while diverting funds that otherwise would have been spent for other goods and services by businesses and consumers. At the same time, the investment in energy-efficient technologies or practices may make other investments in energy supply technologies (for example, power plants) unnecessary, directly and indirectly affecting jobs and income.

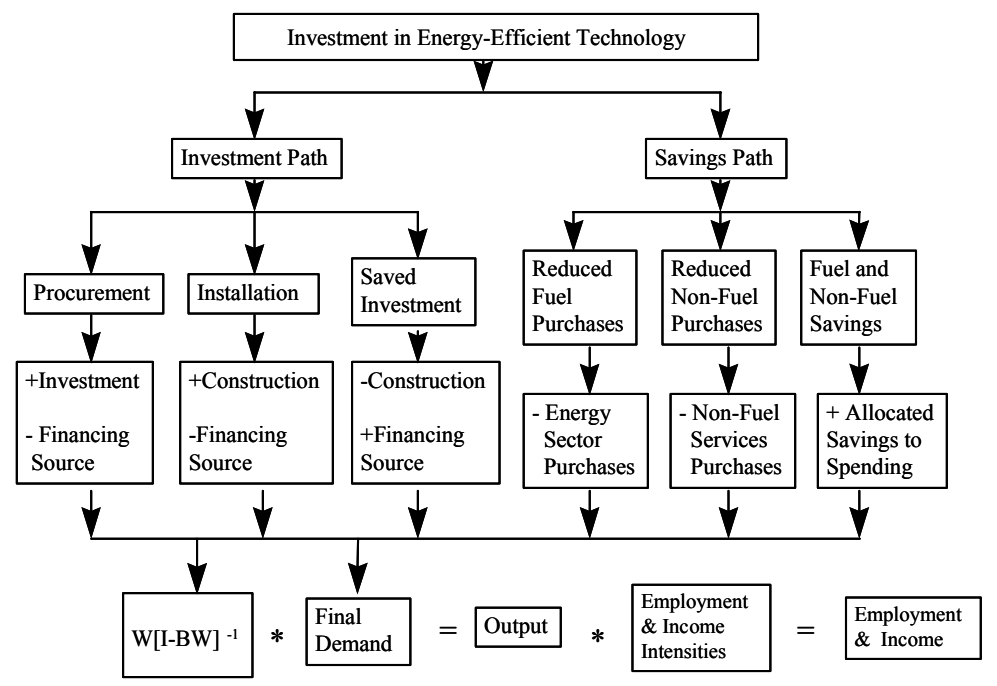

Figure 1.1. Detailed Calculations of the ImBuild II Model 
The issue is discussed in more detail in Scott et al. (2002). ${ }^{(b)}$ For this report, we assumed that financing for the energy-efficient investments is drawn proportionately from the rest of the U.S. economy. ${ }^{(c)}$ Figure 1.1 also shows that an investment in energy-efficient technology reduces the amount of energy needed. Reducing energy consumption reduces energy purchases (which in turn reduces employment and income in the energy-supplying sectors) and produces dollar savings that can be spent on any good or service, including energy (which creates employment and income). In addition, some energy efficiency investments may save the purchaser other costs such as maintenance services, and these savings also have impacts.

All of these pathways in Figure 1.1 either affect the interindustry intermediate procurement (the matrix $\mathrm{W}[\mathrm{I}-\mathrm{BW}]^{-1}$ in Figure 1.1) or the final demand (the set of goods and services in the economy purchased for final consumption or new investment, as distinguished from those purchased merely as intermediate inputs to current production). In residential applications, the necessary model calculations are relatively straightforward, because residential savings are assumed to be entirely recycled into personal consumption and investment (that is, final demand). For commercial building applications, the process is more complicated because the interindustry relationships between specific sectors are affected, not just final demand. For savings in the commercial sector, the interindustry portion of the input-output table is automatically recomputed; then the model is run with the recomputed table. Because the energy and maintenance intensity of the commercial sector changes, the coefficients of the input-output structure are automatically recalculated at each time step. The financial impacts of energy and non-energy cost savings (for example, savings in building maintenance) are computed by the model. These savings are treated like "free" income, available to be saved or invested by the sector collecting the income.

A brief hypothetical example from Scott et al. (2002) illustrates the concepts and functioning of the ImBuild II model. It is assumed that consumers spend a premium of $\$ 100$ million on more-efficient residential heating and air-conditioning equipment in the year 2000, which each year thereafter saves them $\$ 15$ million in electricity, \$30 million in natural gas, and \$5 million in building maintenance expenditures, for annual savings of $\$ 50$ million. This $\$ 50$ million annual savings yields a simple payback period of 2 years. The first two cases in Figure 1.2 show the employment effects of the $\$ 50$ million savings alone. In the first case, the savings are confined to the residential sector. The second case shows how the impacts would change if these energy savings had instead been experienced in the commercial sector, where the savings are initially experienced as an increase in the profitability of those businesses saving the energy.

(b) For this report, we estimated electric power plant construction savings at about $\$ 590 / \mathrm{kW}$ of delivered electric energy, based on data in EIA (2002) and the equivalent value for natural gas, about $\$ 1.20 /$ cubic foot/day capacity, based on EIA (1996) and EIA (1999). These values have not changes significantly in recent years.

(c) It is assumed that personal (household) consumption represents $70 \%$ of spending; gross private fixed investment, $10 \%$; federal defense spending $2 \%$; federal non-defense spending, $6 \%$; and state and local government spending, about $12 \%$. These percentages are close to the actual distribution of final demand among these sectors in the U.S. economy. 


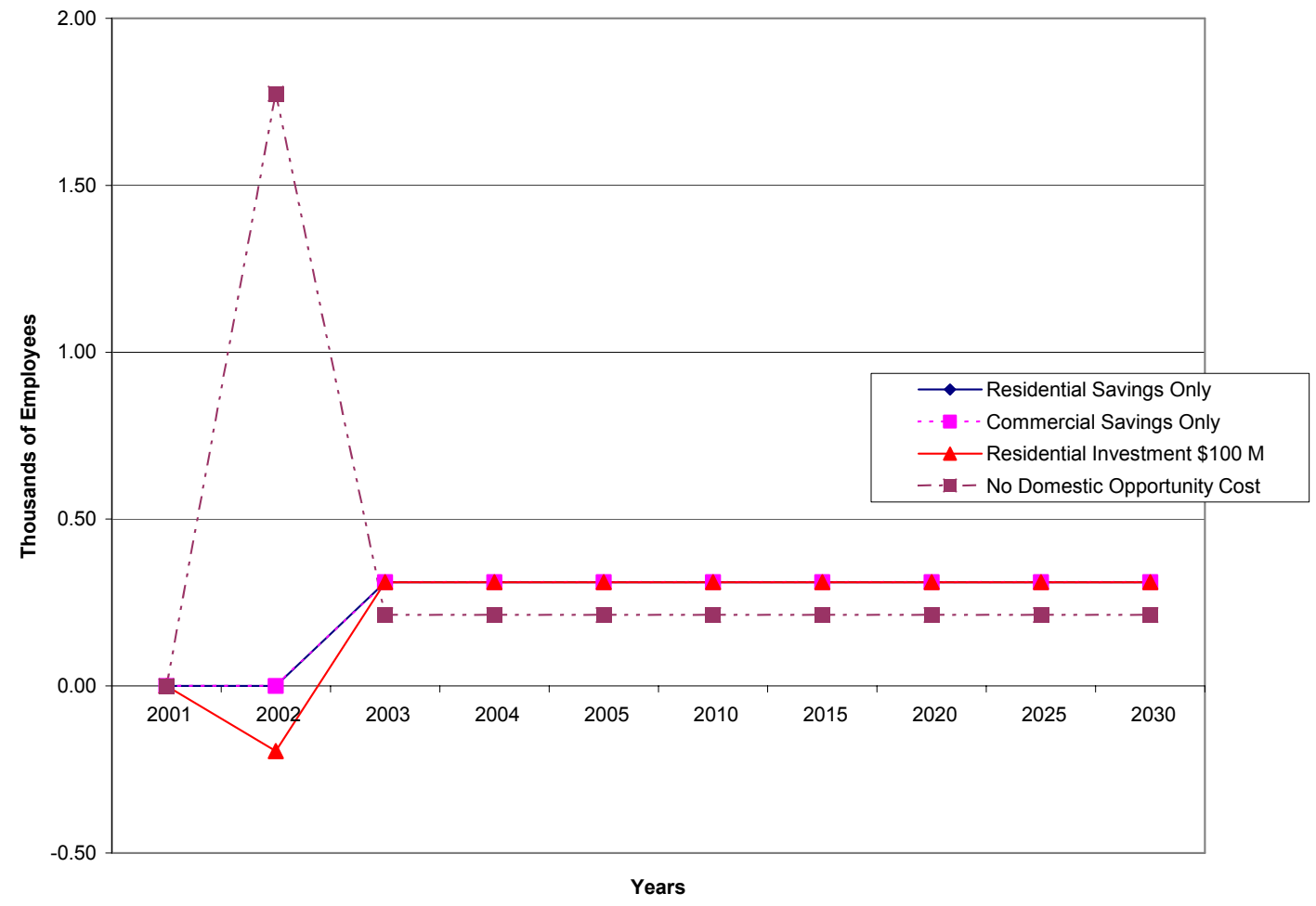

Figure 1.2. Impact on National Employment of a Hypothetical Once-only $\$ 100$ Million Investment in Appliance Efficiency

These profits are assumed to be recycled in the economy as spending by workers, spending by the firms themselves, and by governments experiencing increases in tax collections. In the first case, the energy savings in the residential sector of $\$ 50$ million have a net impact on the U.S. economy of about 310 jobs, or about 0.6 additional jobs per $\$ 100$ thousand dollars of direct energy savings. The impact is virtually identical if the energy savings occur in the commercial sector, because the employment intensity of the spending mix of businesses, their workers, and government associated with commercial savings is only slightly different from the spending intensity of the household sector alone, which is associated with residential saving. Next, Figure 1.2 adds a third and fourth case to show the employment impacts of the $\$ 100$ million investment itself. The third case shows the impact of the investment premium. In this case, even though investment in the technology itself generates employment, the short run net employment impact is negative (minus 200 jobs) because the opportunity cost of the investment premium is the dollar amount the investment would have produced elsewhere in the U.S. economy, which on average is more labor-intensive than the manufacturing sector that makes the new technology. ${ }^{(\mathrm{d})}$ Typically, efficiency projects are considered relatively labor-intensive, but this is not always the case. Heating and air conditioning manufacture, for example, is quite capital-intensive. The strength and direction of the

(d) Strictly speaking, the labor intensity that counts is the employment, direct and indirect, that is created by each dollar of spending. Thus, it is theoretically possible for a capital-intensive industry to buy lots of laborintensive inputs from other industries and the total effect to be labor intensive as a result. 
investment effect depends on the size of the investment premium and its combined domestic U.S. direct and indirect labor intensity, relative to that of other domestic spending (the opportunity cost of the investment). For the employment impact of the investment to be positive, the sectors supplying the new technology must on average create more domestic jobs per dollar of spending than does other domestic spending. An extreme form of this positive investment effect would occur, if the investment were financed internationally (that is, no domestic opportunity cost is included). This is the fourth case in Figure 1.2, which shows a short-run jobs impact of more than 1770 and a long-run jobs impact of 210. The fourth case also corresponds to many regional analyses that have been made of energy conservation impacts, where the investment funds are assumed to come from somewhere else and have no opportunity cost in the region.

The energy and non-energy savings from installation of efficient technology do not affect employment in the national economy until reinvested or spent. For purposes of the analysis conducted for this report, we assume that any increments to the economic value-added in each sector as a result of the investment (that is, the energy and non-energy savings) are allocated to compensation of labor, capital, and business taxes in the same proportions as all other value-added ${ }^{(e)}$ in that sector. The income of each sector then is assumed to be spent on investment and consumption of goods and services (final demand) in the same proportions as existing compensation of labor, capital, and government. That is, if a given sector captures $1 \%$ of all personal consumption expenditures in the economy and a $0.7 \%$ share of all business fixed investment, it will receive these same percentage shares of the efficiency-related increase in spending. Similarly, if labor compensation represents $70 \%$ of the baseline total value added in an industry, it will receive $70 \%$ of any energy savings in that industry. Finally, labor compensation, business profits and taxes are allocated to consumption, investment, and government spending, according to current proportions.

ImBuild accumulates the energy and non-energy savings in the residential buildings sector and the changes in economic value-added associated with energy and non-energy savings within the commercial buildings sector. The model then calculates spending impacts associated with these savings by proportionately increasing final demand across all sectors as noted previously, while at the same time reducing final demand in the sectors supplying the resources that are saved. This step accounts for the spending associated with the monetary savings and improvements in technological efficiency and for the associated shift from energy to non-energy spending. It also accounts for changes in the patterns of activity in the economy due to technological change caused by the EERE projects (that is, less electricity is used per dollar of output in retailing because of more efficient lighting). ${ }^{(\mathrm{f})}$

(e) Economic value-added is the value of output of the sector, less the cost of purchased materials and services. The sum of value-added in all sectors is Gross Domestic Product (GDP).

(f) ImBuild does not account for all of the long-term run impacts of the technological change. The change in energy-using capital in the commercial sector would alter the marginal value of all of the factors of production (including both labor and capital) and would induce a rearrangement of capital and labor that would ultimately result in an increase in output and in final demand. We show the multiplier effect created by spending of the energy and non-energy savings, but not the productivity effect of increased capital stock that would be created by the investment portion of the spending. Most economic models, including many dynamic simulation models, do not completely reflect the effect of capital accumulation and growth in capacity on final output and employment. 
ImBuild collects the estimates of the initial investments, energy and non-energy savings, and economic activity associated with spending of the savings (increases in final demand in personal consumption, business investment, and government spending), and provides overall estimates of the increase in national output for each economic sector using the adjusted input-output matrix. Finally, the model applies estimates of employment and earned income per dollar of economic output for each sector and calculates impacts on national employment and earned income. 


\subsection{Analysis}

\subsection{EERE Buildings-Related Projects}

This analysis encompasses the EERE buildings-related projects that were evaluated for FY 2004 in response to the Government Performance and Results Act (GPRA). Table 2.1 shows the level of incremental residential and commercial investments and net energy savings in the selected years 2004, 2005, 2010, 2020, and 2030 for the buildings-related projects that were evaluated. Each project is designated with a numerical project code or "Projcode" to ensure ease in numerical modeling and for tracing a given project as it undergoes periodic name changes. It is important to note that the values in Table 2.1 represent levels of current investment and energy and non-energy savings in the year shown, because it is current investment and current energy and non-energy savings that determine the impact on employment and earned income. Reported in this way, the values in Table 2.1 cannot be used to determine a rate of return on any particular investment because an investment in a given year provides a stream of savings over several years, and the energy savings experienced in any particular year are a function of the cumulative previous investment in energy efficiency. The investment and energy savings levels in a given year affect the level of gross domestic product (GDP) in that year, in turn affecting the level of national employment and earned income. Although the projects differ from each other in size and timing, for the most part the annual investment exceeds the annual savings early in the period, and savings tend to dominate later on. In a few cases, the early investments are expected to be so durable and to fall so much in cost that the later years show investment savings vis-à-vis conventional technology.

The differences in investment reflect differences identified by the analysis as the size of the potential market opportunity or market niche for each project, differences in the expected rate of market penetration into each niche, and differences concerning the incremental cost of the new technologies and practices penetrating the market, compared to the more conventional technologies or practices that they replace. By 2030, about eight percent of the total value of energy savings occurs in projects like Commercial Building R\&D or Analysis Tools and Design that are not projected to require any incremental investment over and above standard practice. Current savings do not necessarily correlate well with current investments. Some technologies and practices are expected to be extremely costeffective and require relatively little incremental investment, while others require relatively more incremental investment or may be less cost-effective. Savings are also sensitive to timing. For example, some projects like Energy Star Water Heaters are expected to be still in the midst of their intensive incremental investment phase in the year 2030, while others like Rebuild America are largely completed and are enjoying pure savings by that date. For Weatherization and Intergovernmental Program details and Building Technologies Program project details, refer to the GPRA documentation report (Anderson et al. 2003).

Many of the EERE buildings-related projects have increasing market penetration and investment levels through the year 2030. Thus, the energy savings levels for many of the projects are expected to increase far beyond 2030. By the end of the period shown in Table 2.1, total annual savings have substantially exceeded total annual investments, and are continuing to accelerate. Investments as a group have begun to flatten out by 2015. Some of the incremental adoption of the technologies and the energy investments 
due to the projects accelerates an adoption process that would have occurred later, anyway. Incremental investments due to these EERE projects are overtaken by "normal" investments in the space of three to ten years, depending on the project. In other cases, it can be argued that the technology or practice never would have been developed without the EERE project; therefore, the investment and savings would not have been overtaken in the marketplace. For details, see Anderson et al. (2003).

Table 2.1. Levels of Investment Cost and Savings from EERE Buildings-Related Projects in Fiscal Years 2004, 2005, 2010, 2020, and 2030

\begin{tabular}{|c|c|c|c|c|c|}
\hline \multirow[b]{2}{*}{ Project and Category } & \multicolumn{5}{|c|}{ Investment Costs and Savings (Million 2002\$) } \\
\hline & 2004 & 2005 & 2010 & 2020 & 2030 \\
\hline \multicolumn{6}{|l|}{ 1. Weatherization Assistance } \\
\hline \multicolumn{6}{|l|}{901 Weatherization Assistance } \\
\hline Investment & $\$ 535.7$ & $\$ 531.6$ & $\$ 569.5$ & $\$ 577.6$ & $\$ 577.6$ \\
\hline Savings & $\$ 68.2$ & $\$ 133.1$ & $\$ 469.1$ & $\$ 1,045.5$ & $\$ 1,076.3$ \\
\hline \multicolumn{6}{|l|}{ 2. State Energy Program } \\
\hline \multicolumn{6}{|l|}{903 State Energy Program } \\
\hline Investment & $\$ 164.0$ & $\$ 164.0$ & $\$ 164.0$ & $\$ 164.0$ & $\$ 164.0$ \\
\hline Savings & $\$ 54.3$ & $\$ 54.3$ & $\$ 180.0$ & $\$ 401.8$ & $\$ 418.5$ \\
\hline \multicolumn{6}{|l|}{ 3. Gateway Deployment } \\
\hline \multicolumn{6}{|l|}{1332 Rebuild America } \\
\hline Investment & $\$ 209.9$ & $\$ 209.9$ & $\$ 514.1$ & $\$ 41.2$ & $\$ 38.4$ \\
\hline Savings & $\$ 22.0$ & $\$ 22.0$ & $\$ 129.3$ & $\$ 176.2$ & $\$ 182.3$ \\
\hline \multicolumn{6}{|l|}{$\begin{array}{l}1336 \text { Energy Efficiency Information } \\
\text { Outreach }\end{array}$} \\
\hline Investment & $\$ 173.3$ & $\$ 173.3$ & $\$ 168.2$ & $\$ 175.7$ & $\$ 176.7$ \\
\hline Savings & $\$ 199.5$ & $\$ 199.5$ & $\$ 282.2$ & $\$ 291.0$ & $\$ 299.9$ \\
\hline \multicolumn{6}{|l|}{$\begin{array}{l}1338 \text { Building Codes Training and } \\
\text { Assistance }\end{array}$} \\
\hline Investment & $\$ 210.7$ & $\$ 210.7$ & $\$ 806.2$ & $\$ 1,016.2$ & $\$ 930.6$ \\
\hline Savings & $\$ 82.8$ & $\$ 82.8$ & $\$ 580.8$ & $\$ 2,933.5$ & $\$ 4,908.2$ \\
\hline
\end{tabular}




\begin{tabular}{|c|c|c|c|c|c|}
\hline \multirow[b]{2}{*}{ Project and Category } & \multicolumn{5}{|c|}{ Investment Costs and Savings (Million 2002\$) } \\
\hline & 2004 & 2005 & 2010 & 2020 & 2030 \\
\hline \multicolumn{6}{|c|}{422 Energy Star Details in 4221-4228 } \\
\hline \multicolumn{6}{|l|}{4221 Energy Star: Clothes Washers } \\
\hline Investment & $\$ 342.0$ & $\$ 342.0$ & $\$ 356.9$ & $\$ 450.7$ & $\$ 496.8$ \\
\hline Savings & $\$ 141.5$ & $\$ 141.5$ & $\$ 325.0$ & $\$ 591.4$ & $\$ 883.2$ \\
\hline \multicolumn{6}{|l|}{4223 Energy Star: Refrigerators } \\
\hline Investment & $\$ 193.9$ & $\$ 193.9$ & $\$ 386.4$ & $\$ 432.0$ & $\$ 465.5$ \\
\hline Savings & $\$ 7.7$ & $\$ 7.7$ & $\$ 54.9$ & $\$ 142.4$ & $\$ 238.6$ \\
\hline \multicolumn{6}{|l|}{4226 Energy Star: Electric Water Heaters } \\
\hline Investment & $\$ 17.5$ & $\$ 17.5$ & $\$ 164.1$ & $\$ 153.2$ & $\$ 157.3$ \\
\hline Savings & $\$ 4.0$ & $\$ 4.0$ & $\$ 122.0$ & $\$ 606.1$ & $\$ 1,276.5$ \\
\hline \multicolumn{6}{|l|}{4225 Energy Star: Gas Water Heaters } \\
\hline Investment & $\$ 10.6$ & $\$ 10.6$ & $\$ 50.4$ & $\$ 113.3$ & $\$ 131.2$ \\
\hline Savings & $\$ 0.5$ & $\$ 0.5$ & $\$ 11.0$ & $\$ 78.1$ & $\$ 185.1$ \\
\hline \multicolumn{6}{|l|}{4224 Energy Star: Room Air Conditioners } \\
\hline Investment & $\$ 375.6$ & $\$ 375.6$ & $\$ 363.9$ & $\$ 448.2$ & $\$ 485.2$ \\
\hline Savings & $\$ 4.5$ & $\$ 4.5$ & $\$ 14.0$ & $\$ 34.4$ & $\$ 58.9$ \\
\hline \multicolumn{6}{|l|}{4228 Energy Star: CFLs } \\
\hline Investment & $\$ 29.2$ & $\$ 29.2$ & $\$ 26.3$ & $-\$ 683.4$ & $-\$ 2,502.6$ \\
\hline Savings & $\$ 80.2$ & $\$ 80.2$ & $\$ 784.1$ & $\$ 4,929.5$ & $\$ 6,266.9$ \\
\hline \multicolumn{6}{|l|}{4222 Energy Star: Dishwashers } \\
\hline Investment & $\$ 113.2$ & $\$ 113.2$ & $\$ 118.6$ & $\$ 137.4$ & $\$ 151.7$ \\
\hline Savings & $\$ 3.0$ & $\$ 3.0$ & $\$ 13.2$ & $\$ 38.4$ & $\$ 72.3$ \\
\hline \multicolumn{6}{|l|}{ 4. Residential Buildings Integration } \\
\hline \multicolumn{6}{|l|}{$\begin{array}{l}115 \text { Research \& Development (Building } \\
\text { America) }\end{array}$} \\
\hline Investment & $\$ 48.2$ & $\$ 48.2$ & $\$ 128.0$ & $\$ 26.7$ & $\$ 26.7$ \\
\hline
\end{tabular}




\begin{tabular}{|c|c|c|c|c|c|}
\hline \multirow[b]{2}{*}{ Project and Category } & \multicolumn{5}{|c|}{ Investment Costs and Savings (Million 2002\$) } \\
\hline & 2004 & 2005 & 2010 & 2020 & 2030 \\
\hline Savings & $\$ 7.0$ & $\$ 7.0$ & $\$ 76.3$ & $\$ 189.6$ & $\$ 231.6$ \\
\hline \multicolumn{6}{|l|}{506 Residential Building Energy Codes } \\
\hline Investment & $\$ 0.0$ & $\$ 0.0$ & $\$ 18.2$ & $\$ 138.1$ & $\$ 158.0$ \\
\hline Savings & $\$ 0.0$ & $\$ 0.0$ & $\$ 6.7$ & $\$ 227.3$ & $\$ 560.5$ \\
\hline \multicolumn{6}{|l|}{116 Zero Energy Buildings } \\
\hline Investment & $\$ 31.5$ & $\$ 46.8$ & $\$ 158.0$ & $\$ 414.1$ & $\$ 746.3$ \\
\hline Savings & $\$ 2.3$ & $\$ 6.0$ & $\$ 72.9$ & $\$ 692.2$ & $\$ 2,084.9$ \\
\hline \multicolumn{6}{|l|}{ 5. Commercial Buildings Integration } \\
\hline \multicolumn{6}{|l|}{124 Research \& Development } \\
\hline Investment & $\$ 0.0$ & $\$ 0.0$ & $\$ 0.0$ & $\$ 0.0$ & $\$ 0.0$ \\
\hline Savings & $\$ 3.6$ & $\$ 3.6$ & $\$ 82.1$ & $\$ 1,187.8$ & $\$ 1,879.2$ \\
\hline \multicolumn{6}{|l|}{507 Commercial Building Energy Codes } \\
\hline Investment & $\$ 0.0$ & $\$ 0.0$ & $\$ 22.3$ & $\$ 305.5$ & $\$ 435.9$ \\
\hline Savings & $\$ 0.0$ & $\$ 0.0$ & $\$ 6.6$ & $\$ 405.5$ & $\$ 1,209.6$ \\
\hline \multicolumn{6}{|l|}{ 6. Emerging Technologies } \\
\hline \multicolumn{6}{|c|}{430 Lighting R\&D Details in $4304-440$} \\
\hline \multicolumn{6}{|l|}{4304 Lighting R\&D: Controls } \\
\hline Investment & $\$ 35.3$ & $\$ 28.8$ & $\$ 93.7$ & $\$ 58.2$ & $\$ 66.2$ \\
\hline Savings & $\$ 9.9$ & $\$ 17.9$ & $\$ 111.9$ & $\$ 355.6$ & $\$ 550.7$ \\
\hline \multicolumn{6}{|l|}{440 Next Generation Lighting Initiative } \\
\hline Investment & $\$ 0.0$ & $\$ 0.0$ & $\$ 0.0$ & $\$ 31.6$ & $\$ 103.8$ \\
\hline Savings & $\$ 0.0$ & $\$ 0.0$ & $\$ 0.0$ & $\$ 398.9$ & $\$ 1,484.4$ \\
\hline \multicolumn{6}{|c|}{380 Space Conditioning \& Refrigeration R\&D Details in 3801-3804 } \\
\hline \multicolumn{6}{|l|}{$\begin{array}{l}3801 \text { Refrigeration R\&D: Res. HVAC } \\
\text { Dist. System }\end{array}$} \\
\hline Investment & $\$ 104.9$ & $\$ 152.1$ & $\$ 540.5$ & $\$ 248.0$ & $\$ 313.9$ \\
\hline
\end{tabular}




\begin{tabular}{|c|c|c|c|c|c|}
\hline \multirow[b]{2}{*}{ Project and Category } & \multicolumn{5}{|c|}{ Investment Costs and Savings (Million 2002\$) } \\
\hline & 2004 & 2005 & 2010 & 2020 & 2030 \\
\hline Savings & $\$ 30.3$ & $\$ 56.3$ & $\$ 300.2$ & $\$ 1,007.7$ & $\$ 358.5$ \\
\hline \multicolumn{6}{|l|}{$\begin{array}{l}3802 \text { Refrigeration R\&D: Adv. Elec. } \\
\text { HPWH }\end{array}$} \\
\hline Investment & $\$ 1.6$ & $\$ 3.8$ & $\$ 26.8$ & $\$ 179.8$ & $\$ 27.3$ \\
\hline Savings & $\$ 0.8$ & $\$ 2.7$ & $\$ 33.4$ & $\$ 586.1$ & $\$ 478.3$ \\
\hline \multicolumn{6}{|c|}{$\begin{array}{l}3803 \text { Refrigeration R\&D: Commercial } \\
\text { Refrigeration }\end{array}$} \\
\hline Investment & $\$ 10.4$ & $\$ 15.1$ & $\$ 57.2$ & $-\$ 22.1$ & $-\$ 33.3$ \\
\hline Savings & $\$ 6.6$ & $\$ 12.3$ & $\$ 68.9$ & $\$ 302.8$ & $\$ 28.3$ \\
\hline \multicolumn{6}{|c|}{$\begin{array}{l}3804 \text { Refrigeration R\&D: Refrigerant } \\
\text { Meter }\end{array}$} \\
\hline Investment & $\$ 4.9$ & $\$ 12.0$ & $\$ 84.8$ & $\$ 497.8$ & $\$ 56.3$ \\
\hline Savings & $\$ 2.1$ & $\$ 7.2$ & $\$ 88.5$ & $\$ 1,389.1$ & $\$ 1,017.7$ \\
\hline \multicolumn{6}{|c|}{381 Appliances \& Emerging Technologies R\&D Details in 3811-3817 } \\
\hline \multicolumn{6}{|c|}{$\begin{array}{l}3811 \text { Appliances \& Emerging Tech R\&D: } \\
\text { HPWH }\end{array}$} \\
\hline Investment & $\$ 22.8$ & $\$ 35.0$ & $\$ 137.5$ & $\$ 93.7$ & $\$ 99.6$ \\
\hline Savings & $\$ 27.2$ & $\$ 44.8$ & $\$ 232.1$ & $\$ 713.5$ & $\$ 1,048.1$ \\
\hline \multicolumn{6}{|c|}{$\begin{array}{l}3813 \text { Appliances \& Emerging Tech R\&D: } \\
\text { Roof Top AC }\end{array}$} \\
\hline Investment & $\$ 13.9$ & $\$ 11.6$ & $\$ 8.8$ & $\$ 8.6$ & $\$ 7.8$ \\
\hline Savings & $\$ 4.7$ & $\$ 8.5$ & $\$ 17.7$ & $\$ 30.2$ & $\$ 41.8$ \\
\hline \multicolumn{6}{|l|}{$\begin{array}{l}3815 \text { Emerging Tech R\&D: Gas } \\
\text { Condensing WH }\end{array}$} \\
\hline Investment & $\$ 2.9$ & $\$ 4.8$ & $\$ 22.6$ & $\$ 0.0$ & $\$ 3.3$ \\
\hline Savings & $\$ 1.7$ & $\$ 4.4$ & $\$ 52.4$ & $\$ 189.3$ & $\$ 263.8$ \\
\hline \multicolumn{6}{|c|}{$\begin{array}{l}3816 \text { Appliances \& Emerging Tech R\&D: } \\
\text { Recessed Can Lights }\end{array}$} \\
\hline Investment & $\$ 7.5$ & $\$ 17.7$ & $\$ 83.2$ & $-\$ 43.0$ & $-\$ 49.1$ \\
\hline
\end{tabular}




\begin{tabular}{|c|c|c|c|c|c|}
\hline \multirow[b]{2}{*}{ Project and Category } & \multicolumn{5}{|c|}{ Investment Costs and Savings (Million 2002\$) } \\
\hline & 2004 & 2005 & 2010 & 2020 & 2030 \\
\hline Savings & $\$ 2.3$ & $\$ 7.1$ & $\$ 91.8$ & $\$ 370.2$ & $\$ 375.9$ \\
\hline \multicolumn{6}{|c|}{$\begin{array}{l}3817 \text { Appliances \& Emerging Tech R\&D: } \\
\text { R-Lamp }\end{array}$} \\
\hline Investment & $\$ 12.9$ & $\$ 11.1$ & $-\$ 26.0$ & $-\$ 78.9$ & $-\$ 81.7$ \\
\hline Savings & $\$ 53.1$ & $\$ 102.5$ & $\$ 316.4$ & $\$ 0.0$ & $\$ 0.0$ \\
\hline \multicolumn{6}{|c|}{2111 Building Envelope R\&D: Window Technologies Details in 2114-2115 } \\
\hline \multicolumn{6}{|l|}{$\begin{array}{l}2114 \text { Window Technologies: } \\
\text { Electrochromic Windows }\end{array}$} \\
\hline Investment & $\$ 159.6$ & $\$ 193.3$ & $\$ 264.7$ & $\$ 349.7$ & $\$ 434.3$ \\
\hline Savings & $\$ 63.4$ & $\$ 85.1$ & $\$ 184.9$ & $\$ 511.2$ & $\$ 950.5$ \\
\hline \multicolumn{6}{|l|}{$\begin{array}{l}2115 \text { Window Technologies: } \\
\text { Superwindows }\end{array}$} \\
\hline Investment & $\$ 567.6$ & $\$ 691.0$ & $\$ 1,593.8$ & $\$ 1,870.7$ & $\$ 2,919.3$ \\
\hline Savings & $\$ 75.3$ & $\$ 114.0$ & $\$ 386.8$ & $\$ 1,701.2$ & $\$ 3,231.3$ \\
\hline \multicolumn{6}{|c|}{2112 Building Envelope R\&D: Thermal Insulation \& Building Materials Details in 2116-2118 } \\
\hline \multicolumn{6}{|c|}{2116 Thermal Insulation: Quick Fill Walls } \\
\hline Investment & $\$ 1.5$ & $\$ 0.4$ & $\$ 3.5$ & $\$ 13.8$ & $\$ 16.0$ \\
\hline Savings & $\$ 0.6$ & $\$ 0.8$ & $\$ 4.3$ & $\$ 41.5$ & $\$ 97.2$ \\
\hline \multicolumn{6}{|l|}{$\begin{array}{l}2117 \text { Thermal Insulation: R30 } \\
\text { Insulation/30 Year Life Roofs }\end{array}$} \\
\hline Investment & $\$ 0.0$ & $\$ 0.0$ & $\$ 0.0$ & $\$ 0.0$ & $\$ 0.0$ \\
\hline Savings & $\$ 0.0$ & $\$ 0.0$ & $\$ 2.0$ & $\$ 97.1$ & $\$ 247.9$ \\
\hline \multicolumn{6}{|c|}{$\begin{array}{l}2118 \text { Thermal Insulation: Moisture/Wet } \\
\text { Insulation }\end{array}$} \\
\hline Investment & $\$ 24.3$ & $\$ 34.9$ & $\$ 89.2$ & $\$ 187.9$ & $\$ 225.7$ \\
\hline Savings & $\$ 6.2$ & $\$ 12.2$ & $\$ 62.4$ & $\$ 339.6$ & $\$ 736.9$ \\
\hline \multicolumn{6}{|l|}{145 Analysis Tools and Design } \\
\hline Investment & $\$ 0.0$ & $\$ 0.0$ & $\$ 0.0$ & $\$ 0.0$ & $\$ 0.0$ \\
\hline
\end{tabular}




\begin{tabular}{|c|c|c|c|c|c|}
\hline \multirow[b]{2}{*}{ Project and Category } & \multicolumn{5}{|c|}{ Investment Costs and Savings (Million 2002\$) } \\
\hline & 2004 & 2005 & 2010 & 2020 & 2030 \\
\hline Savings & $\$ 2.4$ & $\$ 4.6$ & $\$ 27.6$ & $\$ 344.9$ & $\$ 824.3$ \\
\hline \multicolumn{6}{|c|}{ 7. Equipment Standards and Analysis } \\
\hline \multicolumn{6}{|c|}{603 Equipment Standards and Analysis Details in 6039-6044 } \\
\hline \multicolumn{6}{|c|}{6043 Standards: Res. Gas Furnaces/Boilers } \\
\hline Investment & $\$ 0.0$ & $\$ 0.0$ & $\$ 25.9$ & $\$ 5.7$ & $-\$ 0.4$ \\
\hline Savings & $\$ 0.0$ & $\$ 0.0$ & $\$ 35.0$ & $\$ 230.1$ & $\$ 464.6$ \\
\hline \multicolumn{6}{|l|}{6044 Standards: EPAct Standards } \\
\hline Investment & $\$ 201.9$ & $\$ 209.3$ & $\$ 1,055.7$ & $\$ 1,451.2$ & $\$ 618.2$ \\
\hline Savings & $\$ 24.6$ & $\$ 50.0$ & $\$ 454.5$ & $\$ 2,128.5$ & $\$ 2,842.8$ \\
\hline \multicolumn{6}{|c|}{6039 Standards: Distribution Transformers } \\
\hline Investment & $\$ 0.0$ & $\$ 0.0$ & $\$ 595.0$ & $\$ 798.3$ & $\$ 235.8$ \\
\hline Savings & $\$ 0.0$ & $\$ 0.0$ & $\$ 202.1$ & $\$ 992.2$ & $\$ 1,233.0$ \\
\hline \multicolumn{6}{|c|}{ Weatherization and Intergovernmental Program (DU 1-3) } \\
\hline Investment & $\$ 1,966.7$ & $\$ 2,371.7$ & $\$ 3,688.7$ & $\$ 3,025.9$ & $\$ 1,272.3$ \\
\hline Savings & $\$ 392.0$ & $\$ 733.2$ & $\$ 2,965.7$ & $\$ 11,268.2$ & $\$ 15,866.8$ \\
\hline \multicolumn{6}{|c|}{ Building Technologies Program (DU 4-7) } \\
\hline Investment & $\$ 846.4$ & $\$ 1,260.5$ & $\$ 4,388.6$ & $\$ 5,737.1$ & $\$ 6,094.1$ \\
\hline Savings & $\$ 159.1$ & $\$ 335.9$ & $\$ 2,917.7$ & $\$ 14,432.1$ & $\$ 22,241$. \\
\hline \multicolumn{6}{|l|}{ Total } \\
\hline Investment & $\$ 2,813.1$ & $\$ 4,216.6$ & $\$ 8,077.3$ & $\$ 8,763.1$ & $\$ 7,366.5$ \\
\hline Savings & $\$ 551.1$ & $\$ 1,703.2$ & $\$ 5,883.5$ & $\$ 25,700.3$ & $\$ 38,108.7$ \\
\hline
\end{tabular}





\subsection{Results}

The investments and energy savings attributable to the penetration of EERE buildings-related projects in the marketplace will result in substantial macroeconomic effects. The following tables summarize these effects. Table 2.2 shows the impact of the energy savings alone on potential national employment on a year-by-year and project-by project basis. The employment effects are called potential here because this estimate is really of the change in demand for workers. Actual employment effects could include changes in wage rates and also would be affected by changes in labor supply conditions. Table 2.3 shows the comparable effects on national earned income. Before accounting for investment costs, the effects of savings alone in the year 2030 are an increase of about 305,000 potential jobs and about $\$ 3.79$ billion in national earned income.

As was previously discussed, obtaining these energy savings benefits requires a substantial national investment in energy efficient technologies and practices. For the most part, this incremental national investment will be made in manufacturing sectors that are relatively capital intensive to produce new or better equipment. We assume the source of the investment capital will be the U.S. economy as a whole, which is less capital intensive on average than is manufacturing. Just as in the example in Figure 1.2, most of the energy efficiency investments will tend to reduce national employment while they are occurring, because they divert investment into capital-intensive sectors. Therefore, Table 2.4, which combines the employment effects of the required energy efficiency investments and the employment effects of the required savings, shows lower employment impacts than does Table 2.2, which includes only the effects of the energy and non-energy savings and ignores the investment effects. By 2030, Table 2.4 shows potential net employment increases of about 297,000 jobs, over $97 \%$ of level in Table 2.2 . Comparing the effects on national earned income in Tables 2.3 and 2.5 presents a similar, but slightly more mixed picture. The net effect on earned income of the required investment, combined with the effect of resulting energy and non-energy savings, is a mixed effect because many of the jobs created in the capital-intensive manufacturing sectors as a result of energy-efficiency investments are also highwage jobs. This tends to compensate to some degree for the reduction in overall employment levels associated with the diversion of national spending into capital-intensive manufacturing activity. By 2030, Table 2.5 shows a potential net positive impact on national earned income of about $\$ 4.16$ billion, about ten percent higher than the level in Table 2.3.

The individual EERE projects differ significantly from each other in scale, timing, and impact. Taking investment effects into account, more than half of the positive job and earnings impacts come from only six projects: Building Codes Training and Technical Assistance, Energy Star CFLs, Zero Energy Buildings, Next Generation Lighting Initiative, Window Technologies' Superwindows, and EPACT Standards. Together, they account for $55 \%$ of the annual savings in $2030,59 \%$ of the net savings, $57 \%$ of the net jobs, and $56 \%$ of the net earned income effects. These projects are large-scale, cost-effective projects that are expected to produce large energy savings relative to the investments required. By the year 2030, five out of the six projects each will be producing net annual economic savings to the U.S. economy of over $\$ 1.3$ billion per year (Superwindows is still undergoing significant investment, so it nets $\$ 300$ million). The combined net annual savings from the six projects is projected at about $\$ 18$ billion, even after investment costs in 2030 are subtracted. The savings alone from these projects generate an 
estimated 173,000 potential jobs (169,000 after investment effects). If the Energy Star and Lighting and Emerging Technologies projects are counted as single projects, they account for net savings impacts of $\$ 8.5$ billion and $\$ 7.6$ billion, respectively, in 2030 . They have a combined positive net impact of 169,000 jobs (164,000 after investment effects). The impacts of most of the other buildings-related projects are on a much smaller scale.

The initial effect of the required investment is a short-run reduction in jobs and income in the economy, but the net effect is small. By the year 2004, the effects of energy savings already more than compensate for the effects of investment. Many of the EERE buildings-related projects will have achieved only part of their ultimate market penetration at the end of the period. However, the overall positive net impact on positive employment (297,000 jobs) and earned income ( $\$ 4.16$ billion) in the year 2030 still is a significant boost to the economy, an effect that would continue to grow after 2030 as savings increase and investments are completed.

\subsubsection{Weatherization and Intergovernmental Program}

The Weatherization and Intergovernmental Program is a group of projects mostly focused on implementing currently available efficient technology and overcoming market barriers. It consists of three decision units: Weatherization Assistance, all State Formula Grants projects, and Gateway Deployment. The latter consists of Energy Star (which is actually a group of seven specific technology projects), Rebuild America, Information Outreach, and Training and Technical Assistance. Tables 2.2 and 2.3 show that the energy savings created by market penetration of these EERE projects have the potential of creating nearly 133,000 jobs and about $\$ 1.61$ billion in earned income (2002\$) by the year 2030. However, not all of the gains would be immediately apparent because intensive investment in new energy technology and new building practices would be required during the first 30 years of the $21^{\text {st }}$ century. These effects are incorporated in the full investment scenario shown in Tables 2.4 and 2.5. Because the Weatherization and Intergovernmental Program incremental investment tends to be concentrated high-wage industries compared with the rest of the economy, there is a slight net negative impact on employment and positive impact on earnings from this group of investments. Many of the capital investments required to achieve these savings begin early in the 30-year period. An example of a front-end loaded project is Rebuild America, for which investment is larger than savings in Table 2.1 in the first few years. However, because the employment intensities in the industries affected by investment related to this project are so similar to the U.S. economy as a whole, there is almost no net effect on employment from the investment.

To be in concert with a recent analysis of the Department of Energy's Energy Research and Development project by the National Research Council of National Academy of Sciences (NRC 2001), EERE in many cases only takes credit for the first few years of market impact. The National Research Council used a simplifying assumption that government $R \& D$ programs do no more than accelerate the technology, bringing it to market five years before the private sector would have without government intervention. For the six EERE projects to which this approach applies, the net effect is that incremental investments and savings due to the EERE projects are overtaken by "normal" investments toward the end of the period, which results in lower project-related efficiency investments and (eventually) savings than otherwise would occur (Anderson et al. 2003). The only project treated this way in the Weatherization and Intergovernmental Program is Information Outreach, and the market penetration of this technology 
continues throughout the period, as new building stock is added. Therefore, even though the market impact of a given installation is limited to three years, the overall impact of the project continues to increase. Net energy savings rise to $\$ 123$ million in 2030, slightly less than $1 \%$ of the net savings produced by all of the Weatherization and Intergovernmental Program in that year.

More generally, the more complete analysis of EERE projects performed for this report showed that the impacts on investment and energy savings result from the interaction of four factors: 1) the size of the (usually growing) market at each point in time, which results in increasing investment and savings, 2) the increasing penetration rate for the EERE technologies and practices, based on lifetime cost savings vis-àvis conventional technology and the associated payback period for the investment, which results in increasing investments and savings, 3) increases in the efficiency of a dollar of incremental investment, based in turn on the sales-volume-based rate of decline in the price of the technology and the higher durability of the EERE technology, which can considerably reduce investment even as the savings hold constant or increase, and 4) the market-transformation, crowding-out effects of one technology on market prospects of all of its potential competitors, which increases investment and savings due to the EERE project. Even in those cases where the EERE project mainly accelerates market adoption of efficient technologies, it is usually assumed that the adoption is accelerated by ten years, rather than the five years assumed by NRC. Combined with the long lead times required to introduce commercial versions of technologies to the marketplace and generally slow turnover rates of building stock, the result is that many technologies are still in the rapidly increasing market penetration phase of adoption in 2030. See Anderson et al. (2003) for assumptions concerning individual programs.

The largest net impacts come from the Energy Star projects. As shown in Table 2.4 and Table 2.5, these impacts sum to over 79,000 jobs and $\$ 882$ million in earned income in 2030 , about $60 \%$ of the net job impacts and $52 \%$ of the net income impacts produced by all of the Weatherization and Intergovernmental Program.

\subsubsection{Building Technologies Program}

The rest of EERE buildings-related projects are grouped together under the heading Building Technologies Program. As the name suggests, this is a group of projects that is focused on advancing the development of new technologies and analysis techniques for the building sector. It comprises four decision units: Residential Buildings Integration, Commercial Buildings Integration, Emerging Technologies (in lighting, refrigeration, appliances, windows, and insulation), and Equipment Standards and Analysis. Tables 2.2 and 2.3 show that the energy savings associated with these EERE projects have the potential of creating nearly 172,000 jobs and about $\$ 2.18$ billion in earned income (2002\$) by the year 2030. Not all of the gains would be immediately apparent because intensive investment in new energy technology and new building practices would be required during the first 30 years of the $21^{\text {st }}$ century. Also, because the Buildings Technologies projects investments tend to be concentrated in capitalintensive, high-wage industries, there is a slight net negative impact on employment and positive impact on earnings from this group of investments. The net impacts of the Building Technologies projects on national employment and earned income are shown in Table 2.4 and Table 2.5, respectively.

Timing of incremental investments and savings within Buildings Technology follows several different patterns. A few projects accelerate by about ten years the development and market penetration of 
technologies that might have been developed and deployed anyway. These include 3803 Refrigeration R\&D: Commercial Refrigeration, 3811 Appliances and Emerging Technologies R\&D: Heat Pump Water Heater, 3815 Appliances and Emerging Technologies R\&D: Gas Condensing Water Heater, 3816 Appliances and Emerging Technologies R\&D: Recessed Can Lights, 2114 Window Technologies: Electrochromic Windows, and 2115 Window Technologies: Superwindows. The actual pattern of investment and savings for any technology in Table 2.1 depends on four factors: 1) the size of the (usually growing) market at each point in time, 2) the penetration rate for the EERE technologies and practices, based on lifetime cost savings vis-à-vis conventional technology and the associated payback period for the investment, 3) increases in the efficiency of a dollar of incremental investment, based in turn on the sales-volume-based rate of decline in the price of the technology and the higher durability of the EERE technology, and 4) the market-transformation, crowding-out effects of one technology on market prospects of all of its potential competitors. Durability and price effects radically reduce replacement costs for a given amount of lighting services, leading to overall net investment savings after 2015, even as the market size and penetration (and energy savings) continue to grow.

The largest of the Building Technologies decision units is Emerging Technologies, a group comprising 17 individual projects with net savings (that is, allowing for ongoing investment) of $\$ 7.6$ billion by 2030 , about $47 \%$ of the total in all of the Building Technologies Program in that year. Emerging Technologies would generate a net 85,000 potential jobs and $\$ 1.24$ billion in earned income in 2030 , which are $52 \%$ of the jobs and $50 \%$ of the earned income generated by the Building Technologies Program as a whole. 
Table 2.2. Effect of Energy Savings from EERE Buildings-Related Programs on Potential National Employment

\begin{tabular}{|c|c|c|c|c|c|c|c|c|c|c|}
\hline \multirow[b]{2}{*}{ Projcode } & \multicolumn{10}{|c|}{ Effect on Total National Employment (Thousands of Jobs) } \\
\hline & 2004 & 2005 & 2006 & 2007 & 2008 & 2010 & 2015 & 2020 & 2025 & 2030 \\
\hline \multicolumn{11}{|l|}{ 1. Weatherization Assistance Program } \\
\hline \multicolumn{11}{|l|}{ 2. State Energy Program } \\
\hline 903 State Formula Grants & 0.3 & 0.4 & 0.7 & 0.9 & 1.1 & 1.5 & 2.6 & 3.3 & 3.3 & 3.4 \\
\hline 1332 Rebuild America & 0.1 & 0.2 & 0.3 & 0.4 & 0.6 & 0.9 & 1.2 & 1.2 & 1.3 & 1.3 \\
\hline 1336 Information Outreach & 1.3 & 1.5 & 2.3 & 2.2 & 2.2 & 2.1 & 2.2 & 2.2 & 2.2 & 2.3 \\
\hline 1338 Training and Technical Assistance & 0.5 & 0.7 & 1.3 & 1.9 & 2.6 & 5.0 & 14.7 & 24.7 & 33.0 & 40.9 \\
\hline 422 Energy Star & \multicolumn{10}{|c|}{ Details in $4221-4228$} \\
\hline 4225 Energy Star: Gas Water Heaters & 0.0 & 0.0 & 0.0 & 0.0 & 0.0 & 0.0 & 0.1 & 0.3 & 0.5 & 0.8 \\
\hline 4224 Energy Star: Room Air Cond & 0.0 & 0.0 & 0.1 & 0.1 & 0.1 & 0.1 & 0.2 & 0.3 & 0.4 & 0.5 \\
\hline 4228 Energy Star: CFLs & 0.4 & 0.7 & 1.4 & 2.4 & 3.7 & 7.1 & 22.8 & 44.6 & 55.1 & 56.8 \\
\hline 4222 Energy Star: Dishwashers & 0.0 & 0.0 & 0.1 & 0.1 & 0.1 & 0.1 & 0.2 & 0.3 & 0.5 & 0.7 \\
\hline \multicolumn{11}{|l|}{ 4. Residential Buildings Integration } \\
\hline 115 Res. Technology Research \& Development & 0.0 & 0.0 & 0.1 & 0.2 & 0.3 & 0.5 & 1.0 & 1.3 & 1.4 & 1.6 \\
\hline
\end{tabular}




\begin{tabular}{|c|c|c|c|c|c|c|c|c|c|c|c|}
\hline \multirow[b]{2}{*}{ Projcod } & \multirow[b]{2}{*}{ Descriptor } & \multicolumn{10}{|c|}{ Effect on Total National Employment (Thousands of Jobs) } \\
\hline & & \multirow{2}{*}{$\frac{2004}{0.0}$} & \multirow{2}{*}{$\begin{array}{r}2005 \\
0.0\end{array}$} & \multirow{2}{*}{$\begin{array}{r}2006 \\
0.0\end{array}$} & \multirow{2}{*}{$\begin{array}{r}2007 \\
0.0\end{array}$} & \multirow{2}{*}{$\frac{2008}{0.0}$} & \multirow{2}{*}{$\frac{2010}{0.0}$} & \multirow{2}{*}{$\frac{2015}{0.5}$} & \multirow{2}{*}{$\frac{2020}{1.4}$} & \multirow{2}{*}{$\frac{2025}{2.3}$} & \multirow{2}{*}{$\frac{2030}{3.4}$} \\
\hline 506 & Residential Building Codes & & & & & & & & & & \\
\hline \multicolumn{12}{|c|}{ 5. Commercial Buildings Integration } \\
\hline 124 & Com. Technology Development & 0.0 & 0.0 & 0.0 & 0.1 & 0.1 & 0.4 & 3.8 & 6.6 & 9.0 & 11.4 \\
\hline \multicolumn{12}{|c|}{ 6. Emerging Technologies } \\
\hline 430 & Lighting R\&D & \multicolumn{10}{|c|}{ Details in $4304-440$} \\
\hline 4304 & Lighting R\&D: Controls & 0.1 & 0.2 & 0.3 & 0.4 & 0.6 & 1.0 & 2.3 & 3.2 & 4.1 & 5.0 \\
\hline 440 & Next Generation Lighting Initiative & 0.0 & 0.0 & 0.0 & 0.0 & 0.0 & 0.0 & 0.0 & 3.6 & 8.0 & 13.4 \\
\hline 3803 & Refrigeration R\&D: Commercial Refrigeration & 0.0 & 0.1 & 0.1 & 0.2 & 0.3 & 0.6 & 2.1 & 2.7 & 1.3 & 0.2 \\
\hline 3804 & Refrigeration R\&D: Refrigerant Meter & 0.0 & 0.0 & 0.1 & 0.1 & 0.3 & 0.8 & 4.8 & 12.5 & 15.5 & 9.2 \\
\hline 381 & Appliances \& Emerging Technologies R\&D & \multicolumn{10}{|c|}{ Details in $3811-3817$} \\
\hline 3811 & Appliances \& Emerging Tech R\&D: HPWH & 0.2 & 0.2 & 0.4 & 0.6 & 1.0 & 2.1 & 5.2 & 6.4 & 7.8 & 9.4 \\
\hline 3813 & $\begin{array}{l}\text { Appliances \& Emerging Tech R\&D: Roof Top } \\
\text { AC }\end{array}$ & 0.0 & 0.0 & 0.1 & 0.1 & 0.1 & 0.2 & 0.2 & 0.3 & 0.3 & 0.4 \\
\hline 3815 & $\begin{array}{l}\text { Appliances \& Emerging Tech R\&D: Gas } \\
\text { Condensing WH }\end{array}$ & 0.0 & 0.0 & 0.0 & 0.0 & 0.1 & 0.2 & 0.6 & 0.8 & 0.9 & 1.1 \\
\hline 3816 & $\begin{array}{l}\text { Appliances \& Emerging Tech R\&D: Recessed } \\
\text { Can Lights }\end{array}$ & 0.0 & 0.0 & 0.1 & 0.1 & 0.3 & 0.8 & 2.6 & 3.3 & 3.4 & 3.4 \\
\hline
\end{tabular}




\begin{tabular}{|c|c|c|c|c|c|c|c|c|c|c|c|}
\hline \multirow[b]{2}{*}{ Projcode } & \multirow[b]{2}{*}{ Descriptor } & \multicolumn{10}{|c|}{ Effect on Total National Employment (Thousands of Jobs) } \\
\hline & & \multirow{2}{*}{$\begin{array}{r}2004 \\
0.3\end{array}$} & \multirow{2}{*}{$\frac{2005}{0.5}$} & \multirow{2}{*}{$\begin{array}{r}2006 \\
0.9\end{array}$} & \multirow{2}{*}{$\frac{2007}{1.5}$} & \multirow{2}{*}{$\begin{array}{r}2008 \\
2.0\end{array}$} & \multirow{2}{*}{$\frac{2010}{2.8}$} & \multirow{2}{*}{$\frac{2015}{0.3}$} & \multirow{2}{*}{$\frac{2020}{0.0}$} & \multirow{2}{*}{$\frac{2025}{0.0}$} & \multirow{2}{*}{$\begin{array}{r}2030 \\
0.0\end{array}$} \\
\hline 3817 & Appliances \& Emerging Tech R\&D: R-Lamp & & & & & & & & & & \\
\hline 2114 & Window Technologies: Electrochromic Windows & 0.7 & 0.6 & 0.8 & 1.0 & 1.2 & 1.8 & 3.0 & 4.7 & 6.6 & 8.7 \\
\hline 2115 & Window Technologies: Superwindows & 0.4 & 0.5 & 0.7 & 1.0 & 1.4 & 2.4 & 6.6 & 10.9 & 15.7 & 21.0 \\
\hline 2116 & Thermal Insulation: Quick Fill Walls & 0.0 & 0.0 & 0.0 & 0.0 & 0.0 & 0.0 & 0.1 & 0.2 & 0.4 & 0.5 \\
\hline 2117 & $\begin{array}{l}\text { Thermal Insulation: R30 Insulation/30 Year Life } \\
\text { Roofs }\end{array}$ & 0.0 & 0.0 & 0.0 & 0.0 & 0.0 & 0.0 & 0.2 & 0.5 & 0.9 & 1.3 \\
\hline 2118 & Thermal Insulation: Moisture/Wet Insulation & 0.0 & 0.0 & 0.1 & 0.1 & 0.1 & 0.3 & 0.8 & 1.7 & 2.8 & 3.9 \\
\hline \multicolumn{12}{|c|}{ 7. Equipment Standards and Analysis } \\
\hline 6043 & Standards: Res Gas Furnaces/Boilers & 0.0 & 0.0 & 0.0 & 0.0 & 0.0 & 0.1 & 0.5 & 1.0 & 1.4 & 1.9 \\
\hline 6044 & Standards: EPACT Standards & 0.0 & 0.2 & 0.5 & 0.7 & 1.7 & 4.0 & 11.2 & 18.8 & 21.9 & 25.0 \\
\hline 6039 & Standards: Distribution Transformers & 0.0 & 0.0 & 0.0 & 0.0 & 0.6 & 1.8 & 5.1 & 9.0 & 10.0 & 11.2 \\
\hline $\begin{array}{l}\text { Weatheriza } \\
\text { (DU 1-3) }\end{array}$ & ation and Intergovernmental Program & 4.5 & 5.6 & 8.7 & 11.4 & 14.8 & 23.6 & 56.3 & 94.3 & 118.0 & 133.0 \\
\hline Building Te & echnologies Program (DU 4-7) & 2.0 & 2.7 & 4.6 & 7.0 & 11.5 & 23.2 & 63.4 & 112.3 & 145.5 & 172.2 \\
\hline Total & & 6.5 & 8.3 & 13.3 & 18.4 & 26.3 & 46.8 & 119.7 & 206.6 & 263.5 & 305.2 \\
\hline
\end{tabular}


Table 2.3. Effect of Energy Savings from EERE Buildings-Related Programs on Potential National Earned Income

\begin{tabular}{|c|c|c|c|c|c|c|c|c|c|c|}
\hline \multirow[b]{2}{*}{ Descriptor } & \multicolumn{10}{|c|}{ Effect on Total National Earned Income (Million 2002\$) } \\
\hline & 2004 & 2005 & 2006 & 2007 & 2008 & 2010 & 2015 & 2020 & 2025 & 2030 \\
\hline \multicolumn{11}{|l|}{ 1. Weatherization Assistance } \\
\hline 901 Weatherization Assistance & 7.1 & 6.4 & 7.3 & 8.1 & 9.0 & 10.9 & 16.0 & 18.8 & 19.5 & 20.0 \\
\hline \multicolumn{11}{|l|}{ 2. State Energy Program } \\
\hline 903 State Formula Grants & 4.6 & 7.2 & 10.6 & 13.7 & 17.0 & 23.4 & 40.6 & 52.0 & 52.9 & 53.9 \\
\hline \multicolumn{11}{|l|}{ 3. Gateway Deployment } \\
\hline 1332 Rebuild America & 1.1 & 1.4 & 2.4 & 3.6 & 4.8 & 7.7 & 10.8 & 11.2 & 11.7 & 12.3 \\
\hline 1336 Information Outreach & 15.6 & 23.2 & 34.0 & 32.8 & 32.4 & 31.6 & 31.8 & 32.5 & 32.9 & 33.4 \\
\hline 1338 Training and Technical Assistance & 6.1 & 11.7 & 20.5 & 29.8 & 40.0 & 75.0 & 215.3 & 358.4 & 473.5 & 580.0 \\
\hline 422 Energy Star & \multicolumn{10}{|c|}{ Details in $4221-4228$} \\
\hline 4221 Energy Star: Clothes Washers & 8.6 & 7.1 & 9.0 & 10.7 & 12.4 & 16.0 & 22.6 & 27.8 & 33.8 & 40.5 \\
\hline 4223 Energy Star: Refrigerators & 0.4 & 0.8 & 1.7 & 2.8 & 3.8 & 6.0 & 11.3 & 15.6 & 20.4 & 26.1 \\
\hline 4226 Energy Star: Electric Water Heaters & 0.1 & 0.4 & 1.0 & 2.2 & 4.5 & 13.3 & 37.3 & 66.3 & 100.3 & 139.7 \\
\hline 4225 Energy Star: Gas Water Heaters & 0.0 & 0.0 & -0.1 & -0.2 & -0.3 & -0.6 & -1.6 & -3.9 & -6.5 & -9.3 \\
\hline 4224 Energy Star: Room Air Cond & 0.4 & 0.5 & 0.7 & 0.9 & 1.1 & 1.5 & 2.7 & 3.8 & 5.0 & 6.4 \\
\hline 4228 Energy Star: CFLs & 4.4 & 8.8 & 17.1 & 28.7 & 44.9 & 85.9 & 278.0 & 546.2 & 675.5 & 696.1 \\
\hline 4222 Energy Star: Dishwashers & 0.2 & 0.3 & 0.6 & 0.8 & 1.0 & 1.4 & 2.7 & 4.2 & 6.0 & 7.9 \\
\hline \multicolumn{11}{|l|}{ 4. Residential Buildings Integration } \\
\hline 115 Res. Technology Research \& Development & 0.1 & 0.2 & 0.5 & 0.8 & 1.3 & 2.4 & 5.2 & 7.0 & 7.8 & 8.6 \\
\hline 506 Residential Building Codes & 0.0 & 0.0 & 0.0 & 0.0 & 0.0 & 0.0 & 0.8 & 2.3 & 4.5 & 7.3 \\
\hline
\end{tabular}




\begin{tabular}{|c|c|c|c|c|c|c|c|c|c|c|c|}
\hline \multirow[b]{2}{*}{ Projcode } & \multirow[b]{2}{*}{ Descriptor } & \multicolumn{10}{|c|}{ Effect on Total National Earned Income (Million 2002\$) } \\
\hline & & 2004 & 2005 & 2006 & 2007 & 2008 & 2010 & 2015 & 2020 & 2025 & 2030 \\
\hline 116 & Zero Energy Buildings & 0.2 & 0.4 & 0.8 & 1.3 & 2.1 & 4.7 & 18.8 & 44.4 & 82.8 & 134.1 \\
\hline \multicolumn{12}{|c|}{ 5. Commercial Buildings Integration } \\
\hline 124 & Com. Technology Development & 0.0 & 0.3 & 0.6 & 0.9 & 1.7 & 6.6 & 58.4 & 104.5 & 143.9 & 183.9 \\
\hline 507 & Commercial Building Codes & 0.0 & 0.0 & 0.0 & 0.0 & 0.0 & 1.1 & 19.9 & 67.7 & 133.9 & 202.4 \\
\hline \multicolumn{12}{|c|}{ 6. Emerging Technologies } \\
\hline 430 & Lighting R\&D & \multicolumn{10}{|c|}{ Details in $4304-440$} \\
\hline 4304 & Lighting R\&D: Controls & 2.0 & 2.9 & 4.8 & 7.1 & 10.2 & 18.3 & 42.1 & 58.2 & 74.7 & 90.2 \\
\hline 440 & Next Generation Lighting Initiative & 0.0 & 0.0 & 0.0 & 0.0 & 0.0 & 0.0 & 0.0 & 65.3 & 145.2 & 243.0 \\
\hline & $\begin{array}{l}\text { Space Conditioning and Refrigeration } \\
\text { R\&D }\end{array}$ & \multicolumn{10}{|c|}{ Details in $3801-3804$} \\
\hline 3801 & $\begin{array}{l}\text { Refrigeration R\&D: Res. HVAC Dist. } \\
\text { System }\end{array}$ & 0.7 & 0.8 & 1.5 & 2.5 & 3.9 & 8.2 & 25.8 & 29.8 & 18.8 & 15.0 \\
\hline 3802 & Refrigeration R\&D: Adv. Elec HPWH & 0.0 & 0.1 & 0.3 & 0.6 & 1.2 & 3.5 & 22.6 & 59.6 & 75.7 & 48.4 \\
\hline 3803 & $\begin{array}{l}\text { Refrigeration R\&D: Commercial } \\
\text { Refrigeration }\end{array}$ & 0.5 & 1.0 & 1.9 & 3.1 & 4.9 & 10.7 & 37.6 & 46.8 & 22.2 & 4.4 \\
\hline 3804 & Refrigeration R\&D: Refrigerant Meter & 0.0 & 0.3 & 0.9 & 2.0 & 3.8 & 10.6 & 63.6 & 167.9 & 207.4 & 123.1 \\
\hline & $\begin{array}{l}\text { Appliances \& Emerging Technologies } \\
\text { R\&D }\end{array}$ & \multicolumn{10}{|c|}{ Details in $3811-3817$} \\
\hline 3811 & $\begin{array}{l}\text { Appliances \& Emerging Tech R\&D: } \\
\text { HPWH }\end{array}$ & 2.5 & 3.0 & 4.9 & 7.7 & 11.7 & 25.4 & 63.0 & 78.1 & 95.2 & 114.7 \\
\hline 3813 & $\begin{array}{l}\text { Appliances \& Emerging Tech R\&D: Roof } \\
\text { Top AC }\end{array}$ & 0.0 & 0.8 & 1.4 & 1.9 & 2.3 & 2.9 & 4.1 & 4.9 & 5.9 & 6.8 \\
\hline
\end{tabular}




\begin{tabular}{|c|c|c|c|c|c|c|c|c|c|c|c|}
\hline \multirow[b]{2}{*}{ Projcode } & \multirow[b]{2}{*}{ Descriptor } & \multicolumn{10}{|c|}{ Effect on Total National Earned Income (Million 2002\$) } \\
\hline & & 2004 & 2005 & 2006 & 2007 & 2008 & 2010 & 2015 & 2020 & 2025 & 2030 \\
\hline 3815 & $\begin{array}{l}\text { Appliances \& Emerging Tech R\&D: Gas } \\
\text { Condensing WH }\end{array}$ & 0.0 & -0.1 & -0.2 & -0.4 & -0.8 & -2.6 & -7.8 & -9.6 & -11.4 & -13.3 \\
\hline 3816 & $\begin{array}{l}\text { Appliances \& Emerging Tech R\&D: } \\
\text { Recessed Can Lights }\end{array}$ & 0.1 & 0.3 & 0.8 & 1.8 & 3.6 & 10.1 & 31.8 & 40.6 & 40.9 & 41.2 \\
\hline 3817 & $\begin{array}{l}\text { Appliances \& Emerging Tech R\&D: R- } \\
\text { Lamp }\end{array}$ & 2.9 & 5.8 & 11.2 & 17.9 & 24.2 & 34.6 & 3.6 & 0.0 & 0.0 & 0.0 \\
\hline 2111 & $\begin{array}{l}\text { Building Envelope R\&D: Window } \\
\text { Technologies }\end{array}$ & \multicolumn{10}{|c|}{ Details in $2114-2115$} \\
\hline 2114 & $\begin{array}{l}\text { Window Technologies: Electrochromic } \\
\text { Windows }\end{array}$ & 10.3 & 11.7 & 15.5 & 19.2 & 23.3 & 33.0 & 56.6 & 87.0 & 120.7 & 158.9 \\
\hline 2115 & Window Technologies: Superwindows & 1.7 & 1.4 & 2.3 & 3.3 & 4.7 & 8.5 & 24.5 & 41.2 & 61.9 & 86.8 \\
\hline 2112 & $\begin{array}{l}\text { Building Envelope R\&D: Thermal } \\
\text { Insulation \& Building Materials }\end{array}$ & \multicolumn{10}{|c|}{ Details in 2116-2118, 145} \\
\hline 2116 & Thermal Insulation: Quick Fill Walls & 0.0 & 0.0 & 0.0 & 0.0 & 0.0 & 0.0 & -0.1 & -0.3 & -0.4 & -0.5 \\
\hline 2117 & $\begin{array}{l}\text { Thermal Insulation: R30 Insulation/30 } \\
\text { Year Life Roofs }\end{array}$ & 0.0 & 0.0 & 0.0 & 0.0 & 0.0 & 0.1 & 1.2 & 3.3 & 5.7 & 8.4 \\
\hline 2118 & $\begin{array}{l}\text { Thermal Insulation: Moisture/Wet } \\
\text { Insulation }\end{array}$ & -0.1 & -0.2 & -0.5 & -0.9 & -1.3 & -2.3 & -4.4 & -6.6 & -8.6 & -10.6 \\
\hline 145 & Analysis Tools and Design & 0.2 & 0.4 & 0.7 & 1.1 & 1.6 & 3.9 & 19.9 & 46.3 & 77.7 & 109.7 \\
\hline \multicolumn{12}{|c|}{ 7. Equipment Standards and Analysis } \\
\hline 603 & Equipment Standards and Analysis & \multicolumn{10}{|c|}{ Details in 6039-6044 } \\
\hline 6043 & Standards: Res Gas Furnaces/Boilers & 0.0 & 0.0 & 0.0 & 0.0 & 0.0 & -1.8 & -6.6 & -11.8 & -17.6 & -24.0 \\
\hline 6044 & Standards: EPACT Standards & 0.0 & 4.0 & 8.2 & 12.0 & 30.8 & 71.5 & 199.7 & 334.8 & 387.3 & 441.9 \\
\hline
\end{tabular}




\begin{tabular}{|c|c|c|c|c|c|c|c|c|c|c|}
\hline \multirow[b]{2}{*}{ Descriptor } & \multicolumn{10}{|c|}{ Effect on Total National Earned Income (Million 2002\$) } \\
\hline & 2004 & 2005 & 2006 & 2007 & 2008 & 2010 & 2015 & 2020 & 2025 & 2030 \\
\hline Standards: Distribution Transformers & 0.0 & 0.0 & 0.0 & 0.0 & 11.1 & 33.1 & 93.1 & 162.4 & 181.0 & 201.8 \\
\hline $\begin{array}{l}\text { Weatherization and Intergovernmental Program } \\
\text { (DU 1-3) }\end{array}$ & 48.6 & 67.9 & 104.7 & 133.9 & 170.7 & 272.3 & 667.4 & $1,132.7$ & $1,424.9$ & $1,606.9$ \\
\hline Building Technologies Program (DU 4-7) & 21.2 & 33.0 & 55.5 & 81.9 & 140.4 & 282.5 & 773.4 & $1,424.0$ & $1,855.2$ & $2,182.2$ \\
\hline Total & 69.8 & 100.9 & 160.2 & 215.8 & 311.1 & 554.8 & $1,440.8$ & $2,556.8$ & $3,280.1$ & $3,789.1$ \\
\hline
\end{tabular}


Table 2.4. Effect of the Full Investment Scenario on Potential National Employment

\begin{tabular}{|c|c|c|c|c|c|c|c|c|c|c|c|}
\hline \multirow[b]{2}{*}{ Projcode } & \multirow[b]{2}{*}{ Descriptor } & \multicolumn{10}{|c|}{ Effect on Total National Employment (Thousands of Jobs) } \\
\hline & & 2004 & 2005 & 2006 & 2007 & 2008 & 2010 & 2015 & 2020 & 2025 & 2030 \\
\hline \multicolumn{12}{|c|}{ 1. Weatherization Assistance Program } \\
\hline 901 & Weatherization Assistance & 0.5 & 0.8 & 1.2 & 1.6 & 2.0 & 2.8 & 4.9 & 6.3 & 6.4 & 6.5 \\
\hline \multicolumn{12}{|c|}{ 2. State Energy Program } \\
\hline 903 & State Formula Grants & 0.2 & 0.3 & 0.5 & 0.7 & 0.9 & 1.3 & 2.4 & 3.1 & 3.2 & 3.3 \\
\hline \multicolumn{12}{|c|}{ 3. Gateway Deployment } \\
\hline 1332 & Rebuild America & 0.1 & 0.1 & 0.2 & 0.3 & 0.5 & 0.8 & 1.2 & 1.2 & 1.2 & 1.3 \\
\hline 1336 & Information Outreach & 1.2 & 1.5 & 2.2 & 2.2 & 2.1 & 2.1 & 2.1 & 2.2 & 2.2 & 2.2 \\
\hline 1338 & Training and Technical Assistance & 0.4 & 0.7 & 1.2 & 1.8 & 2.5 & 4.8 & 14.5 & 24.4 & 32.8 & 40.6 \\
\hline 422 & Energy Star & \multicolumn{10}{|c|}{ Details in $4221-4228$} \\
\hline 4221 & Energy Star: Clothes Washers & 0.6 & 0.4 & 0.7 & 0.9 & 1.2 & 1.7 & 2.5 & 3.4 & 4.3 & 5.4 \\
\hline 4223 & Energy Star: Refrigerators & 0.0 & -0.1 & -0.1 & -0.1 & 0.0 & 0.1 & 0.6 & 0.9 & 1.3 & 1.7 \\
\hline 4226 & Energy Star: Electric Water Heaters & 0.0 & 0.0 & 0.1 & 0.2 & 0.3 & 1.0 & 3.0 & 5.4 & 8.2 & 11.4 \\
\hline 4225 & Energy Star: Gas Water Heaters & 0.0 & 0.0 & 0.0 & 0.0 & 0.0 & 0.0 & 0.1 & 0.3 & 0.5 & 0.7 \\
\hline 4224 & Energy Star: Room Air Cond & -0.1 & -0.1 & -0.1 & -0.1 & 0.0 & 0.0 & 0.1 & 0.2 & 0.2 & 0.4 \\
\hline 4228 & Energy Star: CFLs & 0.4 & 0.7 & 1.4 & 2.3 & 3.7 & 7.0 & 22.9 & 45.2 & 56.5 & 59.1 \\
\hline 4222 & Energy Star: Dishwashers & 0.0 & 0.0 & 0.0 & 0.0 & 0.0 & 0.1 & 0.2 & 0.3 & 0.4 & 0.6 \\
\hline \multicolumn{12}{|c|}{ 4. Residential Buildings Integration } \\
\hline 115 & Res. Technology Research \& Development & 0.0 & 0.0 & 0.0 & 0.1 & 0.2 & 0.4 & 1.0 & 1.3 & 1.4 & 1.6 \\
\hline 506 & Residential Building Codes & 0.0 & 0.0 & 0.0 & 0.0 & 0.0 & 0.0 & 0.4 & 1.2 & 2.2 & 3.2 \\
\hline
\end{tabular}




\begin{tabular}{|c|c|c|c|c|c|c|c|c|c|c|c|}
\hline \multirow[b]{2}{*}{ Projcode } & \multirow[b]{2}{*}{ Descriptor } & \multicolumn{10}{|c|}{ Effect on Total National Employment (Thousands of Jobs) } \\
\hline & & 2004 & 2005 & 2006 & 2007 & 2008 & 2010 & 2015 & 2020 & 2025 & 2030 \\
\hline 116 & Zero Energy Buildings & 0.0 & 0.0 & 0.0 & 0.1 & 0.2 & 0.4 & 2.0 & 5.0 & 9.4 & 15.4 \\
\hline \multicolumn{12}{|c|}{ 5. Commercial Buildings Integration } \\
\hline 124 & Com. Technology Development & 0.0 & 0.0 & 0.0 & 0.1 & 0.1 & 0.4 & 3.8 & 6.6 & 9.0 & 11.4 \\
\hline 507 & Commercial Building Codes & 0.0 & 0.0 & 0.0 & 0.0 & 0.0 & 0.0 & 1.0 & 3.5 & 7.0 & 10.7 \\
\hline \multicolumn{12}{|c|}{ 6. Emerging Technologies } \\
\hline 430 & Lighting R\&D & \multicolumn{10}{|c|}{ Details in $4304-440$} \\
\hline 4304 & Lighting R\&D: Controls & 0.0 & 0.1 & 0.2 & 0.2 & 0.4 & 0.7 & 2.1 & 3.1 & 3.9 & 4.8 \\
\hline 440 & Next Generation Lighting Initiative & 0.0 & 0.0 & 0.0 & 0.0 & 0.0 & 0.0 & 0.0 & 3.6 & 8.0 & 13.3 \\
\hline 380 & Space Conditioning and Refrigeration R\&D & \multicolumn{10}{|c|}{ Details in 3801-3804 } \\
\hline 3801 & Refrigeration R\&D: Res. HVAC Dist. System & 0.2 & 0.3 & 0.5 & 0.8 & 1.2 & 2.4 & 6.5 & 6.8 & 4.0 & 2.7 \\
\hline 3802 & Refrigeration R\&D: Adv. Elec HPWH & 0.0 & 0.0 & 0.0 & 0.0 & 0.1 & 0.3 & 1.8 & 4.8 & 6.2 & 4.0 \\
\hline 3803 & Refrigeration R\&D: Commercial Refrigeration & 0.0 & 0.0 & 0.1 & 0.2 & 0.2 & 0.5 & 2.0 & 2.7 & 1.4 & 0.3 \\
\hline 3804 & Refrigeration R\&D: Refrigerant Meter & 0.0 & 0.0 & 0.0 & 0.1 & 0.2 & 0.7 & 4.3 & 11.8 & 15.1 & 9.1 \\
\hline 381 & Appliances \& Emerging Technologies R\&D & \multicolumn{10}{|c|}{ Details in $3811-3817$} \\
\hline 3811 & Appliances \& Emerging Tech R\&D: HPWH & 0.2 & 0.2 & 0.4 & 0.6 & 0.9 & 2.0 & 5.1 & 6.4 & 7.8 & 9.4 \\
\hline 3813 & $\begin{array}{l}\text { Appliances \& Emerging Tech R\&D: Roof Top } \\
\text { AC }\end{array}$ & 0.0 & 0.0 & 0.1 & 0.1 & 0.1 & 0.2 & 0.2 & 0.3 & 0.3 & 0.4 \\
\hline 3815 & $\begin{array}{l}\text { Appliances \& Emerging Tech R\&D: Gas } \\
\text { Condensing WH }\end{array}$ & 0.0 & 0.0 & 0.0 & 0.0 & 0.1 & 0.2 & 0.6 & 0.8 & 0.9 & 1.1 \\
\hline 3816 & $\begin{array}{l}\text { Appliances \& Emerging Tech R\&D: Recessed } \\
\text { Can Lights }\end{array}$ & 0.0 & 0.0 & 0.0 & 0.1 & 0.2 & 0.7 & 2.5 & 3.4 & 3.4 & 3.4 \\
\hline 3817 & Appliances \& Emerging Tech R\&D: R-Lamp & 0.3 & 0.5 & 0.9 & 1.5 & 2.0 & 2.9 & 0.4 & 0.1 & 0.1 & 0.1 \\
\hline
\end{tabular}




\begin{tabular}{|c|c|c|c|c|c|c|c|c|c|c|c|}
\hline \multirow[b]{2}{*}{ Projcode } & \multirow[b]{2}{*}{ Descriptor } & \multicolumn{10}{|c|}{ Effect on Total National Employment (Thousands of Jobs) } \\
\hline & & 2004 & 2005 & 2006 & 2007 & 2008 & 2010 & 2015 & 2020 & 2025 & 2030 \\
\hline 2111 & $\begin{array}{l}\text { Building Envelope R\&D: Window } \\
\text { Technologies }\end{array}$ & \multicolumn{10}{|c|}{ Details in $2114-2115$} \\
\hline 2114 & $\begin{array}{l}\text { Window Technologies: Electrochromic } \\
\text { Windows }\end{array}$ & 0.4 & 0.3 & 0.5 & 0.7 & 0.8 & 1.3 & 2.6 & 4.1 & 5.9 & 7.9 \\
\hline 2115 & Window Technologies: Superwindows & -0.3 & -0.4 & -0.3 & -0.3 & -0.2 & 0.1 & 2.9 & 8.1 & 11.7 & 16.6 \\
\hline 2112 & $\begin{array}{l}\text { Building Envelope R\&D: Thermal Insulation } \\
\& \text { Building Materials }\end{array}$ & \multicolumn{10}{|c|}{ Details in $2116-2118,145$} \\
\hline 2116 & Thermal Insulation: Quick Fill Walls & 0.0 & 0.0 & 0.0 & 0.0 & 0.0 & 0.0 & 0.1 & 0.2 & 0.4 & 0.6 \\
\hline 2117 & $\begin{array}{l}\text { Thermal Insulation: R30 Insulation/30 Year } \\
\text { Life Roofs }\end{array}$ & 0.0 & 0.0 & 0.0 & 0.0 & 0.0 & 0.0 & 0.2 & 0.5 & 0.9 & 1.3 \\
\hline 2118 & Thermal Insulation: Moisture/Wet Insulation & 0.0 & 0.0 & 0.0 & 0.0 & 0.0 & 0.1 & 0.6 & 1.4 & 2.4 & 3.5 \\
\hline 145 & Analysis Tools and Design & 0.0 & 0.0 & 0.0 & 0.1 & 0.1 & 0.2 & 1.2 & 2.8 & 4.7 & 6.7 \\
\hline \multicolumn{12}{|c|}{ 7. Equipment Standards and Analysis } \\
\hline 603 & Equipment Standards and Analysis & \multicolumn{10}{|c|}{ Details in 6039-6044 } \\
\hline 6043 & Standards: Res Gas Furnaces/Boilers & 0.0 & 0.0 & 0.0 & 0.0 & 0.0 & 0.1 & 0.5 & 1.0 & 1.4 & 1.9 \\
\hline 6044 & Standards: EPACT Standards & 0.0 & 0.0 & 0.2 & 0.4 & 0.6 & 2.8 & 9.7 & 17.2 & 21.2 & 24.3 \\
\hline 6039 & Standards: Distribution Transformers & 0.0 & 0.0 & 0.0 & 0.0 & -1.2 & 0.0 & 3.1 & 6.5 & 9.3 & 10.4 \\
\hline $\begin{array}{l}\text { Weatheriz } \\
\text { (DU 1-3) }\end{array}$ & zation and Intergovernmental Program & 3.3 & 4.0 & 6.9 & 9.5 & 12.9 & 21.5 & 54.2 & 92.6 & 117.1 & 132.9 \\
\hline Building T & Technologies Program (DU 4-7) & 0.9 & 1.2 & 2.7 & 4.8 & 6.0 & 16.7 & 54.4 & 103.1 & 138.1 & 164.2 \\
\hline Total & & 4.2 & 5.2 & 9.7 & 14.4 & 18.9 & 38.2 & 108.6 & 195.7 & 255.1 & 297.1 \\
\hline
\end{tabular}


Table 2.5. Effect of the Full Investment Scenario on Potential National Earned Income

\begin{tabular}{|c|c|c|c|c|c|c|c|c|c|c|c|}
\hline \multirow[b]{2}{*}{ Projcode } & \multirow[b]{2}{*}{ Descriptor } & \multicolumn{10}{|c|}{ Effect on Total National Earned Income (Million 2002\$) } \\
\hline & & 2004 & 2005 & 2006 & 2007 & 2008 & 2010 & 2015 & 2020 & 2025 & 2030 \\
\hline \multicolumn{12}{|c|}{ 1. Weatherization Assistance Program } \\
\hline \multicolumn{12}{|c|}{ 2. State Energy Program } \\
\hline 903 & State Formula Grants & 9.6 & 12.2 & 15.6 & 18.7 & 22.0 & 28.4 & 45.6 & 56.9 & 57.9 & 58.9 \\
\hline 1332 & Rebuild America & 15.2 & 15.3 & 23.0 & 30.8 & 31.7 & 41.8 & 13.7 & 13.9 & 14.3 & 14.9 \\
\hline 1336 & Information Outreach & 26.1 & 33.2 & 43.8 & 42.8 & 42.2 & 41.3 & 41.4 & 42.6 & 43.2 & 43.6 \\
\hline 1338 & Training and Technical Assistance & 15.3 & 23.9 & 35.5 & 47.3 & 61.6 & 121.6 & 278.4 & 417.1 & 523.7 & 633.8 \\
\hline 422 & Energy Star & \multicolumn{10}{|c|}{ Details in $4221-4228$} \\
\hline 4221 & Energy Star: Clothes Washers & 20.7 & 21.2 & 23.2 & 25.0 & 26.9 & 30.7 & 40.2 & 46.3 & 53.2 & 60.9 \\
\hline 4225 & Energy Star: Gas Water Heaters & 0.0 & 0.5 & 0.8 & 1.1 & 1.6 & 1.9 & 3.6 & 1.7 & -0.5 & -2.9 \\
\hline 4224 & Energy Star: Room Air Cond & 12.4 & 19.1 & 19.4 & 19.6 & 19.5 & 19.5 & 24.0 & 25.9 & 28.0 & 30.4 \\
\hline 4228 & Energy Star: CFLs & 5.5 & 10.2 & 18.6 & 30.1 & 46.0 & 87.2 & 271.2 & 513.9 & 602.1 & 577.9 \\
\hline 4222 & Energy Star: Dishwashers & 3.2 & 5.9 & 6.2 & 6.3 & 6.6 & 7.3 & 9.2 & 11.0 & 13.1 & 15.4 \\
\hline \multicolumn{12}{|c|}{ 4. Residential Buildings Integration } \\
\hline 115 & $\begin{array}{l}\text { Res. Technology Research \& } \\
\text { Development }\end{array}$ & 1.5 & 2.6 & 4.6 & 5.1 & 6.8 & 8.7 & 8.8 & 8.3 & 9.1 & 9.9 \\
\hline
\end{tabular}




\begin{tabular}{|c|c|c|c|c|c|c|c|c|c|c|c|}
\hline Projcode & Descriptor & \multicolumn{10}{|c|}{ Effect on Total National Earned Income (Million 2002\$) } \\
\hline 506 & Residential Building Codes & 0.0 & 0.0 & 0.0 & 0.0 & 0.1 & 0.8 & 5.1 & 8.1 & 10.7 & 14.0 \\
\hline \multicolumn{12}{|c|}{ 5. Commercial Buildings Integration } \\
\hline 124 & Com. Technology Development & 0.0 & 0.3 & 0.6 & 0.9 & 1.7 & 6.6 & 58.4 & 104.5 & 143.9 & 183.9 \\
\hline \multicolumn{12}{|c|}{ 6. Emerging Technologies } \\
\hline 430 & Lighting R\&D & \multicolumn{10}{|c|}{ Details in $4304-440$} \\
\hline 4304 & Lighting R\&D: Controls & 0.9 & 2.1 & 3.6 & 5.6 & 8.2 & 15.5 & 39.3 & 56.5 & 72.6 & 88.2 \\
\hline 440 & Next Generation Lighting Initiative & 0.0 & 0.0 & 0.0 & 0.0 & 0.0 & 0.0 & 0.0 & 66.8 & 148.4 & 247.9 \\
\hline 3802 & Refrigeration R\&D: Adv. Elec HPWH & 0.0 & 0.2 & 0.5 & 1.0 & 1.8 & 4.8 & 28.8 & 68.5 & 81.5 & 49.8 \\
\hline 3803 & $\begin{array}{l}\text { Refrigeration R\&D: Commercial } \\
\text { Refrigeration }\end{array}$ & 0.9 & 1.6 & 2.7 & 4.2 & 6.5 & 13.6 & 42.3 & 45.7 & 17.0 & 2.7 \\
\hline 3804 & Refrigeration R\&D: Refrigerant Meter & 0.0 & 0.4 & 1.3 & 2.8 & 5.1 & 13.7 & 76.3 & 185.8 & 216.9 & 125.1 \\
\hline 381 & $\begin{array}{l}\text { Appliances \& Emerging Technologies } \\
\text { R\&D }\end{array}$ & \multicolumn{10}{|c|}{ Details in 3811-3817 } \\
\hline 3811 & $\begin{array}{l}\text { Appliances \& Emerging Tech R\&D: } \\
\text { HPWH }\end{array}$ & 4.2 & 4.1 & 6.6 & 10.2 & 15.1 & 32.2 & 67.5 & 82.7 & 100.0 & 119.6 \\
\hline
\end{tabular}




\begin{tabular}{|c|c|c|c|c|c|c|c|c|c|c|c|}
\hline \multirow[b]{2}{*}{ Projcode } & \multirow[b]{2}{*}{ Descriptor } & \multicolumn{10}{|c|}{ Effect on Total National Earned Income (Million 2002\$) } \\
\hline & & 2004 & 2005 & 2006 & 2007 & 2008 & 2010 & 2015 & 2020 & 2025 & 2030 \\
\hline 3813 & $\begin{array}{l}\text { Appliances \& Emerging Tech R\&D: Roof } \\
\text { Top AC }\end{array}$ & 0.0 & 1.5 & 2.0 & 2.4 & 2.8 & 3.3 & 4.6 & 5.4 & 6.3 & 7.2 \\
\hline 3815 & $\begin{array}{l}\text { Appliances \& Emerging Tech R\&D: Gas } \\
\text { Condensing WH }\end{array}$ & 0.0 & 0.1 & 0.0 & -0.1 & -0.2 & -1.5 & -7.8 & -9.6 & -11.3 & -13.2 \\
\hline 3816 & $\begin{array}{l}\text { Appliances \& Emerging Tech R\&D: } \\
\text { Recessed Can Lights }\end{array}$ & 0.1 & 0.6 & 1.6 & 3.4 & 6.2 & 14.0 & 35.4 & 38.6 & 38.7 & 38.9 \\
\hline 3817 & $\begin{array}{l}\text { Appliances \& Emerging Tech R\&D: R- } \\
\text { Lamp }\end{array}$ & 3.5 & 6.5 & 11.8 & 18.1 & 24.5 & 33.2 & -0.1 & -4.2 & -4.4 & -4.4 \\
\hline 2111 & $\begin{array}{l}\text { Building Envelope R\&D: Window } \\
\text { Technologies }\end{array}$ & \multicolumn{10}{|c|}{ Details in $2114-2115$} \\
\hline 2114 & $\begin{array}{l}\text { Window Technologies: Electrochromic } \\
\text { Windows }\end{array}$ & 17.3 & 19.4 & 24.9 & 27.9 & 33.5 & 45.8 & 68.2 & 104.0 & 139.5 & 179.9 \\
\hline 2115 & Window Technologies: Superwindows & 26.6 & 31.4 & 38.8 & 49.4 & 62.7 & 92.6 & 157.9 & 140.0 & 202.1 & 240.9 \\
\hline 2112 & $\begin{array}{l}\text { Building Envelope R\&D: Thermal } \\
\text { Insulation \& Building Materials }\end{array}$ & \multicolumn{10}{|c|}{ Details in $2116-2118,145$} \\
\hline 2116 & Thermal Insulation: Quick Fill Walls & 0.0 & 0.2 & 0.0 & 0.1 & 0.2 & 0.3 & 0.9 & 1.1 & 1.1 & 1.1 \\
\hline 2117 & $\begin{array}{l}\text { Thermal Insulation: R30 Insulation/30 } \\
\text { Year Life Roofs }\end{array}$ & 0.0 & 0.0 & 0.0 & 0.0 & 0.0 & 0.1 & 1.2 & 3.3 & 5.7 & 8.4 \\
\hline 2118 & $\begin{array}{l}\text { Thermal Insulation: Moisture/Wet } \\
\text { Insulation }\end{array}$ & 0.7 & 1.1 & 1.4 & 2.0 & 2.5 & 2.7 & 5.0 & 4.0 & 3.1 & 2.1 \\
\hline 145 & Analysis Tools and Design & 0.2 & 0.4 & 0.7 & 1.1 & 1.6 & 3.9 & 19.9 & 46.3 & 77.7 & 109.7 \\
\hline \multicolumn{12}{|c|}{ 7. Equipment Standards and Analysis } \\
\hline 603 & Equipment Standards and Analysis & \multicolumn{10}{|c|}{ Details in 6039-6044 } \\
\hline
\end{tabular}




\begin{tabular}{|c|c|c|c|c|c|c|c|c|c|c|c|}
\hline Projcode & Descriptor & \multicolumn{10}{|c|}{ Effect on Total National Earned Income (Million 2002\$) } \\
\hline 6043 & Standards: Res Gas Furnaces/Boilers & 0.0 & 0.0 & 0.0 & 0.0 & 0.0 & -1.3 & -6.4 & -11.7 & -17.5 & -24.0 \\
\hline 6039 & Standards: Distribution Transformers & 0.0 & 0.0 & 0.0 & 0.0 & -10.4 & 12.0 & 68.9 & 134.1 & 173.4 & 193.5 \\
\hline \multicolumn{2}{|c|}{$\begin{array}{l}\text { Weatherization and Intergovernmental Program } \\
\text { (DU 1-3) }\end{array}$} & 153.9 & 192.9 & 244.7 & 290.8 & 333.8 & 473.6 & 857.0 & $1,296.2$ & $1,542.3$ & $1,686.8$ \\
\hline \multicolumn{2}{|c|}{ Building Technologies Program (DU 4-7) } & 63.1 & 97.2 & 135.8 & 178.6 & 282.5 & 488.9 & $1,083.5$ & $1,677.1$ & $2,126.8$ & $2,474.8$ \\
\hline Total & & 217.0 & 290.1 & 380.6 & 469.5 & 616.3 & 962.5 & $1,940.4$ & $2,973.3$ & $3,669.2$ & $4,161.6$ \\
\hline
\end{tabular}




\subsection{Summary of Impacts}

The improvements in energy efficiency expected from EERE's buildings-related programs require a significant capital expense of just under $\$ 3$ billion to over $\$ 9$ billion per year to achieve, as shown in Table 2.1. (The peak investment year is actually 2015, with an expenditure of almost $\$ 10$ billion, as shown in appendix table A.1.) Initially, this annual investment is larger than the annual savings.

However, because the stock of energy efficient equipment and practices continues to grow, the annual savings eventually outstrip the investment. By 2030 the energy savings alone, as shown in Table 2.1, are $\$ 38$ billion per year, a significant national benefit. This does not count other obvious benefits, such as operational savings due to improved durability and efficiency of equipment, improved environmental quality from reduced burning of fossil fuels, and improved livability and increased value of structures. The impacts presented in Tables 2.2 through 2.5 illustrate the growing importance of energy efficiency through time to the U.S. economy as a result of these savings. Before 2010, the positive impacts are about 19,000 jobs and $\$ 600$ million in earnings, but by 2030 the impacts grow to around 300,000 jobs and over $\$ 4$ billion, roughly an order of magnitude larger. 



\subsection{References}

Anderson DM, DB Belzer, KA Cort, JA Dirks, DB Elliott, DJ Hostick, and MJ Scott. 2003. Methodological Framework for Analysis GPRA Metrics: Application to FY04 Projects in BT and WIP. PNNL-14231, Pacific Northwest National Laboratory, Richland, Washington.

Bureau of Economic Analysis. 1992. Regional Multipliers: A User Handbookfor the Regional Input-Output Modeling System (RIMS II). U.S. Department of Commerce, Washington, D.C.

Energy Information Administration (EIA). 2002. Assumptions to the Annual Energy Outlook 2002. DOE/EIA-0554(2002), Energy Information Administration, U.S. Department of Energy, Washington, D.C.

Energy Information Administration (EIA). 1996. Natural Gas 1996: Issues and Trends. DOE/EIA-0560(96), Energy Information Administration, U.S. Department of Energy, Washington, D.C.

Energy Information Administration (EIA). 1999. Natural Gas 1998: Issues and Trends. DOE/EIA-0560(98), Energy Information Administration, U.S. Department of Energy, Washington, D.C.

Minnesota IMPLAN Group, Inc. 1997. IMPLAN Professional: Social Accounting and Impact Analysis Software. Minnesota IMPLAN Group, Inc., Stillwater, Minnesota.

National Research Council, Board on Energy and Environmental Systems, Committee on Benefits of DOE R\&D on Energy Efficiency and Fossil Energy (NRC). 2001. Energy Efficiency and Fossil Energy Research at DOE: Was It Worth It? National Academies Press, Washington D.C.

Scott MJ, JM Roop, and RW Schultz. 2002. ImBuild II: Impact of Building Energy Efficiency Programs. PNNL-13926, Pacific Northwest National Laboratory, Richland, Washington. 



\section{Appendix}

\section{Detailed Calculations on EERE Buildings-Related Projects}





\section{Appendix}

\section{Detailed Calculations on EERE Buildings-Related Projects}

\section{Table Notes}

Table A.1: This table shows the effects of individual EERE buildings-related projects (identified by their 2004 GPRA project codes and titles) on national incremental investment in energy-efficient technology or practices in individual years. Current investment spending is reported each year because current investment spending affects current employment and earned income. Also shown for each year and project are the effects of the accumulated investments on current expenditures for oil, natural gas, and electricity. (Impacts on non-energy expenditures for items such as maintenance services generally have not been estimated and are not shown.) Current spending affects current employment and earned income. In some cases (such as the 124-Commercial Buildings Research and Development), the project is not expected to require any investment over and above current conventional practice, so the net effect on investment spending (and employment and income) is shown as zero. In most cases, the investment is expected to reduce net fuel expenditure, but sometimes consumption of one fuel will be altered by the change in consumption of another, resulting in an increased expenditure for that fuel. Thus, for example, for Project Code 6043, Standards for Residential Gas Furnaces and Boilers, Table A.1 shows the nation spending \$468 million less for gas for the residential sector, but spending slightly more for residential oil and electricity in the year 2030 than it otherwise would have; because it is adopting some oil and electric equipment in place of the increasingly-costly gas equipment. Project 2114, Electrochromic Windows, shows significant electricity savings in commercial buildings for cooling, but additional natural gas and oil is required to provide heating during the winter. Project 4228, Energy Star CFLs, reduces consumption of electricity for building lighting and cooling, but increases natural gas and oil for heating.

Table A.2: Purchases from different industrial sectors of the economy are associated with different interindustry sales of goods and services and different requirements for labor (e.g., an increase in purchases of plastic-framed efficient windows will not have an identical impact to increased purchases of more efficient refrigerators; because the production processes and materials used are different). Therefore, to estimate the impact of a given investment, the investment must be allocated to the sectors from which the investing business or household buys equipment and services. This table shows how the incremental investment premium associated with each EERE buildings-related project is assumed to be distributed among industrial sectors. The assumed allocation in each case was made in consultation with the GPRA researchers, based on project information provided by DOE project managers, as well as the characteristics of the technologies that are expected to be adopted as a result of the project. For example, the Weatherization Assistance Program is expected to result in incremental investments, divided one-half

for incremental residential construction equipment costs, and one-half for a variety of sectors that produce the building materials that would be used in weatherization. The latter are allocated $8.3 \%$ for each sector. A different kind of example is Energy Star Clothes Washers, where the entire incremental investment is allocated to Household Laundry Equipment (the industrial sector that builds clothes washing machines). Because no incremental installation cost or retail markup is expected on these units, the entire premium results from the fact that these units are expected to be more expensive to manufacture than with the conventional technology. 
Table A.1. EERE Buildings-Related Project Investment Costs and Energy Savings, by Year (Million \$2002)

\begin{tabular}{|c|c|c|c|c|c|c|c|c|c|c|}
\hline \multirow[b]{2}{*}{ Project and Category } & \multicolumn{10}{|c|}{ Fiscal Year } \\
\hline & 2004 & 2005 & 2006 & 2007 & 2008 & 2010 & 2015 & 2020 & 2025 & 2030 \\
\hline \multicolumn{11}{|l|}{ 1. Weatherization Assistance } \\
\hline \multicolumn{11}{|l|}{901 Weatherization Assistance } \\
\hline Investment & $\$ 535.7$ & $\$ 531.6$ & $\$ 538.8$ & $\$ 546.2$ & $\$ 553.8$ & $\$ 569.5$ & $\$ 577.6$ & $\$ 577.6$ & $\$ 577.6$ & $\$ 577.6$ \\
\hline Expenditures on Oil, Residential & $-\$ 16.0$ & $-\$ 31.5$ & $-\$ 46.8$ & $-\$ 63.4$ & $-\$ 79.9$ & $-\$ 114.0$ & $-\$ 205.3$ & $-\$ 264.7$ & $-\$ 275.1$ & $-\$ 283.8$ \\
\hline Expenditures on Oil, Commercial & $\$ 0.0$ & $\$ 0.0$ & $\$ 0.0$ & $\$ 0.0$ & $\$ 0.0$ & $\$ 0.0$ & $\$ 0.0$ & $\$ 0.0$ & $\$ 0.0$ & $\$ 0.0$ \\
\hline Expenditures on Natural Gas, Residential & $-\$ 34.7$ & $-\$ 68.1$ & $-\$ 101.8$ & $-\$ 135.6$ & $-\$ 169.5$ & $-\$ 236.8$ & $-\$ 405.1$ & $-\$ 519.1$ & $-\$ 524.2$ & $-\$ 525.0$ \\
\hline Expenditures on Natural Gas, Commercial & $\$ 0.0$ & $\$ 0.0$ & $\$ 0.0$ & $\$ 0.0$ & $\$ 0.0$ & $\$ 0.0$ & $\$ 0.0$ & $\$ 0.0$ & $\$ 0.0$ & $\$ 0.0$ \\
\hline Expenditures on Electricity, Residential & $-\$ 17.6$ & $-\$ 33.5$ & $-\$ 50.6$ & $-\$ 67.2$ & $-\$ 83.9$ & $-\$ 118.3$ & $-\$ 206.1$ & $-\$ 261.7$ & $-\$ 265.8$ & $-\$ 267.5$ \\
\hline Expenditures on Electricity, Commercial & $\$ 0.0$ & $\$ 0.0$ & $\$ 0.0$ & $\$ 0.0$ & $\$ 0.0$ & $\$ 0.0$ & $\$ 0.0$ & $\$ 0.0$ & $\$ 0.0$ & $\$ 0.0$ \\
\hline \multicolumn{11}{|l|}{ 2. State Energy Program } \\
\hline \multicolumn{11}{|l|}{903 State Energy Program } \\
\hline Investment & $\$ 164.0$ & $\$ 164.0$ & $\$ 164.0$ & $\$ 164.0$ & $\$ 164.0$ & $\$ 164.0$ & $\$ 164.0$ & $\$ 164.0$ & $\$ 164.0$ & $\$ 164.0$ \\
\hline Expenditures on Oil, Residential & $-\$ 0.9$ & $-\$ 1.8$ & $-\$ 2.8$ & $-\$ 3.8$ & $-\$ 4.7$ & $-\$ 6.7$ & $-\$ 11.9$ & $-\$ 15.3$ & $-\$ 15.8$ & $-\$ 16.3$ \\
\hline Expenditures on Oil, Commercial & $-\$ 5.2$ & $-\$ 10.4$ & $-\$ 15.4$ & $-\$ 20.9$ & $-\$ 26.4$ & $-\$ 37.6$ & $-\$ 67.7$ & $-\$ 87.7$ & $-\$ 91.6$ & $-\$ 95.7$ \\
\hline Expenditures on Natural Gas, Residential & $-\$ 0.2$ & $-\$ 0.5$ & $-\$ 0.6$ & $-\$ 0.8$ & $-\$ 1.0$ & $-\$ 1.5$ & $-\$ 2.5$ & $-\$ 3.1$ & $-\$ 3.1$ & $-\$ 3.1$ \\
\hline Expenditures on Natural Gas, Commercial & $-\$ 1.3$ & $-\$ 2.7$ & $-\$ 4.1$ & $-\$ 5.5$ & $-\$ 6.9$ & $-\$ 9.8$ & $-\$ 16.8$ & $-\$ 21.7$ & $-\$ 22.1$ & $-\$ 22.5$ \\
\hline Expenditures on Electricity, Residential & $-\$ 2.5$ & $-\$ 4.7$ & $-\$ 7.3$ & $-\$ 9.5$ & $-\$ 12.0$ & $-\$ 16.7$ & $-\$ 28.9$ & $-\$ 36.4$ & $-\$ 36.7$ & $-\$ 36.9$ \\
\hline Expenditures on Electricity, Commercial & $-\$ 17.9$ & $-\$ 34.2$ & $-\$ 50.0$ & $-\$ 64.2$ & $-\$ 79.2$ & $-\$ 107.8$ & $-\$ 185.7$ & $-\$ 237.5$ & $-\$ 240.6$ & $-\$ 244.0$ \\
\hline Change in Energy Expenditures & $-\$ 28.1$ & $-\$ 54.3$ & $-\$ 80.3$ & $-\$ 104.7$ & $-\$ 130.3$ & $-\$ 180.0$ & $-\$ 313.6$ & $-\$ 401.8$ & $-\$ 409.9$ & $-\$ 418.5$ \\
\hline
\end{tabular}




\begin{tabular}{|c|c|c|c|c|c|c|c|c|c|c|}
\hline \multirow[b]{2}{*}{ Project and Category } & \multicolumn{10}{|c|}{ Fiscal Year } \\
\hline & 2004 & 2005 & 2006 & 2007 & 2008 & 2010 & 2015 & 2020 & 2025 & 2030 \\
\hline \multicolumn{11}{|l|}{ 3. Gateway Deployment } \\
\hline \multicolumn{11}{|l|}{1332 Rebuild America } \\
\hline Investment & $\$ 212.0$ & $\$ 209.9$ & $\$ 311.0$ & $\$ 409.5$ & $\$ 404.7$ & $\$ 514.1$ & $\$ 44.1$ & $\$ 41.2$ & $\$ 40.0$ & $\$ 38.4$ \\
\hline Expenditures on Oil, Residential & $-\$ 0.2$ & $-\$ 0.4$ & $-\$ 0.6$ & $-\$ 1.0$ & $-\$ 1.4$ & $-\$ 2.2$ & $-\$ 3.1$ & $-\$ 3.1$ & $-\$ 3.1$ & $-\$ 3.2$ \\
\hline Expenditures on Oil, Commercial & $-\$ 0.2$ & $-\$ 0.4$ & $-\$ 0.7$ & $-\$ 1.0$ & $-\$ 1.4$ & $-\$ 2.2$ & $-\$ 2.9$ & $-\$ 2.6$ & $-\$ 2.5$ & $-\$ 2.4$ \\
\hline Expenditures on Natural Gas, Residential & $-\$ 3.6$ & $-\$ 6.2$ & $-\$ 10.9$ & $-\$ 17.9$ & $-\$ 23.9$ & $-\$ 37.8$ & $-\$ 50.7$ & $-\$ 49.0$ & $-\$ 48.2$ & $-\$ 47.5$ \\
\hline Expenditures on Natural Gas, Commercial & $-\$ 1.5$ & $-\$ 3.0$ & $-\$ 5.2$ & $-\$ 8.2$ & $-\$ 11.1$ & $-\$ 18.0$ & $-\$ 24.0$ & $-\$ 23.9$ & $-\$ 24.2$ & $-\$ 25.1$ \\
\hline Expenditures on Electricity, Residential & $-\$ 3.7$ & $-\$ 6.4$ & $-\$ 11.2$ & $-\$ 18.1$ & $-\$ 24.2$ & $-\$ 38.6$ & $-\$ 52.8$ & $-\$ 51.4$ & $-\$ 51.6$ & $-\$ 51.8$ \\
\hline Expenditures on Electricity, Commercial & $-\$ 2.9$ & $-\$ 5.6$ & $-\$ 9.6$ & $-\$ 14.4$ & $-\$ 19.3$ & $-\$ 30.3$ & $-\$ 43.2$ & $-\$ 46.1$ & $-\$ 48.8$ & $-\$ 52.3$ \\
\hline \multicolumn{11}{|l|}{1336 Energy Efficiency Information Outreach } \\
\hline Investment & $\$ 183.1$ & $\$ 173.3$ & $\$ 170.1$ & $\$ 172.2$ & $\$ 169.4$ & $\$ 168.2$ & $\$ 167.6$ & $\$ 175.7$ & $\$ 176.9$ & $\$ 176.7$ \\
\hline Expenditures on Oil, Residential & $-\$ 0.2$ & $-\$ 0.3$ & $-\$ 0.5$ & $-\$ 0.5$ & $-\$ 0.5$ & $-\$ 0.5$ & $-\$ 0.6$ & $-\$ 0.6$ & $-\$ 0.6$ & $-\$ 0.6$ \\
\hline Expenditures on Oil, Commercial & $-\$ 2.2$ & $-\$ 4.4$ & $-\$ 6.5$ & $-\$ 6.6$ & $-\$ 6.6$ & $-\$ 6.8$ & $-\$ 7.1$ & $-\$ 7.4$ & $-\$ 7.7$ & $-\$ 8.0$ \\
\hline Expenditures on Natural Gas, Residential & $-\$ 1.7$ & $-\$ 3.4$ & $-\$ 5.1$ & $-\$ 5.1$ & $-\$ 5.1$ & $-\$ 5.1$ & $-\$ 5.0$ & $-\$ 5.1$ & $-\$ 5.1$ & $-\$ 5.1$ \\
\hline Expenditures on Natural Gas, Commercial & $-\$ 24.7$ & $-\$ 49.8$ & $-\$ 75.2$ & $-\$ 75.9$ & $-\$ 76.3$ & $-\$ 77.3$ & $-\$ 77.3$ & $-\$ 80.3$ & $-\$ 81.7$ & $-\$ 83.2$ \\
\hline Expenditures on Electricity, Residential & $-\$ 4.2$ & $-\$ 8.2$ & $-\$ 12.4$ & $-\$ 12.3$ & $-\$ 12.3$ & $-\$ 12.3$ & $-\$ 12.4$ & $-\$ 12.5$ & $-\$ 12.5$ & $-\$ 12.6$ \\
\hline Expenditures on Electricity, Commercial & $-\$ 69.5$ & $-\$ 133.4$ & $-\$ 195.0$ & $-\$ 188.1$ & $-\$ 185.5$ & $-\$ 180.2$ & $-\$ 181.2$ & $-\$ 185.3$ & $-\$ 187.7$ & $-\$ 190.4$ \\
\hline Change in Energy Expenditures & $-\$ 102.5$ & $-\$ 199.5$ & $-\$ 294.7$ & $-\$ 288.5$ & $-\$ 286.4$ & $-\$ 282.2$ & $-\$ 283.5$ & $-\$ 291.0$ & $-\$ 295.3$ & $-\$ 299.9$ \\
\hline \multicolumn{11}{|l|}{1338 Building Codes Training and Assistance } \\
\hline
\end{tabular}




\begin{tabular}{|c|c|c|c|c|c|c|c|c|c|c|}
\hline \multirow[b]{2}{*}{ Project and Category } & \multicolumn{10}{|c|}{ Fiscal Year } \\
\hline & 2004 & 2005 & 2006 & 2007 & 2008 & 2010 & 2015 & 2020 & 2025 & 2030 \\
\hline Expenditures on Oil, Commercial & $\$ 0.0$ & $\$ 0.0$ & $\$ 0.0$ & $\$ 0.0$ & $\$ 0.0$ & $\$ 0.0$ & $\$ 0.0$ & $\$ 0.0$ & $\$ 0.0$ & $\$ 0.0$ \\
\hline Expenditures on Natural Gas, Residential & $-\$ 3.6$ & $-\$ 8.2$ & $-\$ 13.8$ & $-\$ 23.0$ & $-\$ 37.1$ & $-\$ 78.8$ & $-\$ 230.2$ & $-\$ 378.9$ & $-\$ 521.8$ & $-\$ 664.3$ \\
\hline Expenditures on Natural Gas, Commercial & $\$ 1.5$ & $\$ 5.6$ & $\$ 12.1$ & $\$ 19.4$ & $\$ 26.1$ & $\$ 36.6$ & $\$ 40.7$ & $\$ 35.9$ & $\$ 26.0$ & $\$ 16.3$ \\
\hline Expenditures on Electricity, Residential & $-\$ 6.4$ & $-\$ 13.5$ & $-\$ 21.6$ & $-\$ 35.5$ & $-\$ 57.7$ & $-\$ 127.8$ & $-\$ 402.9$ & $-\$ 681.7$ & $-\$ 957.4$ & $-\$ 1,233.2$ \\
\hline Expenditures on Electricity, Commercial & $-\$ 26.3$ & $-\$ 64.8$ & $-\$ 114.4$ & $-\$ 164.5$ & $-\$ 215.6$ & $-\$ 393.7$ & $-\$ 1,105.1$ & $-\$ 1,831.8$ & $-\$ 2,387.1$ & $-\$ 2,889.6$ \\
\hline Change in Energy Expenditures & $-\$ 35.7$ & $-\$ 82.8$ & $-\$ 141.0$ & $-\$ 208.8$ & $-\$ 292.6$ & $-\$ 580.8$ & $-\$ 1,745.7$ & $-\$ 2,933.5$ & $-\$ 3,947.1$ & $-\$ 4,908.2$ \\
\hline 422 Energy Star & \multicolumn{10}{|c|}{ Details in $4221-4228$} \\
\hline \multicolumn{11}{|l|}{4221 Energy Star: Clothes Washers } \\
\hline Investment & $\$ 295.3$ & $\$ 342.0$ & $\$ 346.7$ & $\$ 350.8$ & $\$ 351.4$ & $\$ 356.9$ & $\$ 429.3$ & $\$ 450.7$ & $\$ 473.2$ & $\$ 496.8$ \\
\hline Expenditures on Oil, Commercial & $\$ 0.0$ & $\$ 0.0$ & $\$ 0.0$ & $\$ 0.0$ & $\$ 0.0$ & $\$ 0.0$ & $\$ 0.0$ & $\$ 0.0$ & $\$ 0.0$ & $\$ 0.0$ \\
\hline Expenditures on Natural Gas, Residential & $-\$ 35.8$ & $-\$ 48.5$ & $-\$ 61.4$ & $-\$ 74.6$ & $-\$ 88.0$ & $-\$ 113.9$ & $-\$ 162.4$ & $-\$ 216.4$ & $-\$ 271.8$ & $-\$ 331.0$ \\
\hline Expenditures on Natural Gas, Commercial & $\$ 0.0$ & $\$ 0.0$ & $\$ 0.0$ & $\$ 0.0$ & $\$ 0.0$ & $\$ 0.0$ & $\$ 0.0$ & $\$ 0.0$ & $\$ 0.0$ & $\$ 0.0$ \\
\hline Expenditures on Electricity, Residential & $-\$ 64.9$ & $-\$ 84.2$ & $-\$ 106.0$ & $-\$ 126.6$ & $-\$ 148.3$ & $-\$ 191.1$ & $-\$ 270.6$ & $-\$ 340.6$ & $-\$ 418.0$ & $-\$ 504.3$ \\
\hline Expenditures on Electricity, Commercial & $\$ 0.0$ & $\$ 0.0$ & $\$ 0.0$ & $\$ 0.0$ & $\$ 0.0$ & $\$ 0.0$ & $\$ 0.0$ & $\$ 0.0$ & $\$ 0.0$ & $\$ 0.0$ \\
\hline Change in Energy Expenditures & $-\$ 107.3$ & $-\$ 141.5$ & $-\$ 178.3$ & $-\$ 214.6$ & $-\$ 251.9$ & $-\$ 325.0$ & $-\$ 460.8$ & $-\$ 591.4$ & $-\$ 730.9$ & $-\$ 883.2$ \\
\hline \multicolumn{11}{|l|}{4223 Energy Star: Refrigerators } \\
\hline Investment & $\$ 81.4$ & $\$ 193.9$ & $\$ 276.7$ & $\$ 372.3$ & $\$ 375.7$ & $\$ 386.4$ & $\$ 416.0$ & $\$ 432.0$ & $\$ 448.5$ & $\$ 465.5$ \\
\hline Expenditures on Oil, Residential & $\$ 0.0$ & $\$ 0.0$ & $\$ 0.0$ & $\$ 0.0$ & $\$ 0.0$ & $\$ 0.0$ & $\$ 0.0$ & $\$ 0.0$ & $\$ 0.0$ & $\$ 0.0$ \\
\hline Expenditures on Oil, Commercial & $\$ 0.0$ & $\$ 0.0$ & $\$ 0.0$ & $\$ 0.0$ & $\$ 0.0$ & $\$ 0.0$ & $\$ 0.0$ & $\$ 0.0$ & $\$ 0.0$ & $\$ 0.0$ \\
\hline
\end{tabular}




\begin{tabular}{|c|c|c|c|c|c|c|c|c|c|c|}
\hline \multirow[b]{2}{*}{ Project and Category } & \multicolumn{10}{|c|}{ Fiscal Year } \\
\hline & 2004 & 2005 & 2006 & 2007 & 2008 & 2010 & 2015 & 2020 & 2025 & 2030 \\
\hline Expenditures on Electricity, Residential & $-\$ 3.1$ & $-\$ 7.7$ & $-\$ 15.4$ & $-\$ 25.2$ & $-\$ 35.0$ & $-\$ 54.9$ & $-\$ 103.7$ & $-\$ 142.4$ & $-\$ 186.8$ & $-\$ 238.6$ \\
\hline Expenditures on Electricity, Commercial & $\$ 0.0$ & $\$ 0.0$ & $\$ 0.0$ & $\$ 0.0$ & $\$ 0.0$ & $\$ 0.0$ & $\$ 0.0$ & $\$ 0.0$ & $\$ 0.0$ & $\$ 0.0$ \\
\hline Change in Energy Expenditures & $-\$ 3.1$ & $-\$ 7.7$ & $-\$ 15.4$ & $-\$ 25.2$ & $-\$ 35.0$ & $-\$ 54.9$ & $-\$ 103.7$ & $-\$ 142.4$ & $-\$ 186.8$ & $-\$ 238.6$ \\
\hline \multicolumn{11}{|l|}{4226 Energy Star: Electric Water Heaters } \\
\hline Investment & $\$ 9.2$ & $\$ 17.5$ & $\$ 31.8$ & $\$ 54.1$ & $\$ 91.7$ & $\$ 164.1$ & $\$ 151.1$ & $\$ 153.2$ & $\$ 155.2$ & $\$ 157.3$ \\
\hline Expenditures on Oil, Residential & $\$ 0.0$ & $\$ 0.0$ & $\$ 0.0$ & $\$ 0.0$ & $\$ 0.0$ & $\$ 0.0$ & $\$ 0.0$ & $\$ 0.0$ & $\$ 0.0$ & $\$ 0.0$ \\
\hline Expenditures on Oil, Commercial & $\$ 0.0$ & $\$ 0.0$ & $\$ 0.0$ & $\$ 0.0$ & $\$ 0.0$ & $\$ 0.0$ & $\$ 0.0$ & $\$ 0.0$ & $\$ 0.0$ & $\$ 0.0$ \\
\hline Expenditures on Natural Gas, Residential & $\$ 0.0$ & $\$ 0.0$ & $\$ 0.0$ & $\$ 0.0$ & $\$ 0.0$ & $\$ 0.0$ & $\$ 0.0$ & $\$ 0.0$ & $\$ 0.0$ & $\$ 0.0$ \\
\hline Expenditures on Natural Gas, Commercial & $\$ 0.0$ & $\$ 0.0$ & $\$ 0.0$ & $\$ 0.0$ & $\$ 0.0$ & $\$ 0.0$ & $\$ 0.0$ & $\$ 0.0$ & $\$ 0.0$ & $\$ 0.0$ \\
\hline Expenditures on Electricity, Commercial & $\$ 0.0$ & $\$ 0.0$ & $\$ 0.0$ & $\$ 0.0$ & $\$ 0.0$ & $\$ 0.0$ & $\$ 0.0$ & $\$ 0.0$ & $\$ 0.0$ & $\$ 0.0$ \\
\hline Change in Energy Expenditures & $-\$ 0.8$ & $-\$ 4.0$ & $-\$ 9.3$ & $-\$ 19.7$ & $-\$ 40.7$ & $-\$ 122.0$ & $-\$ 340.6$ & $-\$ 606.1$ & $-\$ 917.2$ & $-\$ 1,276.5$ \\
\hline \multicolumn{11}{|l|}{4225 Energy Star: Gas Water Heaters } \\
\hline Investment & $\$ 0.0$ & $\$ 10.6$ & $\$ 17.8$ & $\$ 26.5$ & $\$ 37.1$ & $\$ 50.4$ & $\$ 104.9$ & $\$ 113.3$ & $\$ 122.0$ & $\$ 131.2$ \\
\hline Expenditures on Oil, Residential & $\$ 0.0$ & $\$ 0.0$ & $\$ 0.0$ & $\$ 0.0$ & $\$ 0.0$ & $\$ 0.0$ & $\$ 0.0$ & $\$ 0.0$ & $\$ 0.0$ & $\$ 0.0$ \\
\hline Expenditures on Oil, Commercial & $\$ 0.0$ & $\$ 0.0$ & $\$ 0.0$ & $\$ 0.0$ & $\$ 0.0$ & $\$ 0.0$ & $\$ 0.0$ & $\$ 0.0$ & $\$ 0.0$ & $\$ 0.0$ \\
\hline Expenditures on Natural Gas, Residential & $\$ 0.0$ & $-\$ 0.5$ & $-\$ 1.7$ & $-\$ 3.2$ & $-\$ 5.3$ & $-\$ 11.0$ & $-\$ 31.4$ & $-\$ 78.1$ & $-\$ 129.2$ & $-\$ 185.1$ \\
\hline Expenditures on Natural Gas, Commercial & $\$ 0.0$ & $\$ 0.0$ & $\$ 0.0$ & $\$ 0.0$ & $\$ 0.0$ & $\$ 0.0$ & $\$ 0.0$ & $\$ 0.0$ & $\$ 0.0$ & $\$ 0.0$ \\
\hline
\end{tabular}




\begin{tabular}{|c|c|c|c|c|c|c|c|c|c|c|}
\hline \multirow[b]{2}{*}{ Project and Category } & \multicolumn{10}{|c|}{ Fiscal Year } \\
\hline & 2004 & 2005 & 2006 & 2007 & 2008 & 2010 & 2015 & 2020 & 2025 & 2030 \\
\hline Change in Energy Expenditures & $\$ 0.0$ & $-\$ 0.5$ & $-\$ 1.7$ & $-\$ 3.2$ & $-\$ 5.3$ & $-\$ 11.0$ & $-\$ 31.4$ & $-\$ 78.1$ & $-\$ 129.2$ & $-\$ 185.1$ \\
\hline \multicolumn{11}{|l|}{4224 Energy Star: Room Air Conditioners } \\
\hline Investment & $\$ 243.3$ & $\$ 375.6$ & $\$ 377.1$ & $\$ 379.2$ & $\$ 372.3$ & $\$ 363.9$ & $\$ 430.7$ & $\$ 448.2$ & $\$ 466.4$ & $\$ 485.2$ \\
\hline Expenditures on Oil, Residential & $\$ 0.0$ & $\$ 0.0$ & $\$ 0.0$ & $\$ 0.0$ & $\$ 0.0$ & $\$ 0.0$ & $\$ 0.0$ & $\$ 0.0$ & $\$ 0.0$ & $\$ 0.0$ \\
\hline Expenditures on Oil, Commercial & $\$ 0.0$ & $\$ 0.0$ & $\$ 0.0$ & $\$ 0.0$ & $\$ 0.0$ & $\$ 0.0$ & $\$ 0.0$ & $\$ 0.0$ & $\$ 0.0$ & $\$ 0.0$ \\
\hline Expenditures on Natural Gas, Residential & $\$ 0.0$ & $\$ 0.0$ & $\$ 0.0$ & $\$ 0.0$ & $\$ 0.0$ & $\$ 0.0$ & $\$ 0.0$ & $\$ 0.0$ & $\$ 0.0$ & $\$ 0.0$ \\
\hline Expenditures on Natural Gas, Commercial & $\$ 0.0$ & $\$ 0.0$ & $\$ 0.0$ & $\$ 0.0$ & $\$ 0.0$ & $\$ 0.0$ & $\$ 0.0$ & $\$ 0.0$ & $\$ 0.0$ & $\$ 0.0$ \\
\hline Expenditures on Electricity, Residential & $-\$ 2.5$ & $-\$ 4.5$ & $-\$ 6.8$ & $-\$ 8.2$ & $-\$ 10.5$ & $-\$ 14.0$ & $-\$ 24.3$ & $-\$ 34.4$ & $-\$ 45.6$ & $-\$ 58.9$ \\
\hline Expenditures on Electricity, Commercial & $\$ 0.0$ & $\$ 0.0$ & $\$ 0.0$ & $\$ 0.0$ & $\$ 0.0$ & $\$ 0.0$ & $\$ 0.0$ & $\$ 0.0$ & $\$ 0.0$ & $\$ 0.0$ \\
\hline \multicolumn{11}{|l|}{4228 Energy Star: CFLs } \\
\hline Investment & $\$ 23.2$ & $\$ 29.2$ & $\$ 30.5$ & $\$ 29.5$ & $\$ 23.8$ & $\$ 26.3$ & $-\$ 143.7$ & $-\$ 683.4$ & $-\$ 1,553.5$ & $-\$ 2,502.6$ \\
\hline Expenditures on Oil, Residential & $\$ 0.0$ & $\$ 0.0$ & $\$ 0.0$ & $\$ 0.0$ & $\$ 0.0$ & $\$ 0.0$ & $\$ 0.4$ & $\$ 1.4$ & $\$ 2.1$ & $\$ 2.2$ \\
\hline Expenditures on Oil, Commercial & $\$ 0.0$ & $\$ 0.0$ & $\$ 0.0$ & $\$ 0.0$ & $\$ 0.0$ & $\$ 0.0$ & $\$ 0.0$ & $\$ 0.0$ & $\$ 0.0$ & $\$ 0.0$ \\
\hline Expenditures on Natural Gas, Residential & $\$ 0.0$ & $\$ 0.0$ & $\$ 0.0$ & $\$ 0.1$ & $\$ 0.3$ & $\$ 1.0$ & $\$ 10.4$ & $\$ 39.7$ & $\$ 58.9$ & $\$ 59.9$ \\
\hline Expenditures on Natural Gas, Commercial & $\$ 0.0$ & $\$ 0.0$ & $\$ 0.0$ & $\$ 0.0$ & $\$ 0.0$ & $\$ 0.0$ & $\$ 0.0$ & $\$ 0.0$ & $\$ 0.0$ & $\$ 0.0$ \\
\hline Expenditures on Electricity, Residential & $-\$ 30.1$ & $-\$ 80.2$ & $-\$ 156.4$ & $-\$ 262.6$ & $-\$ 410.0$ & $-\$ 785.2$ & $-\$ 2,536.1$ & $-\$ 4,970.6$ & $-\$ 6,141.5$ & $-\$ 6,329.1$ \\
\hline Expenditures on Electricity, Commercial & $\$ 0.0$ & $\$ 0.0$ & $\$ 0.0$ & $\$ 0.0$ & $\$ 0.0$ & $\$ 0.0$ & $\$ 0.0$ & $\$ 0.0$ & $\$ 0.0$ & $\$ 0.0$ \\
\hline Change in Energy Expenditures & $-\$ 30.1$ & $-\$ 80.2$ & $-\$ 156.4$ & $-\$ 262.4$ & $-\$ 409.7$ & $-\$ 784.1$ & $-\$ 2,525.3$ & $-\$ 4,929.5$ & $-\$ 6,080.5$ & $-\$ 6,266.9$ \\
\hline \multicolumn{11}{|l|}{4222 Energy Star: Dishwashers } \\
\hline
\end{tabular}




\begin{tabular}{|c|c|c|c|c|c|c|c|c|c|c|}
\hline \multirow[b]{2}{*}{ Project and Category } & \multicolumn{10}{|c|}{ Fiscal Year } \\
\hline & 2004 & 2005 & 2006 & 2007 & 2008 & 2010 & 2015 & 2020 & 2025 & 2030 \\
\hline Expenditures on Oil, Commercial & $\$ 0.0$ & $\$ 0.0$ & $\$ 0.0$ & $\$ 0.0$ & $\$ 0.0$ & $\$ 0.0$ & $\$ 0.0$ & $\$ 0.0$ & $\$ 0.0$ & $\$ 0.0$ \\
\hline Expenditures on Natural Gas, Residential & $\$ 0.0$ & $\$ 0.0$ & $\$ 0.0$ & $\$ 0.0$ & $\$ 0.0$ & $\$ 0.0$ & $\$ 0.0$ & $\$ 0.0$ & $\$ 0.0$ & $\$ 0.0$ \\
\hline Expenditures on Natural Gas, Commercial & $\$ 0.0$ & $\$ 0.0$ & $\$ 0.0$ & $\$ 0.0$ & $\$ 0.0$ & $\$ 0.0$ & $\$ 0.0$ & $\$ 0.0$ & $\$ 0.0$ & $\$ 0.0$ \\
\hline Expenditures on Electricity, Residential & $-\$ 1.5$ & $-\$ 3.0$ & $-\$ 5.5$ & $-\$ 7.0$ & $-\$ 9.0$ & $-\$ 13.2$ & $-\$ 24.9$ & $-\$ 38.4$ & $-\$ 54.5$ & $-\$ 72.3$ \\
\hline Expenditures on Electricity, Commercial & $\$ 0.0$ & $\$ 0.0$ & $\$ 0.0$ & $\$ 0.0$ & $\$ 0.0$ & $\$ 0.0$ & $\$ 0.0$ & $\$ 0.0$ & $\$ 0.0$ & $\$ 0.0$ \\
\hline Change in Energy Expenditures & $-\$ 1.5$ & $-\$ 3.0$ & $-\$ 5.5$ & $-\$ 7.0$ & $-\$ 9.0$ & $-\$ 13.2$ & $-\$ 24.9$ & $-\$ 38.4$ & $-\$ 54.5$ & $-\$ 72.3$ \\
\hline \multicolumn{11}{|c|}{ Weatherization and Intergovernmental Program (DU 1-3) } \\
\hline Investment & $\$ 1,966.7$ & $\$ 2,371.7$ & $\$ 2,636.5$ & $\$ 2,919.1$ & $\$ 3,031.4$ & $\$ 3,688.7$ & $\$ 3,564.8$ & $\$ 3,025.9$ & $\$ 2,083.1$ & $\$ 1,272.3$ \\
\hline Expenditures on Oil, Residential & $-\$ 24.8$ & $-\$ 44.9$ & $-\$ 64.9$ & $-\$ 87.2$ & $-\$ 110.4$ & $-\$ 160.5$ & $-\$ 296.6$ & $-\$ 393.6$ & $-\$ 440.4$ & $-\$ 487.1$ \\
\hline Expenditures on Natural Gas, Residential & $-\$ 79.7$ & $-\$ 135.4$ & $-\$ 195.3$ & $-\$ 260.1$ & $-\$ 329.6$ & $-\$ 483.9$ & $-\$ 876.8$ & $-\$ 1,210.0$ & $-\$ 1,444.6$ & $-\$ 1,701.0$ \\
\hline Expenditures on Natural Gas, Commercial & $-\$ 26.0$ & $-\$ 50.0$ & $-\$ 72.4$ & $-\$ 70.2$ & $-\$ 68.2$ & $-\$ 68.6$ & $-\$ 77.4$ & $-\$ 90.0$ & $-\$ 102.0$ & $-\$ 114.6$ \\
\hline Expenditures on Electricity, Residential & $-\$ 137.4$ & $-\$ 249.9$ & $-\$ 402.5$ & $-\$ 592.0$ & $-\$ 843.5$ & $-\$ 1,494.2$ & $-\$ 4,003.2$ & $-\$ 7,176.1$ & $-\$ 9,087.5$ & $-\$ 10,081.7$ \\
\hline Expenditures on Electricity, Commercial & $-\$ 116.6$ & $-\$ 237.9$ & $-\$ 369.0$ & $-\$ 431.3$ & $-\$ 499.6$ & $-\$ 712.1$ & $-\$ 1,515.2$ & $-\$ 2,300.7$ & $-\$ 2,864.2$ & $-\$ 3,376.3$ \\
\hline Change in Energy Expenditures & $-\$ 392.0$ & $-\$ 733.2$ & $-\$ 1,126.7$ & $-\$ 1,469.3$ & $-\$ 1,885.7$ & $-\$ 2,965.7$ & $-\$ 6,846.9$ & $-\$ 11,268.2$ & $-\$ 14,040.5$ & $-\$ 15,866.8$ \\
\hline \multicolumn{11}{|l|}{ 4. Residential Buildings Integration } \\
\hline \multicolumn{11}{|l|}{115 Research \& Development (Building America) } \\
\hline Investment & $\$ 27.3$ & $\$ 48.2$ & $\$ 83.6$ & $\$ 87.4$ & $\$ 112.8$ & $\$ 128.0$ & $\$ 74.5$ & $\$ 26.7$ & $\$ 26.7$ & $\$ 26.7$ \\
\hline Expenditures on Oil, Residential & $-\$ 0.1$ & $-\$ 0.2$ & $-\$ 0.4$ & $-\$ 0.7$ & $-\$ 1.1$ & $-\$ 2.1$ & $-\$ 4.3$ & $-\$ 5.5$ & $-\$ 6.2$ & $-\$ 7.0$ \\
\hline Expenditures on Oil, Commercial & $\$ 0.0$ & $\$ 0.0$ & $\$ 0.0$ & $\$ 0.0$ & $\$ 0.0$ & $\$ 0.0$ & $\$ 0.0$ & $\$ 0.0$ & $\$ 0.0$ & $\$ 0.0$ \\
\hline
\end{tabular}




\begin{tabular}{|c|c|c|c|c|c|c|c|c|c|c|}
\hline \multirow[b]{2}{*}{ Project and Category } & \multicolumn{10}{|c|}{ Fiscal Year } \\
\hline & 2004 & 2005 & 2006 & 2007 & 2008 & 2010 & 2015 & 2020 & 2025 & 2030 \\
\hline Expenditures on Electricity, Residential & $-\$ 1.2$ & $-\$ 3.4$ & $-\$ 7.9$ & $-\$ 13.0$ & $-\$ 20.2$ & $-\$ 38.1$ & $-\$ 77.3$ & $-\$ 100.4$ & $-\$ 111.7$ & $-\$ 123.0$ \\
\hline Expenditures on Electricity, Commercial & $\$ 0.0$ & $\$ 0.0$ & $\$ 0.0$ & $\$ 0.0$ & $\$ 0.0$ & $\$ 0.0$ & $\$ 0.0$ & $\$ 0.0$ & $\$ 0.0$ & $\$ 0.0$ \\
\hline Change in Energy Expenditures & $-\$ 2.4$ & $-\$ 7.0$ & $-\$ 15.9$ & $-\$ 26.1$ & $-\$ 40.6$ & $-\$ 76.3$ & $-\$ 149.5$ & $-\$ 189.6$ & $-\$ 210.6$ & $-\$ 231.6$ \\
\hline \multicolumn{11}{|l|}{506 Residential Building Energy Codes } \\
\hline Investment & $\$ 0.0$ & $\$ 0.0$ & $\$ 0.0$ & $\$ 0.3$ & $\$ 2.8$ & $\$ 18.2$ & $\$ 101.4$ & $\$ 138.1$ & $\$ 148.0$ & $\$ 158.0$ \\
\hline Expenditures on Oil, Residential & $\$ 0.0$ & $\$ 0.0$ & $\$ 0.0$ & $\$ 0.0$ & $\$ 0.0$ & $-\$ 1.2$ & $-\$ 13.6$ & $-\$ 34.6$ & $-\$ 57.3$ & $-\$ 81.1$ \\
\hline Expenditures on Oil, Commercial & $\$ 0.0$ & $\$ 0.0$ & $\$ 0.0$ & $\$ 0.0$ & $\$ 0.0$ & $\$ 0.0$ & $\$ 0.0$ & $\$ 0.0$ & $\$ 0.0$ & $\$ 0.0$ \\
\hline Expenditures on Natural Gas, Residential & $\$ 0.0$ & $\$ 0.0$ & $\$ 0.0$ & $-\$ 0.1$ & $-\$ 0.4$ & $-\$ 3.8$ & $-\$ 45.5$ & $-\$ 126.7$ & $-\$ 213.5$ & $-\$ 303.8$ \\
\hline Expenditures on Natural Gas, Commercial & $\$ 0.0$ & $\$ 0.0$ & $\$ 0.0$ & $\$ 0.0$ & $\$ 0.0$ & $\$ 0.0$ & $\$ 0.0$ & $\$ 0.0$ & $\$ 0.0$ & $\$ 0.0$ \\
\hline Expenditures on Electricity, Commercial & $\$ 0.0$ & $\$ 0.0$ & $\$ 0.0$ & $\$ 0.0$ & $\$ 0.0$ & $\$ 0.0$ & $\$ 0.0$ & $\$ 0.0$ & $\$ 0.0$ & $\$ 0.0$ \\
\hline Change in Energy Expenditures & $\$ 0.0$ & $\$ 0.0$ & $\$ 0.0$ & $-\$ 0.1$ & $-\$ 0.7$ & $-\$ 6.7$ & $-\$ 82.2$ & $-\$ 227.3$ & $-\$ 387.8$ & $-\$ 560.5$ \\
\hline \multicolumn{11}{|l|}{116 Zero Energy Buildings } \\
\hline Investment & $\$ 31.5$ & $\$ 46.8$ & $\$ 64.4$ & $\$ 84.0$ & $\$ 109.8$ & $\$ 158.0$ & $\$ 262.0$ & $\$ 414.1$ & $\$ 596.6$ & $\$ 746.3$ \\
\hline Expenditures on Oil, Residential & $-\$ 0.2$ & $-\$ 0.5$ & $-\$ 1.0$ & $-\$ 1.7$ & $-\$ 2.6$ & $-\$ 6.1$ & $-\$ 25.2$ & $-\$ 60.3$ & $-\$ 115.0$ & $-\$ 190.5$ \\
\hline Expenditures on Oil, Commercial & $\$ 0.0$ & $\$ 0.0$ & $\$ 0.0$ & $\$ 0.0$ & $\$ 0.0$ & $\$ 0.0$ & $\$ 0.0$ & $\$ 0.0$ & $\$ 0.0$ & $\$ 0.0$ \\
\hline Expenditures on Natural Gas, Residential & $-\$ 0.6$ & $-\$ 1.5$ & $-\$ 3.0$ & $-\$ 5.0$ & $-\$ 8.1$ & $-\$ 18.2$ & $-\$ 71.7$ & $-\$ 170.9$ & $-\$ 316.2$ & $-\$ 508.6$ \\
\hline Expenditures on Natural Gas, Commercial & $\$ 0.0$ & $\$ 0.0$ & $\$ 0.0$ & $\$ 0.0$ & $\$ 0.0$ & $\$ 0.0$ & $\$ 0.0$ & $\$ 0.0$ & $\$ 0.0$ & $\$ 0.0$ \\
\hline Expenditures on Electricity, Residential & $-\$ 1.5$ & $-\$ 4.0$ & $-\$ 8.1$ & $-\$ 13.5$ & $-\$ 21.5$ & $-\$ 48.7$ & $-\$ 195.3$ & $-\$ 460.9$ & $-\$ 857.4$ & $-\$ 1,385.9$ \\
\hline Expenditures on Electricity, Commercial & $\$ 0.0$ & $\$ 0.0$ & $\$ 0.0$ & $\$ 0.0$ & $\$ 0.0$ & $\$ 0.0$ & $\$ 0.0$ & $\$ 0.0$ & $\$ 0.0$ & $\$ 0.0$ \\
\hline
\end{tabular}




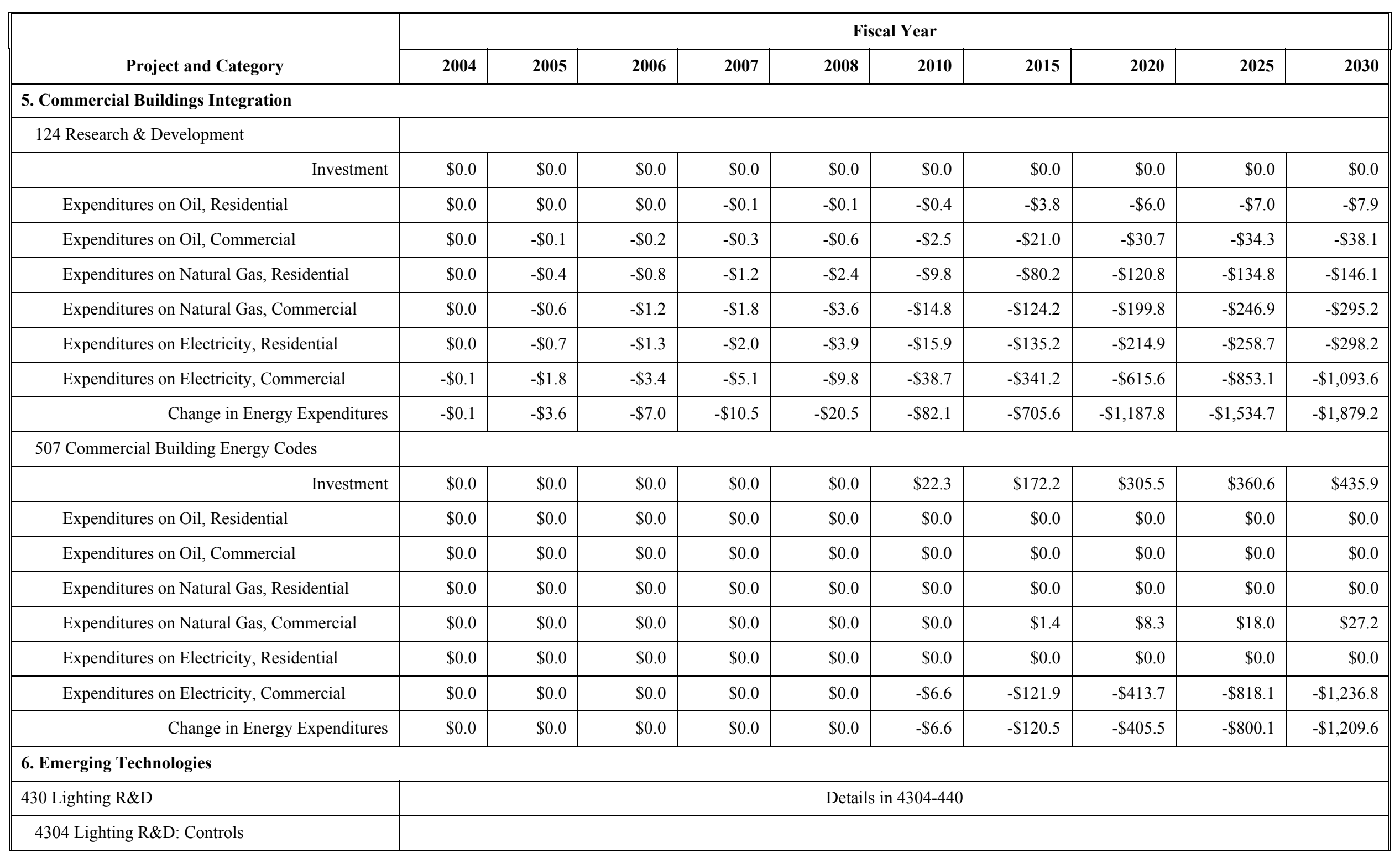




\begin{tabular}{|c|c|c|c|c|c|c|c|c|c|c|}
\hline \multirow[b]{2}{*}{ Project and Category } & \multicolumn{10}{|c|}{ Fiscal Year } \\
\hline & 2004 & 2005 & 2006 & 2007 & 2008 & 2010 & 2015 & 2020 & 2025 & 2030 \\
\hline Investment & $\$ 35.3$ & $\$ 28.8$ & $\$ 40.1$ & $\$ 51.3$ & $\$ 68.2$ & $\$ 93.7$ & $\$ 91.0$ & $\$ 58.2$ & $\$ 68.9$ & $\$ 66.2$ \\
\hline Expenditures on Oil, Residential & $\$ 0.0$ & $\$ 0.0$ & $\$ 0.0$ & $\$ 0.0$ & $\$ 0.0$ & $\$ 0.0$ & $\$ 0.0$ & $\$ 0.0$ & $\$ 0.0$ & $\$ 0.0$ \\
\hline Expenditures on Oil, Commercial & $\$ 0.0$ & $\$ 0.0$ & $\$ 0.0$ & $\$ 0.0$ & $\$ 0.0$ & $\$ 0.0$ & $\$ 0.0$ & $\$ 0.0$ & $\$ 0.0$ & $\$ 0.0$ \\
\hline Expenditures on Natural Gas, Residential & $\$ 0.0$ & $\$ 0.0$ & $\$ 0.0$ & $\$ 0.0$ & $\$ 0.0$ & $\$ 0.0$ & $\$ 0.0$ & $\$ 0.0$ & $\$ 0.0$ & $\$ 0.0$ \\
\hline Expenditures on Natural Gas, Commercial & $\$ 0.0$ & $\$ 0.0$ & $\$ 0.0$ & $\$ 0.0$ & $\$ 0.0$ & $\$ 0.0$ & $\$ 0.0$ & $\$ 0.0$ & $\$ 0.0$ & $\$ 0.0$ \\
\hline Expenditures on Electricity, Residential & $\$ 0.0$ & $\$ 0.0$ & $\$ 0.0$ & $\$ 0.0$ & $\$ 0.0$ & $\$ 0.0$ & $\$ 0.0$ & $\$ 0.0$ & $\$ 0.0$ & $\$ 0.0$ \\
\hline Expenditures on Electricity, Commercial & $-\$ 9.9$ & $-\$ 17.9$ & $-\$ 29.2$ & $-\$ 43.5$ & $-\$ 62.6$ & $-\$ 111.9$ & $-\$ 257.1$ & $-\$ 355.6$ & $-\$ 456.1$ & $-\$ 550.7$ \\
\hline Change in Energy Expenditures & $-\$ 9.9$ & $-\$ 17.9$ & $-\$ 29.2$ & $-\$ 43.5$ & $-\$ 62.6$ & $-\$ 111.9$ & $-\$ 257.1$ & $-\$ 355.6$ & $-\$ 456.1$ & $-\$ 550.7$ \\
\hline \multicolumn{11}{|l|}{440 Next Generation Lighting Initiative } \\
\hline Investment & $\$ 0.0$ & $\$ 0.0$ & $\$ 0.0$ & $\$ 0.0$ & $\$ 0.0$ & $\$ 0.0$ & $\$ 0.5$ & $\$ 31.6$ & $\$ 65.9$ & $\$ 103.8$ \\
\hline Expenditures on Oil, Residential & $\$ 0.0$ & $\$ 0.0$ & $\$ 0.0$ & $\$ 0.0$ & $\$ 0.0$ & $\$ 0.0$ & $\$ 0.0$ & $\$ 0.0$ & $\$ 0.0$ & $\$ 0.0$ \\
\hline Expenditures on Oil, Commercial & $\$ 0.0$ & $\$ 0.0$ & $\$ 0.0$ & $\$ 0.0$ & $\$ 0.0$ & $\$ 0.0$ & $\$ 0.0$ & $\$ 0.0$ & $\$ 0.0$ & $\$ 0.0$ \\
\hline Expenditures on Natural Gas, Residential & $\$ 0.0$ & $\$ 0.0$ & $\$ 0.0$ & $\$ 0.0$ & $\$ 0.0$ & $\$ 0.0$ & $\$ 0.0$ & $\$ 0.0$ & $\$ 0.0$ & $\$ 0.0$ \\
\hline Expenditures on Natural Gas, Commercial & $\$ 0.0$ & $\$ 0.0$ & $\$ 0.0$ & $\$ 0.0$ & $\$ 0.0$ & $\$ 0.0$ & $\$ 0.0$ & $\$ 0.0$ & $\$ 0.0$ & $\$ 0.0$ \\
\hline Expenditures on Electricity, Residential & $\$ 0.0$ & $\$ 0.0$ & $\$ 0.0$ & $\$ 0.0$ & $\$ 0.0$ & $\$ 0.0$ & $\$ 0.0$ & $\$ 0.0$ & $\$ 0.0$ & $\$ 0.0$ \\
\hline Expenditures on Electricity, Commercial & $\$ 0.0$ & $\$ 0.0$ & $\$ 0.0$ & $\$ 0.0$ & $\$ 0.0$ & $\$ 0.0$ & $\$ 0.0$ & $-\$ 398.9$ & $-\$ 887.2$ & $-\$ 1,484.4$ \\
\hline Change in Energy Expenditures & $\$ 0.0$ & $\$ 0.0$ & $\$ 0.0$ & $\$ 0.0$ & $\$ 0.0$ & $\$ 0.0$ & $\$ 0.0$ & $-\$ 398.9$ & $-\$ 887.2$ & $-\$ 1,484.4$ \\
\hline 380 Space Conditioning \& Refrigeration R\&D & \multicolumn{10}{|c|}{ Details in $3801-3804$} \\
\hline \multicolumn{11}{|l|}{$\begin{array}{l}3801 \text { Refrigeration R\&D: Res. HVAC Dist. } \\
\text { System }\end{array}$} \\
\hline Investment & $\$ 69.1$ & $\$ 104.9$ & $\$ 152.1$ & $\$ 214.9$ & $\$ 304.0$ & $\$ 540.5$ & $\$ 726.4$ & $\$ 248.0$ & $\$ 299.8$ & $\$ 313.9$ \\
\hline Expenditures on Oil, Residential & $-\$ 0.3$ & $-\$ 0.7$ & $-\$ 1.2$ & $-\$ 2.0$ & $-\$ 3.2$ & $-\$ 6.8$ & $-\$ 21.1$ & $-\$ 24.0$ & $-\$ 13.4$ & $-\$ 8.7$ \\
\hline
\end{tabular}




\begin{tabular}{|c|c|c|c|c|c|c|c|c|c|c|}
\hline \multirow[b]{2}{*}{ Project and Category } & \multicolumn{10}{|c|}{ Fiscal Year } \\
\hline & 2004 & 2005 & 2006 & 2007 & 2008 & 2010 & 2015 & 2020 & 2025 & 2030 \\
\hline Expenditures on Oil, Commercial & $\$ 0.0$ & $\$ 0.0$ & $\$ 0.0$ & $\$ 0.0$ & $\$ 0.0$ & $\$ 0.0$ & $\$ 0.0$ & $\$ 0.0$ & $\$ 0.0$ & $\$ 0.0$ \\
\hline Expenditures on Natural Gas, Residential & $-\$ 6.2$ & $-\$ 15.4$ & $-\$ 28.4$ & $-\$ 46.7$ & $-\$ 72.2$ & $-\$ 151.0$ & $-\$ 444.0$ & $-\$ 493.5$ & $-\$ 256.9$ & $-\$ 147.9$ \\
\hline Expenditures on Natural Gas, Commercial & $\$ 0.0$ & $\$ 0.0$ & $\$ 0.0$ & $\$ 0.0$ & $\$ 0.0$ & $\$ 0.0$ & $\$ 0.0$ & $\$ 0.0$ & $\$ 0.0$ & $\$ 0.0$ \\
\hline Expenditures on Electricity, Residential & $-\$ 5.8$ & $-\$ 14.2$ & $-\$ 26.7$ & $-\$ 43.6$ & $-\$ 67.7$ & $-\$ 142.4$ & $-\$ 432.1$ & $-\$ 490.3$ & $-\$ 285.0$ & $-\$ 201.9$ \\
\hline Expenditures on Electricity, Commercial & $\$ 0.0$ & $\$ 0.0$ & $\$ 0.0$ & $\$ 0.0$ & $\$ 0.0$ & $\$ 0.0$ & $\$ 0.0$ & $\$ 0.0$ & $\$ 0.0$ & $\$ 0.0$ \\
\hline Change in Energy Expenditures & $-\$ 12.3$ & $-\$ 30.3$ & $-\$ 56.3$ & $-\$ 92.3$ & $-\$ 143.1$ & $-\$ 300.2$ & $-\$ 897.1$ & $-\$ 1,007.7$ & $-\$ 555.3$ & $-\$ 358.5$ \\
\hline \multicolumn{11}{|l|}{3802 Refrigeration R\&D: Adv. Elec HPWH } \\
\hline Investment & $\$ 0.0$ & $\$ 1.6$ & $\$ 3.8$ & $\$ 7.0$ & $\$ 11.6$ & $\$ 26.8$ & $\$ 126.3$ & $\$ 179.8$ & $\$ 118.9$ & $\$ 27.3$ \\
\hline Expenditures on Oil, Residential & $\$ 0.0$ & $\$ 0.0$ & $\$ 0.0$ & $\$ 0.0$ & $\$ 0.0$ & $\$ 0.0$ & $\$ 0.0$ & $\$ 0.0$ & $\$ 0.0$ & $\$ 0.0$ \\
\hline Expenditures on Natural Gas, Residential & $\$ 0.0$ & $\$ 0.0$ & $\$ 0.0$ & $\$ 0.0$ & $\$ 0.0$ & $\$ 0.0$ & $\$ 0.0$ & $\$ 0.0$ & $\$ 0.0$ & $\$ 0.0$ \\
\hline Expenditures on Natural Gas, Commercial & $\$ 0.0$ & $\$ 0.0$ & $\$ 0.0$ & $\$ 0.0$ & $\$ 0.0$ & $\$ 0.0$ & $\$ 0.0$ & $\$ 0.0$ & $\$ 0.0$ & $\$ 0.0$ \\
\hline Expenditures on Electricity, Residential & $\$ 0.0$ & $-\$ 0.7$ & $-\$ 2.5$ & $-\$ 5.7$ & $-\$ 11.1$ & $-\$ 31.6$ & $-\$ 206.4$ & $-\$ 545.2$ & $-\$ 691.7$ & $-\$ 442.6$ \\
\hline Expenditures on Electricity, Commercial & $\$ 0.0$ & $\$ 0.0$ & $-\$ 0.1$ & $-\$ 0.3$ & $-\$ 0.7$ & $-\$ 1.8$ & $-\$ 13.7$ & $-\$ 40.8$ & $-\$ 54.2$ & $-\$ 35.7$ \\
\hline Change in Energy Expenditures & $\$ 0.0$ & $-\$ 0.8$ & $-\$ 2.7$ & $-\$ 6.1$ & $-\$ 11.8$ & $-\$ 33.4$ & $-\$ 220.1$ & $-\$ 586.1$ & $-\$ 745.9$ & $-\$ 478.3$ \\
\hline \multicolumn{11}{|l|}{3803 Refrigeration R\&D: Commercial Refrig. } \\
\hline Investment & $\$ 7.3$ & $\$ 10.4$ & $\$ 15.1$ & $\$ 21.0$ & $\$ 30.8$ & $\$ 57.2$ & $\$ 93.3$ & $-\$ 22.1$ & $-\$ 102.0$ & $-\$ 33.3$ \\
\hline Expenditures on Oil, Residential & $\$ 0.0$ & $\$ 0.0$ & $\$ 0.0$ & $\$ 0.0$ & $\$ 0.0$ & $\$ 0.0$ & $\$ 0.0$ & $\$ 0.0$ & $\$ 0.0$ & $\$ 0.0$ \\
\hline Expenditures on Oil, Commercial & $\$ 0.0$ & $\$ 0.0$ & $\$ 0.0$ & $\$ 0.0$ & $\$ 0.0$ & $\$ 0.0$ & $\$ 0.0$ & $\$ 0.0$ & $\$ 0.0$ & $\$ 0.0$ \\
\hline Expenditures on Natural Gas, Residential & $\$ 0.0$ & $\$ 0.0$ & $\$ 0.0$ & $\$ 0.0$ & $\$ 0.0$ & $\$ 0.0$ & $\$ 0.0$ & $\$ 0.0$ & $\$ 0.0$ & $\$ 0.0$ \\
\hline
\end{tabular}




\begin{tabular}{|c|c|c|c|c|c|c|c|c|c|c|}
\hline \multirow[b]{2}{*}{ Project and Category } & \multicolumn{10}{|c|}{ Fiscal Year } \\
\hline & 2004 & 2005 & 2006 & 2007 & 2008 & 2010 & 2015 & 2020 & 2025 & 2030 \\
\hline Expenditures on Electricity, Commercial & $-\$ 2.6$ & $-\$ 6.3$ & $-\$ 11.6$ & $-\$ 19.0$ & $-\$ 29.9$ & $-\$ 65.1$ & $-\$ 229.3$ & $-\$ 285.6$ & $-\$ 135.3$ & $-\$ 26.7$ \\
\hline Change in Energy Expenditures & $-\$ 2.7$ & $-\$ 6.6$ & $-\$ 12.3$ & $-\$ 20.1$ & $-\$ 31.6$ & $-\$ 68.9$ & $-\$ 242.9$ & $-\$ 302.8$ & $-\$ 143.5$ & $-\$ 28.3$ \\
\hline \multicolumn{11}{|l|}{3804 Refrigeration R\&D: Refrigerant Meter } \\
\hline Investment & $\$ 0.0$ & $\$ 4.9$ & $\$ 12.0$ & $\$ 22.3$ & $\$ 36.8$ & $\$ 84.8$ & $\$ 353.3$ & $\$ 497.8$ & $\$ 263.2$ & $\$ 56.3$ \\
\hline Expenditures on Oil, Residential & $\$ 0.0$ & $\$ 0.0$ & $\$ 0.0$ & $\$ 0.0$ & $\$ 0.0$ & $\$ 0.0$ & $\$ 0.0$ & $\$ 0.0$ & $\$ 0.0$ & $\$ 0.0$ \\
\hline Expenditures on Oil, Commercial & $\$ 0.0$ & $\$ 0.0$ & $\$ 0.0$ & $\$ 0.0$ & $\$ 0.0$ & $\$ 0.0$ & $\$ 0.0$ & $\$ 0.0$ & $\$ 0.0$ & $\$ 0.0$ \\
\hline Expenditures on Natural Gas, Residential & $\$ 0.0$ & $\$ 0.0$ & $\$ 0.0$ & $\$ 0.0$ & $\$ 0.0$ & $\$ 0.0$ & $\$ 0.0$ & $\$ 0.0$ & $\$ 0.0$ & $\$ 0.0$ \\
\hline Expenditures on Natural Gas, Commercial & $\$ 0.0$ & $\$ 0.0$ & $\$ 0.0$ & $\$ 0.0$ & $\$ 0.0$ & $\$ 0.0$ & $\$ 0.0$ & $\$ 0.0$ & $\$ 0.0$ & $\$ 0.0$ \\
\hline Expenditures on Electricity, Residential & $\$ 0.0$ & $-\$ 1.6$ & $-\$ 5.6$ & $-\$ 12.9$ & $-\$ 24.8$ & $-\$ 70.8$ & $-\$ 419.2$ & $-\$ 1,095.9$ & $-\$ 1,355.3$ & $-\$ 801.6$ \\
\hline Change in Energy Expenditures & $\$ 0.0$ & $-\$ 2.1$ & $-\$ 7.2$ & $-\$ 16.3$ & $-\$ 31.3$ & $-\$ 88.5$ & $-\$ 527.5$ & $-\$ 1,389.1$ & $-\$ 1,716.6$ & $-\$ 1,017.7$ \\
\hline 381 Appliances \& Emerging Technologies R\&D & \multicolumn{10}{|c|}{ Details in $3811-3817$} \\
\hline \multicolumn{11}{|l|}{3811 Appliances \& Emerging Tech R\&D: HPWH } \\
\hline Investment & $\$ 34.6$ & $\$ 22.8$ & $\$ 35.0$ & $\$ 50.8$ & $\$ 69.5$ & $\$ 137.5$ & $\$ 90.9$ & $\$ 93.7$ & $\$ 96.6$ & $\$ 99.6$ \\
\hline Expenditures on Oil, Residential & $\$ 0.0$ & $\$ 0.0$ & $\$ 0.0$ & $\$ 0.0$ & $\$ 0.0$ & $\$ 0.0$ & $\$ 0.0$ & $\$ 0.0$ & $\$ 0.0$ & $\$ 0.0$ \\
\hline Expenditures on Oil, Commercial & $\$ 0.0$ & $\$ 0.0$ & $\$ 0.0$ & $\$ 0.0$ & $\$ 0.0$ & $\$ 0.0$ & $\$ 0.0$ & $\$ 0.0$ & $\$ 0.0$ & $\$ 0.0$ \\
\hline Expenditures on Natural Gas, Residential & $\$ 0.0$ & $\$ 0.0$ & $\$ 0.0$ & $\$ 0.0$ & $\$ 0.0$ & $\$ 0.0$ & $\$ 0.0$ & $\$ 0.0$ & $\$ 0.0$ & $\$ 0.0$ \\
\hline Expenditures on Natural Gas, Commercial & $\$ 0.0$ & $\$ 0.0$ & $\$ 0.0$ & $\$ 0.0$ & $\$ 0.0$ & $\$ 0.0$ & $\$ 0.0$ & $\$ 0.0$ & $\$ 0.0$ & $\$ 0.0$ \\
\hline Expenditures on Electricity, Residential & $-\$ 17.1$ & $-\$ 27.2$ & $-\$ 44.8$ & $-\$ 70.2$ & $-\$ 106.6$ & $-\$ 232.1$ & $-\$ 575.6$ & $-\$ 713.5$ & $-\$ 870.1$ & $-\$ 1,048.1$ \\
\hline Expenditures on Electricity, Commercial & $\$ 0.0$ & $\$ 0.0$ & $\$ 0.0$ & $\$ 0.0$ & $\$ 0.0$ & $\$ 0.0$ & $\$ 0.0$ & $\$ 0.0$ & $\$ 0.0$ & $\$ 0.0$ \\
\hline
\end{tabular}




\begin{tabular}{|c|c|c|c|c|c|c|c|c|c|c|}
\hline \multirow[b]{2}{*}{ Project and Category } & \multicolumn{10}{|c|}{ Fiscal Year } \\
\hline & 2004 & 2005 & 2006 & 2007 & 2008 & 2010 & 2015 & 2020 & 2025 & 2030 \\
\hline \multicolumn{11}{|l|}{3813 Appl. \& Emerg. Tech R\&D: Roof Top AC } \\
\hline Investment & $\$ 0.0$ & $\$ 13.9$ & $\$ 11.6$ & $\$ 9.9$ & $\$ 9.9$ & $\$ 8.8$ & $\$ 9.0$ & $\$ 8.6$ & $\$ 8.2$ & $\$ 7.8$ \\
\hline Expenditures on Oil, Residential & $\$ 0.0$ & $\$ 0.0$ & $\$ 0.0$ & $\$ 0.0$ & $\$ 0.0$ & $\$ 0.0$ & $\$ 0.0$ & $\$ 0.0$ & $\$ 0.0$ & $\$ 0.0$ \\
\hline Expenditures on Oil, Commercial & $\$ 0.0$ & $\$ 0.0$ & $\$ 0.0$ & $\$ 0.0$ & $\$ 0.0$ & $\$ 0.0$ & $\$ 0.0$ & $\$ 0.0$ & $\$ 0.0$ & $\$ 0.0$ \\
\hline Expenditures on Natural Gas, Residential & $\$ 0.0$ & $\$ 0.0$ & $\$ 0.0$ & $\$ 0.0$ & $\$ 0.0$ & $\$ 0.0$ & $\$ 0.0$ & $\$ 0.0$ & $\$ 0.0$ & $\$ 0.0$ \\
\hline Expenditures on Natural Gas, Commercial & $\$ 0.0$ & $\$ 0.0$ & $\$ 0.0$ & $\$ 0.0$ & $\$ 0.0$ & $\$ 0.0$ & $\$ 0.0$ & $\$ 0.0$ & $\$ 0.0$ & $\$ 0.0$ \\
\hline Expenditures on Electricity, Residential & $\$ 0.0$ & $\$ 0.0$ & $\$ 0.0$ & $\$ 0.0$ & $\$ 0.0$ & $\$ 0.0$ & $\$ 0.0$ & $\$ 0.0$ & $\$ 0.0$ & $\$ 0.0$ \\
\hline Expenditures on Electricity, Commercial & $\$ 0.0$ & $-\$ 4.7$ & $-\$ 8.5$ & $-\$ 11.3$ & $-\$ 14.1$ & $-\$ 17.7$ & $-\$ 25.1$ & $-\$ 30.2$ & $-\$ 35.8$ & $-\$ 41.8$ \\
\hline Change in Energy Expenditures & $\$ 0.0$ & $-\$ 4.7$ & $-\$ 8.5$ & $-\$ 11.3$ & $-\$ 14.1$ & $-\$ 17.7$ & $-\$ 25.1$ & $-\$ 30.2$ & $-\$ 35.8$ & $-\$ 41.8$ \\
\hline \multicolumn{11}{|l|}{$\begin{array}{l}3815 \text { Appl. \& Emerg. Tech R\&D: Gas } \\
\text { Condensing WH }\end{array}$} \\
\hline Investment & $\$ 0.0$ & $\$ 2.9$ & $\$ 4.8$ & $\$ 7.6$ & $\$ 11.8$ & $\$ 22.6$ & $-\$ 1.5$ & $\$ 0.0$ & $\$ 1.6$ & $\$ 3.3$ \\
\hline Expenditures on Oil, Residential & $\$ 0.0$ & $\$ 0.0$ & $\$ 0.0$ & $\$ 0.0$ & $\$ 0.0$ & $\$ 0.0$ & $\$ 0.0$ & $\$ 0.0$ & $\$ 0.0$ & $\$ 0.0$ \\
\hline Expenditures on Oil, Commercial & $\$ 0.0$ & $\$ 0.0$ & $\$ 0.0$ & $\$ 0.0$ & $\$ 0.0$ & $\$ 0.0$ & $\$ 0.0$ & $\$ 0.0$ & $\$ 0.0$ & $\$ 0.0$ \\
\hline Expenditures on Natural Gas, Residential & $\$ 0.0$ & $-\$ 1.7$ & $-\$ 4.4$ & $-\$ 8.8$ & $-\$ 16.1$ & $-\$ 52.4$ & $-\$ 153.9$ & $-\$ 189.3$ & $-\$ 225.0$ & $-\$ 263.8$ \\
\hline Expenditures on Natural Gas, Commercial & $\$ 0.0$ & $\$ 0.0$ & $\$ 0.0$ & $\$ 0.0$ & $\$ 0.0$ & $\$ 0.0$ & $\$ 0.0$ & $\$ 0.0$ & $\$ 0.0$ & $\$ 0.0$ \\
\hline Expenditures on Electricity, Residential & $\$ 0.0$ & $\$ 0.0$ & $\$ 0.0$ & $\$ 0.0$ & $\$ 0.0$ & $\$ 0.0$ & $\$ 0.0$ & $\$ 0.0$ & $\$ 0.0$ & $\$ 0.0$ \\
\hline Expenditures on Electricity, Commercial & $\$ 0.0$ & $\$ 0.0$ & $\$ 0.0$ & $\$ 0.0$ & $\$ 0.0$ & $\$ 0.0$ & $\$ 0.0$ & $\$ 0.0$ & $\$ 0.0$ & $\$ 0.0$ \\
\hline Change in Energy Expenditures & $\$ 0.0$ & $-\$ 1.7$ & $-\$ 4.4$ & $-\$ 8.8$ & $-\$ 16.1$ & $-\$ 52.4$ & $-\$ 153.9$ & $-\$ 189.3$ & $-\$ 225.0$ & $-\$ 263.8$ \\
\hline \multicolumn{11}{|l|}{$\begin{array}{l}3816 \text { Appl. \& Emerg. Tech R\&D: Recessed Can } \\
\text { Lights }\end{array}$} \\
\hline
\end{tabular}




\begin{tabular}{|c|c|c|c|c|c|c|c|c|c|c|}
\hline \multirow[b]{2}{*}{ Project and Category } & \multicolumn{10}{|c|}{ Fiscal Year } \\
\hline & 2004 & 2005 & 2006 & 2007 & 2008 & 2010 & 2015 & 2020 & 2025 & 2030 \\
\hline Expenditures on Oil, Residential & $\$ 0.0$ & $\$ 0.0$ & $\$ 0.0$ & $\$ 0.0$ & $\$ 0.0$ & $\$ 0.0$ & $\$ 0.0$ & $\$ 0.0$ & $\$ 0.0$ & $\$ 0.0$ \\
\hline Expenditures on Oil, Commercial & $\$ 0.0$ & $\$ 0.0$ & $\$ 0.0$ & $\$ 0.0$ & $\$ 0.0$ & $\$ 0.0$ & $\$ 0.0$ & $\$ 0.0$ & $\$ 0.0$ & $\$ 0.0$ \\
\hline Expenditures on Natural Gas, Residential & $\$ 0.0$ & $\$ 0.0$ & $\$ 0.0$ & $\$ 0.0$ & $\$ 0.0$ & $\$ 0.2$ & $\$ 0.9$ & $\$ 1.0$ & $\$ 0.7$ & $\$ 0.6$ \\
\hline Expenditures on Natural Gas, Commercial & $\$ 0.0$ & $\$ 0.0$ & $\$ 0.0$ & $\$ 0.0$ & $\$ 0.0$ & $\$ 0.0$ & $\$ 0.0$ & $\$ 0.0$ & $\$ 0.0$ & $\$ 0.0$ \\
\hline Expenditures on Electricity, Residential & $-\$ 0.4$ & $-\$ 2.3$ & $-\$ 7.1$ & $-\$ 16.6$ & $-\$ 33.3$ & $-\$ 91.9$ & $-\$ 290.3$ & $-\$ 371.2$ & $-\$ 373.9$ & $-\$ 376.5$ \\
\hline Expenditures on Electricity, Commercial & $\$ 0.0$ & $\$ 0.0$ & $\$ 0.0$ & $\$ 0.0$ & $\$ 0.0$ & $\$ 0.0$ & $\$ 0.0$ & $\$ 0.0$ & $\$ 0.0$ & $\$ 0.0$ \\
\hline Change in Energy Expenditures & $-\$ 0.4$ & $-\$ 2.3$ & $-\$ 7.1$ & $-\$ 16.5$ & $-\$ 33.3$ & $-\$ 91.8$ & $-\$ 289.3$ & $-\$ 370.2$ & $-\$ 373.1$ & $-\$ 375.9$ \\
\hline \multicolumn{11}{|l|}{3817 Appl. \& Emerging Tech R\&D: R-Lamp } \\
\hline Investment & $\$ 11.1$ & $\$ 12.9$ & $\$ 11.1$ & $\$ 3.5$ & $\$ 5.6$ & $-\$ 26.0$ & $-\$ 69.0$ & $-\$ 78.9$ & $-\$ 81.4$ & $-\$ 81.7$ \\
\hline Expenditures on Oil, Commercial & $\$ 0.0$ & $\$ 0.0$ & $\$ 0.0$ & $\$ 0.0$ & $\$ 0.0$ & $\$ 0.0$ & $\$ 0.0$ & $\$ 0.0$ & $\$ 0.0$ & $\$ 0.0$ \\
\hline Expenditures on Natural Gas, Residential & $\$ 0.0$ & $\$ 0.0$ & $\$ 0.0$ & $\$ 0.0$ & $\$ 0.1$ & $\$ 0.2$ & $\$ 0.0$ & $\$ 0.0$ & $\$ 0.0$ & $\$ 0.0$ \\
\hline Expenditures on Natural Gas, Commercial & $\$ 0.0$ & $\$ 0.0$ & $\$ 0.0$ & $\$ 0.0$ & $\$ 0.0$ & $\$ 0.0$ & $\$ 0.0$ & $\$ 0.0$ & $\$ 0.0$ & $\$ 0.0$ \\
\hline Expenditures on Electricity, Residential & $-\$ 20.1$ & $-\$ 53.1$ & $-\$ 102.5$ & $-\$ 163.7$ & $-\$ 221.0$ & $-\$ 316.5$ & $-\$ 32.7$ & $\$ 0.0$ & $\$ 0.0$ & $\$ 0.0$ \\
\hline Expenditures on Electricity, Commercial & $\$ 0.0$ & $\$ 0.0$ & $\$ 0.0$ & $\$ 0.0$ & $\$ 0.0$ & $\$ 0.0$ & $\$ 0.0$ & $\$ 0.0$ & $\$ 0.0$ & $\$ 0.0$ \\
\hline Change in Energy Expenditures & $-\$ 20.1$ & $-\$ 53.1$ & $-\$ 102.5$ & $-\$ 163.6$ & $-\$ 221.0$ & $-\$ 316.4$ & $-\$ 32.7$ & $\$ 0.0$ & $\$ 0.0$ & $\$ 0.0$ \\
\hline 2111 Bldg Envelope R\&D: Window Technologies & \multicolumn{10}{|c|}{ Details in $2114-2115$} \\
\hline \multicolumn{11}{|l|}{2114 Window Tech: Electrochromic Windows } \\
\hline Investment & $\$ 143.5$ & $\$ 159.6$ & $\$ 193.3$ & $\$ 180.1$ & $\$ 210.1$ & $\$ 264.7$ & $\$ 239.0$ & $\$ 349.7$ & $\$ 387.8$ & $\$ 434.3$ \\
\hline Expenditures on Oil, Residential & $\$ 0.0$ & $\$ 0.0$ & $\$ 0.0$ & $\$ 0.0$ & $\$ 0.0$ & $\$ 0.0$ & $\$ 0.0$ & $\$ 0.0$ & $\$ 0.0$ & $\$ 0.0$ \\
\hline
\end{tabular}




\begin{tabular}{|c|c|c|c|c|c|c|c|c|c|c|}
\hline \multirow[b]{2}{*}{ Project and Category } & \multicolumn{10}{|c|}{ Fiscal Year } \\
\hline & 2004 & 2005 & 2006 & 2007 & 2008 & 2010 & 2015 & 2020 & 2025 & 2030 \\
\hline Expenditures on Natural Gas, Commercial & $\$ 6.1$ & $\$ 8.1$ & $\$ 9.9$ & $\$ 12.1$ & $\$ 13.9$ & $\$ 16.7$ & $\$ 20.1$ & $\$ 20.1$ & $\$ 19.7$ & $\$ 19.1$ \\
\hline Expenditures on Electricity, Residential & $\$ 0.0$ & $\$ 0.0$ & $\$ 0.0$ & $\$ 0.0$ & $\$ 0.0$ & $\$ 0.0$ & $\$ 0.0$ & $\$ 0.0$ & $\$ 0.0$ & $\$ 0.0$ \\
\hline Expenditures on Electricity, Commercial & $-\$ 51.8$ & $-\$ 71.7$ & $-\$ 95.3$ & $-\$ 117.7$ & $-\$ 143.2$ & $-\$ 202.3$ & $-\$ 346.8$ & $-\$ 533.2$ & $-\$ 739.4$ & $-\$ 973.0$ \\
\hline Change in Energy Expenditures & $-\$ 45.6$ & $-\$ 63.4$ & $-\$ 85.1$ & $-\$ 105.2$ & $-\$ 128.8$ & $-\$ 184.9$ & $-\$ 325.7$ & $-\$ 511.2$ & $-\$ 717.1$ & $-\$ 950.5$ \\
\hline \multicolumn{11}{|l|}{2115 Window Technologies: Superwindows } \\
\hline Investment & $\$ 471.4$ & $\$ 567.6$ & $\$ 691.0$ & $\$ 873.5$ & $\$ 1,098.1$ & $\$ 1,593.8$ & $\$ 2,527.0$ & $\$ 1,870.7$ & $\$ 2,654.6$ & $\$ 2,919.3$ \\
\hline Expenditures on Oil, Residential & $-\$ 9.0$ & $-\$ 15.4$ & $-\$ 22.5$ & $-\$ 31.6$ & $-\$ 42.6$ & $-\$ 70.1$ & $-\$ 170.5$ & $-\$ 241.8$ & $-\$ 314.1$ & $-\$ 386.3$ \\
\hline Expenditures on Oil, Commercial & $\$ 0.0$ & $\$ 0.0$ & $\$ 0.0$ & $\$ 0.0$ & $\$ 0.0$ & $\$ 0.0$ & $\$ 0.0$ & $\$ 0.0$ & $\$ 0.0$ & $\$ 0.0$ \\
\hline Expenditures on Natural Gas, Residential & $-\$ 20.9$ & $-\$ 36.1$ & $-\$ 54.2$ & $-\$ 77.6$ & $-\$ 106.6$ & $-\$ 182.5$ & $-\$ 485.9$ & $-\$ 805.8$ & $-\$ 1,143.3$ & $-\$ 1,507.8$ \\
\hline Expenditures on Natural Gas, Commercial & $\$ 0.0$ & $\$ 0.0$ & $\$ 0.0$ & $\$ 0.0$ & $\$ 0.0$ & $\$ 0.0$ & $\$ 0.0$ & $\$ 0.0$ & $\$ 0.0$ & $\$ 0.0$ \\
\hline Expenditures on Electricity, Residential & $-\$ 13.5$ & $-\$ 23.7$ & $-\$ 37.2$ & $-\$ 53.7$ & $-\$ 75.4$ & $-\$ 134.2$ & $-\$ 381.3$ & $-\$ 653.6$ & $-\$ 970.4$ & $-\$ 1,337.2$ \\
\hline Expenditures on Electricity, Commercial & $\$ 0.0$ & $\$ 0.0$ & $\$ 0.0$ & $\$ 0.0$ & $\$ 0.0$ & $\$ 0.0$ & $\$ 0.0$ & $\$ 0.0$ & $\$ 0.0$ & $\$ 0.0$ \\
\hline Change in Energy Expenditures & $-\$ 43.5$ & $-\$ 75.3$ & $-\$ 114.0$ & $-\$ 163.0$ & $-\$ 224.6$ & $-\$ 386.8$ & $-\$ 1,037.7$ & $-\$ 1,701.2$ & $-\$ 2,427.7$ & $-\$ 3,231.3$ \\
\hline $\begin{array}{l}2112 \text { Building Envelope R\&D: Thermal Insulation } \\
\text { \& Building Materials }\end{array}$ & \multicolumn{10}{|c|}{ Details in $2116-2118$} \\
\hline \multicolumn{11}{|l|}{2116 Thermal Insulation: Quick Fill Walls } \\
\hline Investment & $\$ 0.2$ & $\$ 1.5$ & $\$ 0.4$ & $\$ 1.2$ & $\$ 2.3$ & $\$ 3.5$ & $\$ 9.8$ & $\$ 13.8$ & $\$ 14.7$ & $\$ 16.0$ \\
\hline Expenditures on Oil, Residential & $\$ 0.0$ & $\$ 0.0$ & $\$ 0.0$ & $-\$ 0.1$ & $-\$ 0.2$ & $-\$ 0.3$ & $-\$ 0.9$ & $-\$ 2.0$ & $-\$ 3.2$ & $-\$ 4.3$ \\
\hline Expenditures on Oil, Commercial & $\$ 0.0$ & $\$ 0.0$ & $\$ 0.0$ & $\$ 0.0$ & $\$ 0.0$ & $\$ 0.0$ & $\$ 0.0$ & $\$ 0.0$ & $\$ 0.0$ & $\$ 0.0$ \\
\hline Expenditures on Natural Gas, Residential & $-\$ 0.1$ & $-\$ 0.4$ & $-\$ 0.5$ & $-\$ 0.9$ & $-\$ 1.4$ & $-\$ 3.1$ & $-\$ 12.6$ & $-\$ 29.4$ & $-\$ 47.8$ & $-\$ 68.1$ \\
\hline Expenditures on Natural Gas, Commercial & $\$ 0.0$ & $\$ 0.0$ & $\$ 0.0$ & $\$ 0.0$ & $\$ 0.0$ & $\$ 0.0$ & $\$ 0.0$ & $\$ 0.0$ & $\$ 0.0$ & $\$ 0.0$ \\
\hline Expenditures on Electricity, Residential & $\$ 0.0$ & $-\$ 0.3$ & $-\$ 0.3$ & $-\$ 0.3$ & $-\$ 0.5$ & $-\$ 1.0$ & $-\$ 4.5$ & $-\$ 10.1$ & $-\$ 17.1$ & $-\$ 24.9$ \\
\hline
\end{tabular}




\begin{tabular}{|c|c|c|c|c|c|c|c|c|c|c|}
\hline \multirow[b]{2}{*}{ Project and Category } & \multicolumn{10}{|c|}{ Fiscal Year } \\
\hline & 2004 & 2005 & 2006 & 2007 & 2008 & 2010 & 2015 & 2020 & 2025 & 2030 \\
\hline Expenditures on Electricity, Commercial & $\$ 0.0$ & $\$ 0.0$ & $\$ 0.0$ & $\$ 0.0$ & $\$ 0.0$ & $\$ 0.0$ & $\$ 0.0$ & $\$ 0.0$ & $\$ 0.0$ & $\$ 0.0$ \\
\hline Change in Energy Expenditures & $-\$ 0.1$ & $-\$ 0.6$ & $-\$ 0.8$ & $-\$ 1.2$ & $-\$ 2.1$ & $-\$ 4.3$ & $-\$ 18.0$ & $-\$ 41.5$ & $-\$ 68.1$ & $-\$ 97.2$ \\
\hline \multicolumn{11}{|l|}{$\begin{array}{l}2117 \text { Thermal Insulation: R30 Insulation/30 Year } \\
\text { Life Roofs }\end{array}$} \\
\hline Investment & $\$ 0.0$ & $\$ 0.0$ & $\$ 0.0$ & $\$ 0.0$ & $\$ 0.0$ & $\$ 0.0$ & $\$ 0.0$ & $\$ 0.0$ & $\$ 0.0$ & $\$ 0.0$ \\
\hline Expenditures on Oil, Residential & $\$ 0.0$ & $\$ 0.0$ & $\$ 0.0$ & $\$ 0.0$ & $\$ 0.0$ & $\$ 0.0$ & $\$ 0.0$ & $\$ 0.0$ & $\$ 0.0$ & $\$ 0.0$ \\
\hline Expenditures on Oil, Commercial & $\$ 0.0$ & $\$ 0.0$ & $\$ 0.0$ & $\$ 0.0$ & $\$ 0.0$ & $-\$ 0.1$ & $-\$ 2.3$ & $-\$ 7.4$ & $-\$ 12.5$ & $-\$ 17.7$ \\
\hline Expenditures on Natural Gas, Residential & $\$ 0.0$ & $\$ 0.0$ & $\$ 0.0$ & $\$ 0.0$ & $\$ 0.0$ & $\$ 0.0$ & $\$ 0.0$ & $\$ 0.0$ & $\$ 0.0$ & $\$ 0.0$ \\
\hline Expenditures on Natural Gas, Commercial & $\$ 0.0$ & $\$ 0.0$ & $\$ 0.0$ & $\$ 0.0$ & $\$ 0.0$ & $-\$ 1.5$ & $-\$ 21.4$ & $-\$ 75.7$ & $-\$ 133.0$ & $-\$ 194.1$ \\
\hline Expenditures on Electricity, Residential & $\$ 0.0$ & $\$ 0.0$ & $\$ 0.0$ & $\$ 0.0$ & $\$ 0.0$ & $\$ 0.0$ & $\$ 0.0$ & $\$ 0.0$ & $\$ 0.0$ & $\$ 0.0$ \\
\hline Expenditures on Electricity, Commercial & $\$ 0.0$ & $\$ 0.0$ & $\$ 0.0$ & $\$ 0.0$ & $\$ 0.0$ & $-\$ 0.4$ & $-\$ 5.5$ & $-\$ 14.1$ & $-\$ 24.1$ & $-\$ 36.1$ \\
\hline Change in Energy Expenditures & $\$ 0.0$ & $\$ 0.0$ & $\$ 0.0$ & $\$ 0.0$ & $\$ 0.0$ & $-\$ 2.0$ & $-\$ 29.2$ & $-\$ 97.1$ & $-\$ 169.5$ & $-\$ 247.9$ \\
\hline \multicolumn{11}{|l|}{2118 Thermal Insulation: Moisture/Wet Insulation } \\
\hline Investment & $\$ 13.4$ & $\$ 24.3$ & $\$ 34.9$ & $\$ 50.5$ & $\$ 67.0$ & $\$ 89.2$ & $\$ 167.4$ & $\$ 187.9$ & $\$ 207.8$ & $\$ 225.7$ \\
\hline Expenditures on Oil, Residential & $\$ 0.0$ & $-\$ 0.1$ & $-\$ 0.1$ & $-\$ 0.3$ & $-\$ 0.3$ & $-\$ 0.9$ & $-\$ 3.8$ & $-\$ 9.6$ & $-\$ 16.0$ & $-\$ 22.8$ \\
\hline Expenditures on Oil, Commercial & $\$ 0.0$ & $\$ 0.0$ & $\$ 0.0$ & $\$ 0.0$ & $\$ 0.0$ & $\$ 0.0$ & $\$ 0.0$ & $\$ 0.0$ & $\$ 0.0$ & $\$ 0.0$ \\
\hline Expenditures on Natural Gas, Residential & $-\$ 1.7$ & $-\$ 5.7$ & $-\$ 11.6$ & $-\$ 19.7$ & $-\$ 30.2$ & $-\$ 56.8$ & $-\$ 142.5$ & $-\$ 269.6$ & $-\$ 408.1$ & $-\$ 561.2$ \\
\hline Expenditures on Natural Gas, Commercial & $\$ 0.0$ & $\$ 0.0$ & $\$ 0.0$ & $\$ 0.0$ & $\$ 0.0$ & $\$ 0.0$ & $\$ 0.0$ & $\$ 0.0$ & $\$ 0.0$ & $\$ 0.0$ \\
\hline Expenditures on Electricity, Residential & $\$ 0.0$ & $-\$ 0.5$ & $-\$ 0.5$ & $-\$ 1.0$ & $-\$ 2.0$ & $-\$ 4.7$ & $-\$ 24.3$ & $-\$ 60.4$ & $-\$ 103.6$ & $-\$ 153.0$ \\
\hline Expenditures on Electricity, Commercial & $\$ 0.0$ & $\$ 0.0$ & $\$ 0.0$ & $\$ 0.0$ & $\$ 0.0$ & $\$ 0.0$ & $\$ 0.0$ & $\$ 0.0$ & $\$ 0.0$ & $\$ 0.0$ \\
\hline Change in Energy Expenditures & $-\$ 1.7$ & $-\$ 6.2$ & $-\$ 12.2$ & $-\$ 21.0$ & $-\$ 32.5$ & $-\$ 62.4$ & $-\$ 170.7$ & $-\$ 339.6$ & $-\$ 527.7$ & $-\$ 736.9$ \\
\hline
\end{tabular}




\begin{tabular}{|c|c|c|c|c|c|c|c|c|c|c|}
\hline \multirow[b]{2}{*}{ Project and Category } & \multicolumn{10}{|c|}{ Fiscal Year } \\
\hline & 2004 & 2005 & 2006 & 2007 & 2008 & 2010 & 2015 & 2020 & 2025 & 2030 \\
\hline Investment & $\$ 0.0$ & $\$ 0.0$ & $\$ 0.0$ & $\$ 0.0$ & $\$ 0.0$ & $\$ 0.0$ & $\$ 0.0$ & $\$ 0.0$ & $\$ 0.0$ & $\$ 0.0$ \\
\hline Expenditures on Oil, Residential & $\$ 0.0$ & $\$ 0.0$ & $\$ 0.0$ & $\$ 0.0$ & $\$ 0.0$ & $\$ 0.0$ & $\$ 0.0$ & $\$ 0.0$ & $\$ 0.0$ & $\$ 0.0$ \\
\hline Expenditures on Oil, Commercial & $\$ 0.0$ & $\$ 0.0$ & $\$ 0.0$ & $\$ 0.0$ & $-\$ 0.1$ & $-\$ 0.3$ & $-\$ 2.2$ & $-\$ 5.8$ & $-\$ 10.4$ & $-\$ 15.3$ \\
\hline Expenditures on Natural Gas, Residential & $\$ 0.0$ & $\$ 0.0$ & $\$ 0.0$ & $\$ 0.0$ & $\$ 0.0$ & $\$ 0.0$ & $\$ 0.0$ & $\$ 0.0$ & $\$ 0.0$ & $\$ 0.0$ \\
\hline Expenditures on Natural Gas, Commercial & $-\$ 0.1$ & $-\$ 0.2$ & $-\$ 0.4$ & $-\$ 0.8$ & $-\$ 1.2$ & $-\$ 3.6$ & $-\$ 24.7$ & $-\$ 61.3$ & $-\$ 105.7$ & $-\$ 151.3$ \\
\hline Expenditures on Electricity, Residential & $\$ 0.0$ & $\$ 0.0$ & $\$ 0.0$ & $\$ 0.0$ & $\$ 0.0$ & $\$ 0.0$ & $\$ 0.0$ & $\$ 0.0$ & $\$ 0.0$ & $\$ 0.0$ \\
\hline Expenditures on Electricity, Commercial & $-\$ 0.9$ & $-\$ 2.2$ & $-\$ 4.2$ & $-\$ 6.6$ & $-\$ 9.9$ & $-\$ 23.8$ & $-\$ 119.8$ & $-\$ 277.8$ & $-\$ 466.0$ & $-\$ 657.7$ \\
\hline Change in Energy Expenditures & $-\$ 0.9$ & $-\$ 2.4$ & $-\$ 4.6$ & $-\$ 7.4$ & $-\$ 11.2$ & $-\$ 27.6$ & $-\$ 146.7$ & $-\$ 344.9$ & $-\$ 582.1$ & $-\$ 824.3$ \\
\hline \multicolumn{11}{|l|}{ 7. Equipment Standards and Analysis } \\
\hline 603 Equipment Standards and Analysis & \multicolumn{10}{|c|}{ Details in 6039-6044 } \\
\hline \multicolumn{11}{|l|}{6043 Standards: Res Gas Furnaces/Boilers } \\
\hline Investment & $\$ 0.0$ & $\$ 0.0$ & $\$ 0.0$ & $\$ 0.0$ & $\$ 0.0$ & $\$ 25.9$ & $\$ 8.5$ & $\$ 5.7$ & $\$ 2.7$ & $-\$ 0.4$ \\
\hline Expenditures on Oil, Residential & $\$ 0.0$ & $\$ 0.0$ & $\$ 0.0$ & $\$ 0.0$ & $\$ 0.0$ & $\$ 0.0$ & $\$ 0.0$ & $\$ 0.1$ & $\$ 0.1$ & $\$ 0.2$ \\
\hline Expenditures on Oil, Commercial & $\$ 0.0$ & $\$ 0.0$ & $\$ 0.0$ & $\$ 0.0$ & $\$ 0.0$ & $\$ 0.0$ & $\$ 0.0$ & $\$ 0.0$ & $\$ 0.0$ & $\$ 0.0$ \\
\hline Expenditures on Natural Gas, Residential & $\$ 0.0$ & $\$ 0.0$ & $\$ 0.0$ & $\$ 0.0$ & $\$ 0.0$ & $-\$ 35.2$ & $-\$ 128.3$ & $-\$ 231.5$ & $-\$ 343.7$ & $-\$ 467.9$ \\
\hline Expenditures on Natural Gas, Commercial & $\$ 0.0$ & $\$ 0.0$ & $\$ 0.0$ & $\$ 0.0$ & $\$ 0.0$ & $\$ 0.0$ & $\$ 0.0$ & $\$ 0.0$ & $\$ 0.0$ & $\$ 0.0$ \\
\hline Expenditures on Electricity, Residential & $\$ 0.0$ & $\$ 0.0$ & $\$ 0.0$ & $\$ 0.0$ & $\$ 0.0$ & $\$ 0.3$ & $\$ 0.8$ & $\$ 1.3$ & $\$ 2.0$ & $\$ 3.1$ \\
\hline Expenditures on Electricity, Commercial & $\$ 0.0$ & $\$ 0.0$ & $\$ 0.0$ & $\$ 0.0$ & $\$ 0.0$ & $\$ 0.0$ & $\$ 0.0$ & $\$ 0.0$ & $\$ 0.0$ & $\$ 0.0$ \\
\hline Change in Energy Expenditures & $\$ 0.0$ & $\$ 0.0$ & $\$ 0.0$ & $\$ 0.0$ & $\$ 0.0$ & $-\$ 35.0$ & $-\$ 127.6$ & $-\$ 230.1$ & $-\$ 341.6$ & $-\$ 464.6$ \\
\hline \multicolumn{11}{|l|}{6044 Standards: EPAct Standards } \\
\hline Investment & $\$ 0.0$ & $\$ 201.9$ & $\$ 209.3$ & $\$ 192.5$ & $\$ 989.5$ & $\$ 1,055.7$ & $\$ 1,357.0$ & $\$ 1,451.2$ & $\$ 585.6$ & $\$ 618.2$ \\
\hline Expenditures on Oil, Residential & $\$ 0.0$ & $\$ 0.0$ & $\$ 0.0$ & $\$ 0.0$ & $\$ 0.0$ & $\$ 0.0$ & $\$ 0.0$ & $\$ 0.0$ & $\$ 0.0$ & $\$ 0.0$ \\
\hline
\end{tabular}




\begin{tabular}{|c|c|c|c|c|c|c|c|c|c|c|}
\hline \multirow[b]{2}{*}{ Project and Category } & \multicolumn{10}{|c|}{ Fiscal Year } \\
\hline & 2004 & 2005 & 2006 & 2007 & 2008 & 2010 & 2015 & 2020 & 2025 & 2030 \\
\hline Expenditures on Oil, Commercial & $\$ 0.0$ & $\$ 0.0$ & $\$ 0.0$ & $\$ 0.0$ & $\$ 0.0$ & $\$ 0.0$ & $\$ 0.0$ & $\$ 0.0$ & $\$ 0.0$ & $\$ 0.0$ \\
\hline Expenditures on Natural Gas, Residential & $\$ 0.0$ & $\$ 0.0$ & $\$ 0.0$ & $\$ 0.0$ & $\$ 0.0$ & $\$ 0.0$ & $\$ 0.0$ & $\$ 0.0$ & $\$ 0.0$ & $\$ 0.0$ \\
\hline Expenditures on Natural Gas, Commercial & $\$ 0.0$ & $\$ 0.0$ & $\$ 0.0$ & $\$ 0.0$ & $-\$ 5.6$ & $-\$ 18.2$ & $-\$ 49.6$ & $-\$ 84.7$ & $-\$ 114.6$ & $-\$ 145.8$ \\
\hline Expenditures on Electricity, Residential & $\$ 0.0$ & $\$ 0.0$ & $\$ 0.0$ & $\$ 0.0$ & $\$ 0.0$ & $\$ 0.0$ & $\$ 0.0$ & $\$ 0.0$ & $\$ 0.0$ & $\$ 0.0$ \\
\hline Expenditures on Electricity, Commercial & $\$ 0.0$ & $-\$ 24.6$ & $-\$ 50.0$ & $-\$ 73.4$ & $-\$ 188.3$ & $-\$ 436.3$ & $-\$ 1,218.6$ & $-\$ 2,043.9$ & $-\$ 2,364.1$ & $-\$ 2,697.0$ \\
\hline Change in Energy Expenditures & $\$ 0.0$ & $-\$ 24.6$ & $-\$ 50.0$ & $-\$ 73.4$ & $-\$ 193.8$ & $-\$ 454.5$ & $-\$ 1,268.2$ & $-\$ 2,128.5$ & $-\$ 2,478.7$ & $-\$ 2,842.8$ \\
\hline \multicolumn{11}{|l|}{6039 Standards: Distribution Transformers } \\
\hline Investment & $\$ 0.0$ & $\$ 0.0$ & $\$ 0.0$ & $\$ 0.0$ & $\$ 608.1$ & $\$ 595.0$ & $\$ 682.0$ & $\$ 798.3$ & $\$ 213.5$ & $\$ 235.8$ \\
\hline Expenditures on Oil, Residential & $\$ 0.0$ & $\$ 0.0$ & $\$ 0.0$ & $\$ 0.0$ & $\$ 0.0$ & $\$ 0.0$ & $\$ 0.0$ & $\$ 0.0$ & $\$ 0.0$ & $\$ 0.0$ \\
\hline Expenditures on Oil, Commercial & $\$ 0.0$ & $\$ 0.0$ & $\$ 0.0$ & $\$ 0.0$ & $\$ 0.0$ & $\$ 0.0$ & $\$ 0.0$ & $\$ 0.0$ & $\$ 0.0$ & $\$ 0.0$ \\
\hline Expenditures on Natural Gas, Residential & $\$ 0.0$ & $\$ 0.0$ & $\$ 0.0$ & $\$ 0.0$ & $\$ 0.0$ & $\$ 0.0$ & $\$ 0.0$ & $\$ 0.0$ & $\$ 0.0$ & $\$ 0.0$ \\
\hline Expenditures on Natural Gas, Commercial & $\$ 0.0$ & $\$ 0.0$ & $\$ 0.0$ & $\$ 0.0$ & $\$ 0.0$ & $\$ 0.0$ & $\$ 0.0$ & $\$ 0.0$ & $\$ 0.0$ & $\$ 0.0$ \\
\hline Expenditures on Electricity, Residential & $\$ 0.0$ & $\$ 0.0$ & $\$ 0.0$ & $\$ 0.0$ & $\$ 0.0$ & $\$ 0.0$ & $\$ 0.0$ & $\$ 0.0$ & $\$ 0.0$ & $\$ 0.0$ \\
\hline Expenditures on Electricity, Commercial & $\$ 0.0$ & $\$ 0.0$ & $\$ 0.0$ & $\$ 0.0$ & $-\$ 68.1$ & $-\$ 202.1$ & $-\$ 568.5$ & $-\$ 992.2$ & $-\$ 1,105.6$ & $-\$ 1,233.0$ \\
\hline Change in Energy Expenditures & $\$ 0.0$ & $\$ 0.0$ & $\$ 0.0$ & $\$ 0.0$ & $-\$ 68.1$ & $-\$ 202.1$ & $-\$ 568.5$ & $-\$ 992.2$ & $-\$ 1,105.6$ & $-\$ 1,233.0$ \\
\hline \multicolumn{11}{|l|}{ Building Technologies Program (DU 4-7) } \\
\hline Investment & $\$ 846.4$ & $\$ 1,260.5$ & $\$ 1,580.1$ & $\$ 1,890.7$ & $\$ 3,194.7$ & $\$ 4,388.6$ & $\$ 6,415.4$ & $\$ 5,737.1$ & $\$ 5,678.1$ & $\$ 6,094.1$ \\
\hline Expenditures on Oil, Residential & $-\$ 9.5$ & $-\$ 16.9$ & $-\$ 25.3$ & $-\$ 36.5$ & $-\$ 50.1$ & $-\$ 87.9$ & $-\$ 243.2$ & $-\$ 383.6$ & $-\$ 531.9$ & $-\$ 708.3$ \\
\hline Expenditures on Oil, Commercial & $\$ 0.2$ & $\$ 0.0$ & $\$ 0.0$ & $\$ 0.1$ & $-\$ 0.2$ & $-\$ 2.2$ & $-\$ 24.5$ & $-\$ 42.1$ & $-\$ 54.6$ & $-\$ 67.7$ \\
\hline Expenditures on Natural Gas, Residential & $-\$ 30.6$ & $-\$ 64.6$ & $-\$ 110.5$ & $-\$ 172.4$ & $-\$ 256.7$ & $-\$ 548.5$ & $-\$ 1,631.5$ & $-\$ 2,520.3$ & $-\$ 3,181.3$ & $-\$ 4,076.1$ \\
\hline Expenditures on Natural Gas, Commercial & $\$ 5.9$ & $\$ 7.0$ & $\$ 7.7$ & $\$ 8.4$ & $\$ 1.8$ & $-\$ 25.3$ & $-\$ 212.0$ & $-\$ 410.3$ & $-\$ 570.7$ & $-\$ 741.7$ \\
\hline Expenditures on Electricity, Residential & $-\$ 59.7$ & $-\$ 131.8$ & $-\$ 244.5$ & $-\$ 396.0$ & $-\$ 588.3$ & $-\$ 1,129.5$ & $-\$ 2,796.6$ & $-\$ 4,781.2$ & $-\$ 6,009.8$ & $-\$ 6,365.5$ \\
\hline
\end{tabular}




\begin{tabular}{|c|c|c|c|c|c|c|c|c|c|c|}
\hline \multirow[b]{2}{*}{ Project and Category } & \multicolumn{10}{|c|}{ Fiscal Year } \\
\hline & 2004 & 2005 & 2006 & 2007 & 2008 & 2010 & 2015 & 2020 & 2025 & 2030 \\
\hline Expenditures on Electricity, Commercial & $-\$ 65.2$ & $-\$ 129.6$ & $-\$ 203.9$ & $-\$ 280.5$ & $-\$ 532.8$ & $-\$ 1,124.4$ & $-\$ 3,355.6$ & $-\$ 6,294.6$ & $-\$ 8,300.3$ & $-\$ 10,282.6$ \\
\hline Change in Energy Expenditures & $-\$ 159.1$ & $-\$ 335.9$ & $-\$ 576.5$ & $-\$ 876.9$ & $-\$ 1,426.4$ & $-\$ 2,917.7$ & $-\$ 8,263.4$ & $-\$ 14,432.1$ & $-\$ 18,648.5$ & $-\$ 22,241.9$ \\
\hline \multicolumn{11}{|l|}{ Total } \\
\hline Investment & $\$ 2,813.1$ & $\$ 3,632.2$ & $\$ 4,216.6$ & $\$ 4,809.8$ & $\$ 6,226.1$ & $\$ 8,077.3$ & $\$ 9,980.2$ & $\$ 8,763.1$ & $\$ 7,761.2$ & $\$ 7,366.5$ \\
\hline Expenditures on Oil, Residential & $-\$ 34.3$ & $-\$ 61.7$ & $-\$ 90.2$ & $-\$ 123.7$ & $-\$ 160.5$ & $-\$ 248.4$ & $-\$ 539.8$ & $-\$ 777.2$ & $-\$ 972.3$ & $-\$ 1,195.4$ \\
\hline Expenditures on Oil, Commercial & $-\$ 7.4$ & $-\$ 15.2$ & $-\$ 22.5$ & $-\$ 28.5$ & $-\$ 34.6$ & $-\$ 48.8$ & $-\$ 102.2$ & $-\$ 139.9$ & $-\$ 156.3$ & $-\$ 173.8$ \\
\hline Expenditures on Natural Gas, Residential & $-\$ 110.3$ & $-\$ 200.0$ & $-\$ 305.8$ & $-\$ 432.5$ & $-\$ 586.3$ & $-\$ 1,032.3$ & $-\$ 2,508.3$ & $-\$ 3,730.3$ & $-\$ 4,625.9$ & $-\$ 5,777.1$ \\
\hline Expenditures on Natural Gas, Commercial & $-\$ 20.2$ & $-\$ 43.0$ & $-\$ 64.7$ & $-\$ 61.8$ & $-\$ 66.4$ & $-\$ 93.8$ & $-\$ 289.4$ & $-\$ 500.3$ & $-\$ 672.7$ & $-\$ 856.3$ \\
\hline Expenditures on Electricity, Residential & $-\$ 197.0$ & $-\$ 381.6$ & $-\$ 647.1$ & $-\$ 988.0$ & $-\$ 1,431.8$ & $-\$ 2,623.6$ & $-\$ 6,799.8$ & $-\$ 11,957.4$ & $-\$ 15,097.3$ & $-\$ 16,447.2$ \\
\hline Expenditures on Electricity, Commercial & $-\$ 181.8$ & $-\$ 367.5$ & $-\$ 572.8$ & $-\$ 711.8$ & $-\$ 1,032.4$ & $-\$ 1,836.5$ & $-\$ 4,870.8$ & $-\$ 8,595.3$ & $-\$ 11,164.5$ & $-\$ 13,658.8$ \\
\hline Change in Energy Expenditures & $-\$ 551.1$ & $-\$ 1,069.1$ & $-\$ 1,703.2$ & $-\$ 2,346.2$ & $-\$ 3,312.1$ & $-\$ 5,883.5$ & $-\$ 15,110.3$ & $-\$ 25,700.3$ & $-\$ 32,689.0$ & $-\$ 38,108.7$ \\
\hline
\end{tabular}


Table A.2. Allocation of EERE Buildings-Related Project Investment Costs by Sector

\begin{tabular}{|c|c|c|c|c|}
\hline Proj Code & Name & $\begin{array}{l}\text { Maximum } \\
\text { Incremental } \\
\text { Investment } \\
\text { (2002\$/year) }\end{array}$ & Percent Distribution & Comments \\
\hline 901 & $\begin{array}{l}\text { Weatherization } \\
\text { Assistance }\end{array}$ & $\$ 577.6$ & $\begin{array}{l}\text { Residential Construction } 50 \% ; 8.3 \% \text { each to } \\
\text { Millwork, Paint and Allied Products, Rubber and } \\
\text { Plastic Products, Other Glass Products, Mineral Wool, } \\
\text { Metal Doors }\end{array}$ & $\begin{array}{l}\text { Weatherization mostly involves incremental } \\
\text { expenditures on residential construction, plus } \\
\text { increases in costs of window and door } \\
\text { components and insulation. }\end{array}$ \\
\hline \multicolumn{5}{|c|}{ 2. State Energy Program } \\
\hline 903 & State Energy Program & $\$ 164.0$ & Complex & Same proportions as in all U.S. investment \\
\hline \multicolumn{5}{|c|}{ 3. Gateway Deployment } \\
\hline 1332 & Rebuild America & $\$ 514.1$ & $\begin{array}{l}\text { Commercial Construction 32.5\%; Other Non- } \\
\text { residential Construction 11.4\%;Machinery and } \\
\text { Equipment } 11.5 \% \text {; Commercial Refrigeration and } \\
\text { Heating Equipment 10\%; Wholesale and Retail Trade } \\
\text { 7.6\%, "Other" Manufacturing 5.5\%; Other Structural } \\
\text { Metal Products 5.4\%; Sheet Metal Work 5.1\%; } \\
\text { Computer and Office Equipment 4.4\%; } \\
\text { Communications Equipment 3\%; Measuring and } \\
\text { Control Devices 1.3\%; and Less than 0.5\% each on } \\
\text { Other Service Equipment, Power Equipment, Motors } \\
\text { and Generators, Relays and Industrial Controls, Other } \\
\text { Electrical Equipment, Other Fabricated Metal } \\
\text { Products, Engines and Turbines, Misc. Electric } \\
\text { Supplies. }\end{array}$ & $\begin{array}{l}\text { Approximately the same proportions as for } \\
\text { U.S. capital investment as a whole, except that } \\
\text { household and transportation equipment are } \\
\text { excluded and the extra investment is put into } \\
\text { non-residential construction. }\end{array}$ \\
\hline
\end{tabular}




\begin{tabular}{|c|c|c|c|c|}
\hline Proj Code & Name & $\begin{array}{l}\text { Maximum } \\
\text { Incremental } \\
\text { Investment } \\
\text { (2002\$/year) }\end{array}$ & Percent Distribution & Comments \\
\hline 1336 & $\begin{array}{l}\text { Energy Efficiency } \\
\text { Information Outreach }\end{array}$ & $\$ 183.1$ & $\begin{array}{l}\text { Residential Construction } 10.4 \% \text {; Commercial } \\
\text { Construction } 22.1 \% \text {; all others same as for Rebuild } \\
\text { America }\end{array}$ & $\begin{array}{l}\text { Information Outreach is a residential and } \\
\text { commercial Program. It is assumed that } 2 / 3 \text { of } \\
\text { the building construction cost increment will } \\
\text { be commercial }\end{array}$ \\
\hline 1338 & $\begin{array}{l}\text { Building Codes Training } \\
\text { and Assistance }\end{array}$ & $\$ 1,092.6$ & Same as Information Outreach & Same as Information Outreach \\
\hline 4221 & $\begin{array}{l}\text { Energy Star: Clothes } \\
\text { Washers }\end{array}$ & $\$ 496.8$ & Household Laundry Equipment $100 \%$ & $\begin{array}{l}\text { This sector is the manufacturing sector for the } \\
\text { advanced equipment }\end{array}$ \\
\hline 4223 & $\begin{array}{l}\text { Energy Star: } \\
\text { Refrigerators }\end{array}$ & $\$ 465.5$ & Household Refrigerators and Freezers $100 \%$ & $\begin{array}{l}\text { This sector is the manufacturing sector for the } \\
\text { advanced equipment }\end{array}$ \\
\hline 4226 & $\begin{array}{l}\text { Energy Star: Electric } \\
\text { Water Heaters }\end{array}$ & $\$ 164.1$ & $\begin{array}{l}\text { Household Appliances, Not Elsewhere Classified } \\
100 \%\end{array}$ & $\begin{array}{l}\text { This sector is the manufacturing sector for the } \\
\text { advanced equipment }\end{array}$ \\
\hline 4225 & $\begin{array}{l}\text { Energy Star: Gas Water } \\
\text { Heaters }\end{array}$ & $\$ 131.2$ & $\begin{array}{l}\text { Household Appliances, Not Elsewhere Classified } \\
100 \%\end{array}$ & $\begin{array}{l}\text { This sector is the manufacturing sector for the } \\
\text { advanced equipment }\end{array}$ \\
\hline 4224 & $\begin{array}{l}\text { Energy Star: Room Air } \\
\text { Conditioners }\end{array}$ & $\$ 485.2$ & $\begin{array}{l}\text { Household Appliances, Not Elsewhere Classified } \\
100 \%\end{array}$ & $\begin{array}{l}\text { This sector is the manufacturing sector for the } \\
\text { advanced equipment }\end{array}$ \\
\hline 4228 & Energy Star: CFLs & $\$ 30.5$ & $\begin{array}{l}\text { Lighting Bulbs and Tubes 50\%; Other Lighting and } \\
\text { Wiring } 50 \%\end{array}$ & $\begin{array}{l}\text { These sectors are the manufacturing sectors for } \\
\text { the advanced equipment }\end{array}$ \\
\hline 4222 & $\begin{array}{l}\text { Energy Star: } \\
\text { Dishwashers }\end{array}$ & $\$ 151.7$ & $\begin{array}{l}\text { Household Appliances, Not Elsewhere Classified } \\
100 \%\end{array}$ & $\begin{array}{l}\text { This sector is the manufacturing sector for the } \\
\text { advanced equipment }\end{array}$ \\
\hline
\end{tabular}




\begin{tabular}{|c|c|c|c|c|}
\hline Proj Code & Name & $\begin{array}{l}\text { Maximum } \\
\text { Incremental } \\
\text { Investment } \\
\text { (2002\$/year) }\end{array}$ & Percent Distribution & Comments \\
\hline \multicolumn{5}{|c|}{ 4. Residential Buildings Integration } \\
\hline 115 & $\begin{array}{l}\text { Research \& Development } \\
\text { (Building America) }\end{array}$ & $\$ 128.0$ & $\begin{array}{l}10 \% \text { each for Heating Equipment, Lighting Bulbs and } \\
\text { Tubes, and Electronic Components; } 5 \% \text { each for } \\
\text { Residential Construction, Metal Doors etc., } \\
\text { Household Cooking, Household Refrig and Freezers, } \\
\text { Household Laundry, Electric Housewares and Fans, } \\
\text { Household Vacuum Cleaners, House Appliances Not } \\
\text { Elsewhere Classified, Other Lighting and Wiring, } \\
\text { Rubber and Plastic Prodts, Other Glass Products, } \\
\text { Cement, Lime and Gypsum, and Mineral Wool. }\end{array}$ & $\begin{array}{l}\text { Incremental investment as a result of the } \\
\text { program would be expected in residential } \\
\text { construction and in the manufacturing sectors } \\
\text { making the equipment and materials that } \\
\text { would achieve energy savings }\end{array}$ \\
\hline 506 & $\begin{array}{l}\text { Residential Building } \\
\text { Energy Codes }\end{array}$ & $\$ 158.0$ & $\begin{array}{l}\text { Residential Construction } 30 \% \text {; Heating Equipment } \\
30 \% \text {; Other Glass Products (windows) } 20 \% \text {; } \\
\text { Electronic Components } 10 \% \text {; Lighting Bulbs and } \\
\text { Tubes } 5 \% \text {; Other Lighting and Wiring } 5 \% \text {. }\end{array}$ & $\begin{array}{l}\text { Incremental investment as a result of the } \\
\text { program would be expected in residential } \\
\text { construction and in the manufacturing sectors } \\
\text { making the equipment and materials that } \\
\text { would be required by codes--mostly better } \\
\text { windows and improved lighting and climate } \\
\text { and lighting control. }\end{array}$ \\
\hline 116 & Zero Energy Buildings & $\$ 746.3$ & $\begin{array}{l}\text { Electric Utilities } 25 \% \text {; Photovoltaics (SIC 3674) } \\
\text { 25\%; Other electronic components } 15 \% \text {; Windows } \\
5 \% \text {; Lighting Bulbs and Tubes 5\%; Residential } \\
\text { Construction } 25 \%\end{array}$ & $\begin{array}{l}\text { This program primarily promotes the diffusion } \\
\text { of Photovoltaics (SIC } 3674 \text { ) into the residential } \\
\text { construction sector in the near term (2010- } \\
2020 \text { ), with commercial coming on after } 2020 \text {. } \\
\text { It also promotes online, real-time load } \\
\text { monitoring by utilities. This requires } \\
\text { significant investment in instrumentation and } \\
\text { automation, PV technologies and } \\
\text { instrumentation, advanced construction } \\
\text { materials, and advanced appliances. }\end{array}$ \\
\hline
\end{tabular}




\begin{tabular}{|c|c|c|c|c|}
\hline Proj Code & Name & $\begin{array}{l}\text { Maximum } \\
\text { Incremental } \\
\text { Investment } \\
(2002 \$ / \text { year })\end{array}$ & Percent Distribution & Comments \\
\hline \multicolumn{5}{|c|}{ 5. Commercial Buildings Integration } \\
\hline 124 & Research \& Development & $\$ 0.0$ & $\begin{array}{l}\text { Commercial Construction } 10 \% \text {; Electronic } \\
\text { Components 50\%; } 15 \% \text { each for Commercial } \\
\text { Refrigeration and Heating, Service Equipment; } \\
\text { Lighting Bulbs and Tubes } 5 \% \text {; Other Lighting and } \\
\text { Wiring 5\%. }\end{array}$ & $\begin{array}{l}\text { Incremental investment as a result of the } \\
\text { program would be expected in commercial } \\
\text { construction and in the manufacturing sectors } \\
\text { making the equipment and materials that } \\
\text { would achieve energy savings. Much of the } \\
\text { improvement would be expected in climate } \\
\text { control electronics. }\end{array}$ \\
\hline 507 & $\begin{array}{l}\text { Commercial Building } \\
\text { Energy Codes }\end{array}$ & $\$ 435.9$ & $\begin{array}{l}\text { Commercial Construction } 30 \% \text {; } 20 \% \text { Other Glass } \\
\text { Products (windows); Electronic Components 10\%; } \\
15 \% \text { each for Commercial Refrigeration and Heating, } \\
\text { Service Equipment; Lighting Bulbs and Tubes 5\%; } \\
\text { Other Lighting and Wiring 5\%. }\end{array}$ & $\begin{array}{l}\text { Incremental investment as a result of the } \\
\text { program would be expected in commercial } \\
\text { construction and in the manufacturing sectors } \\
\text { making the equipment and materials that } \\
\text { would be required by codes--mostly better } \\
\text { windows and improved lighting and climate } \\
\text { and lighting control. }\end{array}$ \\
\hline \multicolumn{5}{|c|}{ 6. Emerging Technologies } \\
\hline 4304 & Lighting R\&D: Controls & $\$ 93.7$ & Electronic Components 100\% & $\begin{array}{l}\text { This sector is the manufacturing sector for the } \\
\text { advanced equipment }\end{array}$ \\
\hline 440 & $\begin{array}{l}\text { Next Generation Lighting } \\
\text { Initiative }\end{array}$ & $\$ 103.8$ & $\begin{array}{l}\text { Lighting Bulbs and Tubes 50\%; Other Lighting and } \\
\text { Wiring } 50 \%\end{array}$ & $\begin{array}{l}\text { These sectors are the manufacturing sectors for } \\
\text { the advanced (mostly solid-state) lighting } \\
\text { equipment }\end{array}$ \\
\hline 3801 & $\begin{array}{l}\text { Refrigeration R\&D: Res. } \\
\text { HVAC Dist. System }\end{array}$ & $\$ 726.4$ & Residential Construction $100 \%$ & $\begin{array}{l}\text { This program is mostly focused on } \\
\text { improvements in the construction of residential } \\
\text { buildings, including appropriate equipment } \\
\text { purchases by contractors }\end{array}$ \\
\hline
\end{tabular}




\begin{tabular}{|c|c|c|c|c|}
\hline Proj Code & Name & $\begin{array}{l}\text { Maximum } \\
\text { Incremental } \\
\text { Investment } \\
(2002 \$ / \text { year })\end{array}$ & Percent Distribution & Comments \\
\hline 3802 & $\begin{array}{l}\text { Refrigeration R\&D: Adv. } \\
\text { Elec HPWH }\end{array}$ & $\$ 179.8$ & $\begin{array}{l}\text { Household Appliances, Not Elsewhere Classified } \\
100 \%\end{array}$ & $\begin{array}{l}\text { This sector is the manufacturing sector for the } \\
\text { advanced equipment }\end{array}$ \\
\hline 3803 & $\begin{array}{l}\text { Refrigeration R\&D: } \\
\text { Commercial } \\
\text { Refrigeration }\end{array}$ & $\$ 93.3$ & $\begin{array}{l}\text { Commercial Refrigeration and Heating Equipment } \\
100 \%\end{array}$ & $\begin{array}{l}\text { This sector is the manufacturing sector for the } \\
\text { advanced equipment }\end{array}$ \\
\hline 3804 & $\begin{array}{l}\text { Refrigeration R\&D: } \\
\text { Refrigerant Meter }\end{array}$ & $\$ 497.8$ & $\begin{array}{l}\text { Commercial Refrigeration and Heating Equipment } \\
50 \% \text {; Heating Equipment } 50 \%\end{array}$ & $\begin{array}{l}\text { These sectors are the manufacturing sectors for } \\
\text { the advanced equipment }\end{array}$ \\
\hline 3811 & $\begin{array}{l}\text { Appliances \& Emerging } \\
\text { Tech R\&D: HPWH }\end{array}$ & $\$ 137.5$ & $\begin{array}{l}\text { Household Appliances, Not Elsewhere Classified } \\
100 \%\end{array}$ & $\begin{array}{l}\text { This sector is the manufacturing sector for the } \\
\text { advanced equipment }\end{array}$ \\
\hline 3813 & $\begin{array}{l}\text { Appliances \& Emerging } \\
\text { Tech R\&D: Roof Top } \\
\text { AC }\end{array}$ & $\$ 13.9$ & $\begin{array}{l}\text { Commercial Refrigeration and Heating Equipment } \\
100 \%\end{array}$ & $\begin{array}{l}\text { This sector is the manufacturing sector for the } \\
\text { advanced equipment }\end{array}$ \\
\hline 3815 & $\begin{array}{l}\text { Emerging Tech R\&D: } \\
\text { Gas Condensing WH }\end{array}$ & $\$ 22.6$ & $\begin{array}{l}\text { Household Appliances, Not Elsewhere Classified } \\
100 \%\end{array}$ & $\begin{array}{l}\text { This sector is the manufacturing sector for the } \\
\text { advanced equipment }\end{array}$ \\
\hline 3816 & $\begin{array}{l}\text { Appliances \& Emerging } \\
\text { Tech R\&D: Recessed } \\
\text { Can Lights }\end{array}$ & $\$ 83.2$ & $\begin{array}{l}\text { Lighting Bulbs and Tubes 50\%; Other Lighting and } \\
\text { Wiring 50\% }\end{array}$ & $\begin{array}{l}\text { These sectors are the manufacturing sectors for } \\
\text { the advanced equipment }\end{array}$ \\
\hline 3817 & $\begin{array}{l}\text { Appliances \& Emerging } \\
\text { Tech R\&D: R-Lamp }\end{array}$ & $\$ 12.9$ & Lighting Bulbs and Tubes $100 \%$ & $\begin{array}{l}\text { This sector is the manufacturing sector for the } \\
\text { advanced equipment }\end{array}$ \\
\hline 2114 & $\begin{array}{l}\text { Window Technologies: } \\
\text { Electrochromic Windows }\end{array}$ & $\$ 434.3$ & $\begin{array}{l}\text { Other Glass Products } 90 \% \text {; Measuring and Control } \\
\text { Devices } 10 \%\end{array}$ & $\begin{array}{l}\text { These sectors are the manufacturing sectors for } \\
\text { the advanced equipment. Most of the } \\
\text { additional cost is expected in the glass and } \\
\text { coatings. }\end{array}$ \\
\hline
\end{tabular}




\begin{tabular}{|c|c|c|c|c|}
\hline Proj Code & Name & $\begin{array}{l}\text { Maximum } \\
\text { Incremental } \\
\text { Investment } \\
(2002 \$ / \text { year })\end{array}$ & Percent Distribution & Comments \\
\hline 2115 & $\begin{array}{l}\text { Window Technologies: } \\
\text { Superwindows }\end{array}$ & $\$ 2,919.3$ & $\begin{array}{l}\text { Other Glass Products } 80 \% \text {; Other Wood Products } \\
5 \% \text {; Plastics } 5 \% \text {; Metal Doors, etc. } 5 \% \text {, Other } \\
\text { Fabricated Metal Products 5\% }\end{array}$ & $\begin{array}{l}\text { These sectors are the manufacturing sectors for } \\
\text { the advanced equipment. Most of the } \\
\text { additional cost is expected in the glass and } \\
\text { coatings, but some additional cost is expected } \\
\text { in the frames. }\end{array}$ \\
\hline 2116 & $\begin{array}{l}\text { Thermal Insulation: } \\
\text { Quick Fill Walls }\end{array}$ & $\$ 16.0$ & $\begin{array}{l}\text { Residential Construction } 75 \% \text {; Commercial } \\
\text { Construction } 25 \%\end{array}$ & $\begin{array}{l}\text { The cost is expected to be the additional cost } \\
\text { of constructing these walls. About } 75 \% \text { of the } \\
\text { market is thought to be residential. }\end{array}$ \\
\hline 2117 & $\begin{array}{l}\text { Thermal Insulation: R30 } \\
\text { Insulation/30 Year Life } \\
\text { Roofs }\end{array}$ & $\$ 0.0$ & $\begin{array}{l}\text { Commercial Construction } 75 \% \text {; Synthetic Materials } \\
25 \%\end{array}$ & $\begin{array}{l}\text { Commercial applications. Additional cost (if } \\
\text { any) is expected to be the additional } \\
\text { construction costs, plus some advanced } \\
\text { materials. }\end{array}$ \\
\hline 2118 & $\begin{array}{l}\text { Thermal Insulation: } \\
\text { Moisture/Wet Insulation }\end{array}$ & $\$ 225.7$ & Synthetic Materials $100 \%$ & $\begin{array}{l}\text { All of the cost increment is expected to be in } \\
\text { advanced materials. }\end{array}$ \\
\hline 145 & $\begin{array}{l}\text { Analysis Tools and } \\
\text { Design }\end{array}$ & $\$ 0.0$ & $\begin{array}{l}\text { Residential Construction 20\%; Heating Equipment } \\
30 \% ; 10 \% \text { each for Lighting Bulbs and Tubes and } \\
\text { Other Lighting and Wiring; } 5 \% \text { each for Household } \\
\text { Cooking, Household Refrig and Freezers, Household } \\
\text { Laundry, Electric Housewares and Fans, Household } \\
\text { Vacuum Cleaners, and Household Appliances Not } \\
\text { Elsewhere Classified. }\end{array}$ & $\begin{array}{l}\text { A broad array of sectors involved in residential } \\
\text { construction and equipment is expected to be } \\
\text { affected, with most of the impact on } \\
\text { construction, heating plant, and lighting. }\end{array}$ \\
\hline
\end{tabular}




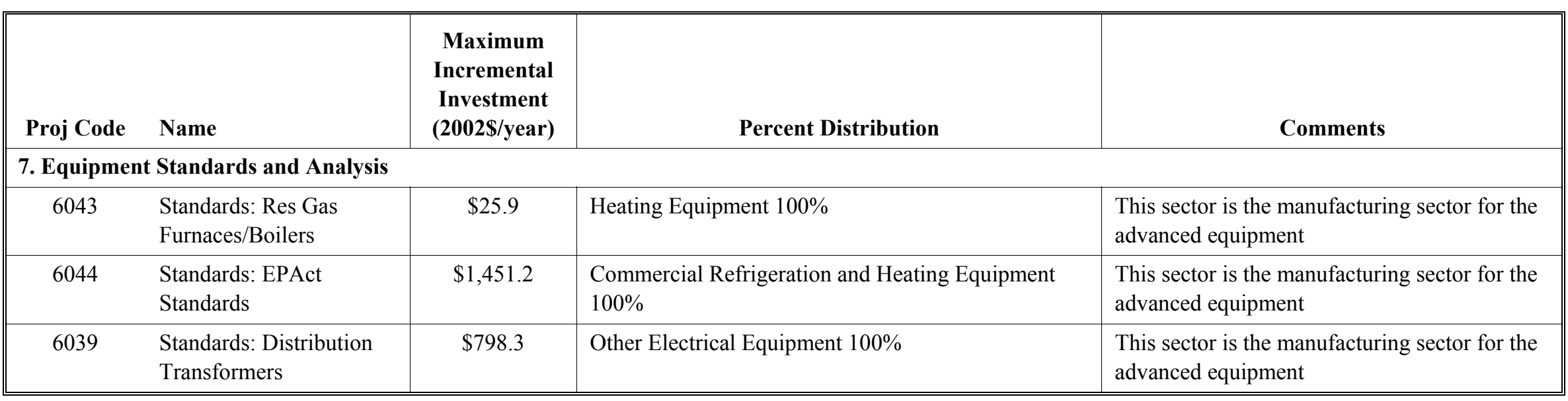




\section{Distribution}

No. of

\section{Copies}

\section{OFFSITE}

Michael McCabe (3)

U.S. Department of Energy

EERE-Building Technologies

Program (EE-2J)

1000 Independence Ave., S.W.

Washington, DC 20585

John D. Ryan

U.S. Department of Energy

EERE-Building Technologies

Program (EE-2J)

1000 Independence Ave., S.W.

Washington, DC 20585

Jim Rannells

U.S. Department of Energy

EERE-Building Technologies

Program (EE-2J)

1000 Independence Ave., S.W.

Washington, DC 20585

Ed Pollock

U.S. Department of Energy

EERE-Building Technologies

Program (EE-2J)

1000 Independence Ave., S.W.

Washington, DC 20585

Brian Card

U.S. Department of Energy

EERE-Building Technologies

Program (EE-2J)

1000 Independence Ave., S.W.

Washington, DC 20585
No. of

Copies

Qonnie Laughlin

U.S. Department of Energy

EERE-Building Technologies

Program (EE-2J)

1000 Independence Ave., S.W.

Washington, DC 20585

Bryan Berringer

U.S. Department of Energy

EERE-Building Technologies

Program (EE-2J)

1000 Independence Ave., S.W.

Washington, DC 20585

Richard Orrison

U.S. Department of Energy

EERE-Building Technologies

Program (EE-2J)

1000 Independence Ave., S.W.

Washington, DC 20585

Jim Brodrick

U.S. Department of Energy

EERE-Building Technologies

Program (EE-2J)

1000 Independence Ave., S.W.

Washington, DC 20585

John Millhone (3)

U.S. Department of Energy

EERE-Weatherization and

Intergovernmental Program (EE-2K)

1000 Independence Avenue, S.W.

Washington, DC 20585

Distr. 1 
Mark Bailey

U.S. Department of Energy

EERE-Weatherization and

Intergovernmental Program (EE-2K)

1000 Independence Avenue, S.W.

Washington, DC 20585

Phil Hayes

U.S. Department of Energy

EERE-Weatherization and

Intergovernmental Program (EE-2K)

1000 Independence Avenue, S.W.

Washington, DC 20585

Sam Baldwin

U.S. Department of Energy

EERE-Office of Planning, Budget

Formulation, and Analysis (EE-3B)

1000 Independence Avenue, S.W.

Washington, DC 20585

Darrell Beschen

U.S. Department of Energy

EERE-Office of Planning, Budget

Formulation, and Analysis (EE-3B)

1000 Independence Avenue, S.W.

Washington, DC 20585

Pat Booher

U.S. Department of Energy

EERE-Office of Planning, Budget

Formulation, and Analysis (EE-3B)

1000 Independence Avenue, S.W.

Washington, DC 20585

Jerry Dion

U.S. Department of Energy

EERE-Office of Planning, Budget

Formulation, and Analysis (EE-3B)

1000 Independence Avenue, S.W.

Washington, DC 20585
Jeff Dowd

U.S. Department of Energy

EERE-Office of Planning, Budget

Formulation, and Analysis (EE-3B)

1000 Independence Avenue, S.W.

Washington, DC 20585

Ken Friedman

U.S. Department of Energy

EERE-Office of Planning, Budget

Formulation, and Analysis (EE-3B)

1000 Independence Avenue, S.W.

Washington, DC 20585

Mike Gonzalez

U.S. Department of Energy

EERE-Office of Planning, Budget

Formulation, and Analysis (EE-3B)

1000 Independence Avenue, S.W.

Washington, DC 20585

Thomas Heavey

U.S. Department of Energy

EERE-Office of Planning, Budget

Formulation, and Analysis (EE-3B)

1000 Independence Avenue, S.W.

Washington, DC 20585

Susan Holte

U.S. Department of Energy

EERE-Office of Planning, Budget

Formulation, and Analysis (EE-3B)

1000 Independence Avenue, S.W.

Washington, DC 20585

Tien Nguyen

U.S. Department of Energy

EERE-Office of Planning, Budget

Formulation, and Analysis (EE-3B)

1000 Independence Avenue, S.W.

Washington, DC 20585

Distr. 2 
Phil Patterson

U.S. Department of Energy

EERE-Office of Planning, Budget

Formulation, and Analysis (EE-3B)

1000 Independence Avenue, S.W.

Washington, DC 20585

Peggy Podolak

U.S. Department of Energy

EERE-Office of Planning, Budget

Formulation, and Analysis (EE-3B)

1000 Independence Avenue, S.W.

Washington, DC 20585

Linda Silverman

U.S. Department of Energy

EERE-Office of Planning, Budget

Formulation, and Analysis (EE-3B)

1000 Independence Avenue, S.W.

Washington, DC 20585

Randy Steer

U.S. Department of Energy

EERE-Office of Planning, Budget

Formulation, and Analysis (EE-3B)

1000 Independence Avenue, S.W.

Washington, DC 20585

Paul Trottier

U.S. Department of Energy

EERE-Office of Planning, Budget

Formulation, and Analysis (EE-3B)

1000 Independence Avenue, S.W.

Washington, DC 20585

Phillip Tseng

U.S. Department of Energy

EERE-Office of Planning, Budget

Formulation, and Analysis (EE-3B)

1000 Independence Avenue, S.W.

Washington, DC 20585
Michael York

U.S. Department of Energy

EERE-Office of Planning, Budget

Formulation, and Analysis (EE-3B)

1000 Independence Avenue, S.W.

Washington, DC 20585

Mary Beth Zimmerman

U.S. Department of Energy

EERE-Office of Planning, Budget

Formulation, and Analysis (EE-3B)

1000 Independence Avenue, S.W.

Washington, DC 20585

Ed Barbour

Navigant Consulting

1801 K Street, NW

Suite 500

Washington, D.C. 20006

M. Singh

Argonne National Laboratory

Suite 6000

955 L'Enfant Plaza, SW

Washington, DC 20024-2112

J.G. Koomey

Environmental Energy Technology

Ernest Orlando Lawrence Berkeley

National Laboratory

1 Cyclotron Road, 90-4000

Berkeley, CA 94720

M.D. Levine

Ernest Orlando Lawrence Berkeley

National Laboratory

1 Cyclotron Road, 90-3026

Berkeley, CA 94720

Distr. 3 
T. Chan

Ernest Orlando Lawrence Berkeley

National Laboratory

1 Cyclotron Road, 90-3026

Berkeley, CA 94720

L.L. Dale

Ernest Orlando Lawrence Berkeley

National Laboratory

1 Cyclotron Road, 90-3026

Berkeley, CA 94720

Jeff Harris

Ernest Orlando Lawrence Berkeley National Laboratory

901 D Street

$9^{\text {th }}$ Floor

Washington, DC 20024-2115

Bill Baibiuch

National Renewable Energy Laboratory

901 D Street

$9^{\text {th }}$ Floor

Washington, DC 20024-2115

W. Short

National Renewable Energy Laboratory

617 Cole Boulevard, Mail Stop 2721

Golden, CO 80401-3393

M.A. Brown

Oak Ridge National Laboratory

P.O. Box 2008, Mail Stop 6186

Oak Ridge, TN 37831-6186

R. Lee

Oak Ridge National Laboratory

P.O. Box 2008, Mail Stop 6205

Oak Ridge, TN 37831-6205
H. Geller

Executive Director

American Council for an

Energy-Efficient Economy

1001 Connecticut Avenue, N.W., Suite 801

Washington, DC 20036

D. M. Nemtzow

Alliance to Save Energy $120018^{\text {th }}$ Street, N.W.

Suite 900

Washington, DC 20036

Distr. 4 
No of

Copies

\section{ONSITE}

2 DOE Richland Operations Office

D. L. Biancosino K8-50

43 Pacific Northwest National Laboratory

D. M. Anderson K5-06

R. Bartlett K5-02

D. B. Belzer K5-06

K. A. Cort K5-06

J. A. Dirks K6-10

D. B. Elliott Portland/1/OS

E. M. Fathelrahman K5-06

D. J. Hostick K5-06

B. R. Kinzey BWO

10 S. C. McDonald BWO

A. K. Nicholls BWO

L. A. Stevenson Offsite/MA/OS

J. M. Roop K5-06

L. J. Sandahl K5-06

B. F. Saffell K5-02

L. J. Sealock K5-02

10 M. J. Scott K5-06

S. A. Shankle K5-16

R.W. Schultz K6-10

T. M. Weber K5-06

5 Information Release K1-06

Distr. 5 